Claremont Colleges

Scholarship@Claremont

2012

\title{
Systematics, Biogeography and Leaf Anatomy and Architecture of Bursera subgen. Bursera (Burseraceae) in the Greater Antilles and the Bahamas
}

María Cristina Martínez-Habibe

Claremont Graduate University

\section{Recommended Citation}

Martínez-Habibe, María Cristina, "Systematics, Biogeography and Leaf Anatomy and Architecture of Bursera subgen. Bursera (Burseraceae) in the Greater Antilles and the Bahamas" (2012). CGU Theses \& Dissertations. Paper 49.

http://scholarship.claremont.edu/cgu_etd/49

DOI: $10.5642 /$ cguetd $/ 49$

This Open Access Dissertation is brought to you for free and open access by the CGU Student Scholarship at Scholarship @ Claremont. It has been accepted for inclusion in CGU Theses \& Dissertations by an authorized administrator of Scholarship @ Claremont. For more information, please contact scholarship@cuc.claremont.edu. 


\title{
Systematics, biogeography and leaf anatomy and architecture
}

of Bursera subgen. Bursera (Burseraceae) in the Greater Antilles and the Bahamas

\author{
A final project submitted to the Faculty of Claremont Graduate
}

University in partial fulfillment of the requirements for the degree of Doctor in Philosophy in the Graduate Faculty of Botany

by

\section{María Cristina Martínez-Habibe}

Claremont Graduate University

2012

(C) Copyright María Cristina Martínez-Habibe, 2012

All rights reserved. 


\section{APPROVAL OF THE REVIEW COMMITTEE}

This dissertation has been duly read, reviewed, and critiqued by the Committee listed below, which hereby approves the manuscript of María Cristina Martínez-Habibe as fulfilling the scope and quality requirements for meriting the degree of Ph.D. in Botany.

J. Travis Columbus, Ph.D., Chair

Claremont Graduate University

Professor of Botany

Lucinda A. McDade, Ph.D.

Claremont Graduate University

Chair of the Botany Department

J. Mark Porter, Ph.D.

Claremont Graduate University

Associate Professor of Botany

Douglas C. Daly, Ph.D.

The New York Botanical Garden

Director, Institute of Systematic Botany. 


\begin{abstract}
Systematics, biogeography and leaf anatomy and architecture

of Bursera subgen. Bursera (Burseraceae) in the Greater Antilles and the Bahamas

by
\end{abstract}

María Cristina Martínez-Habibe

Claremont Graduate University: 2012

This dissertation presents a comprehensive study on the origin and evolutionary relationships of the species of Bursera in Cuba, Hispaniola, Jamaica and the Bahamas. The goals of the first chapter were to test monophyly of the group, revisit a recent transfer of two species of Bursera to Commiphora, and place recently discovered mainland species using the reconstructed phylogenies. Additionally, divergence estimations using fossils were used as independent tests of several hypotheses regarding the arrival of the modern biota to the Greater Antilles and Bahamas (GAB). I conclude that all endemic taxonomic entities of the genus in this region belong to Bursera subgen. Bursera but that two separate lineages colonized the GAB via dispersal. The genus diversified during the Middle Miocene to Pliocene, and the data corroborate several paleogeographic events during that interval. The second chapter presents informative characters from leaf anatomy and leaf architecture for the 14 endemic species of Bursera distributed in the GAB. There is evidence for some evolutionary tendencies in the group, among them a trend toward small, simple, amphistomatic and unifacial leaves, character states for which ecological correlates can now be studied. Morphological and anatomical evidence corroborates phylogenetic results in suggesting 
that a population of B. glauca in Cuba is a new species. Finally, the third chapter constitutes the first taxonomic account and description of all known endemic species of Bursera in the region and reflects the results of the previous chapters. The primary results are as follows: (1) a new species from eastern Cuba, B. yaterensis, is described; (2) five species of Commiphora are returned to Bursera; (3) B. nashii is treated as conspecific with B. glauca; and (4) B. ovata is treated as conspecific with $B$. trinitensis. A dichotomous key is provided using mostly vegetative characters due to the frequent lack of adequate reproductive material and the relative uniformity of most floral and fruit characters. Each species description includes leaf architecture (morphology and venation pattern) and anatomy, introducing characters that could and should be used for describing and distinguishing other Bursera in Meso- and South America as well as for African Commiphora. 


\section{Dedication}

To my beloved husband Iohann Sanmartín and our three children,

Juana Isabel, Sofía and Simón. You are the best thing in my life.

To my parents, Orlando Martínez and Guadalupe Habibe,

who instilled in me a love for science. Thanks for being there my whole life

and your endless love.

To my California family: Susana and Alberto; Alfonso, Mercedes and Mariana, your unconditional support and trust made this dream come true. 


\section{Acknowledgments}

I specially thank my excellent advisor, J. Travis Columbus for all his support and his encouragement to pursue a doctoral degree at RSABG. Thanks to Lucinda McDade and Mark Porter, for being there at all the stages of my research. I am deeply grateful to Douglas Daly, for his incredible support when I was just an undergrad interested in Burseraceae. Eighteen years later, I am even more interested, but now feel I made a difference with this project. Thanks for your trust in me all this years!

Field work was the best part of this study, and it would not have been possible without my dear colleagues Jacqueline Perez, Lucía Hechavarría, Maikel Cañizares, Pedro González and Pedro Herrera in Cuba, Teodoro Clase in the Dominican Republic, and Dr. George Proctor and Keron Campbell in Jamaica. Thanks to Paul Fine for making possible my third expedition to Cuba. Julieta Rosell in Mexico, with her generosity and encouragement made possible the addition of critical information on Mexican Bursera to this work. Reinaldo Aguilar in Costa Rica, Alvaro Idárraga and Pablo Stevenson in Colombia provided me essential material for this study. Additional field samples were provided by Sandra Namoff, Jason López, John Trager and Shawn Krosnick.

Acquisition of important DNA data was possible thanks to Andrea Weeks, the support at the lab of Shawn Krosnick, Erin Tripp and the talented abilities of Siti Isa. Special thanks to Alejandra Vasco, for their assistance with leaf clearings, photographs and paisa hospitality in NY. I am deeply

grateful to the herbaria COL, COAH, F, FTG, G, GOET, H, HAC, HAJB, HMC, HUH, IJ, JBSD, K, LL, MO, NY, RSA, S, UPRRP and US for loans and their hospitality.

Very special thanks to Linda Prince, who took me right to the molecular lab on my first semester; I will never forget it! I thank from the bottom of my heart Linda Worlow for her enthusiasm and help with the little ones, paperwork and another thousand little things. Gracias! 
I also wish to thank Ken Edmunson for entertaining Juana, Sofía and Simón with books, toys and funny conversations during those long days at the lab.

Thanks to my dear friend Gilberto Ocampo, for his constant advice and coaching (sí se pudo!). Thanks to all my classmates at Rancho Santa Ana Botanic Garden (Hari Chhetri, Sarah De Groot, Jinyan Guo, Naomi Fraga, Kristen Hasenstab, Daisie Huang, Diana Jolles, Carrie Kiel, Bob Lauri, Saeideh Mashayekhi, Sula Vanderplank, Andrew Wheeler and José Zuñiga) for their very interesting/amusing debates at our Journal Club and (pizza) meetings. I will never forget you and hope to encounter you again through the botanical world. To Stephen Dreher for his friendship from the very beginning.

Funding was generously provided by the Graduate Student Research Awards Program of Rancho Santa Ana Botanic Garden, the Cactus and Succulent Society of America, and the Graduate Student Council Travel Awards at Claremont Graduate University. 


\section{TABLE OF CONTENTS}

Chapter One: Molecular Phylogenetics of Bursera (Burseraceae) in the Greater Antilles and the

INTRODUCTION

Chapter Two: Leaf architecture and anatomy of Bursera subgen. Bursera

30

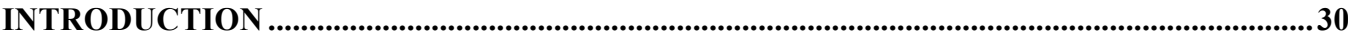

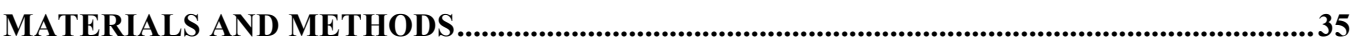

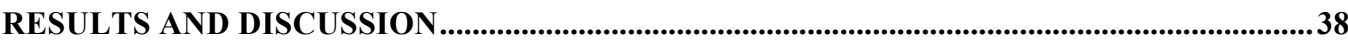

Chapter three: A taxonomic revision of Bursera subgen. Bursera ............................................................54

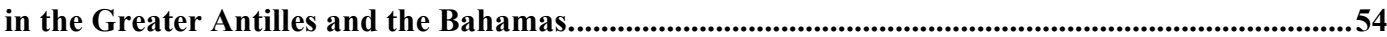

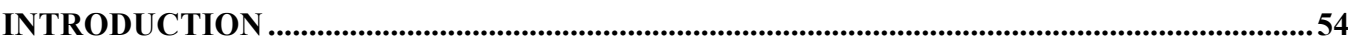

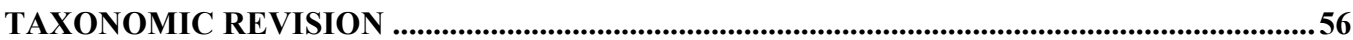

Key to the species of Bursera in the Greater Antilles and the Bahamas ........................................58

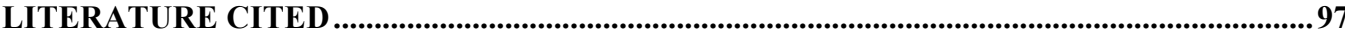

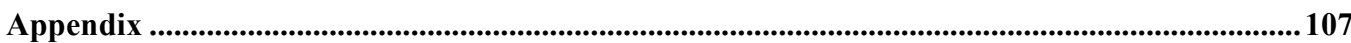




\section{LIST OF TABLES AND APPENDIX}

Table 1. Summary of results from phylogenetic analyses

Table 2. Results of the congruence (ILD) tests.

Table 3. Most Recent Common Ancestor (MRCA) for major clades)

Table 4. Species of Bursera subgen. Bursera sampled in the Greater Antilles and the Bahamas, distributions and voucher information.

Table 5. Characters and character states studied. 47

Table 6. Summary of some morphological and anatomical important leaf characters for Bursera subgen. Bursera in the Greater Antilles and the Bahamas. 48

Table 7. Characters that separate B. glauca from B. yaterensis 96

Appendix 1. Taxa sampled, secuence data and voucher information.. 107 


\section{LIST OF FIGURES}

Figure 1. Predicted topologies from biogeographical hypotheses on the colonization of the Greater Antilles.

Figure 2. Bayesian allcompat tree using a combined data matrix of five loci 27

Figure 3. Chronogram from a BEAST analysis of the combined nuclear and chloroplast sequence data.

Figure 4. Paleogeography of the Caribbean region. 29

Figure 5. Bayesian allcompat tree using a combined data matrix of five loci 49

Figure 6. Some characteristics of species of Bursera in the GAB. 50

Figure 7. Microsections of the middle lamina of the leaf or the terminal leaflet. 51

Figure 8. Leaf architecture of Bursera in the GAB. 52

Figure 9. Ancestral reconstructions for some characters of Bursera in the GAB. 53 


\section{Chapter One: Molecular Phylogenetics of Bursera (Burseraceae) in the Greater Antilles and the Bahamas}

\section{INTRODUCTION}

Bursera is a genus of shrubs and trees with all but one species distributed mostly in seasonally dry tropical forests (SDTF) and xeric shrublands from the southwestern United States to Central America, the Caribbean, and northwestern South America (Colombia, Venezuela, southwestern Ecuador, northwestern Peru and central and extreme northern Brazil). Remarkably, $B$. tonkinensis occurs in Vietnam. Bursera has ca. 106 species in all, ca. 80 of them endemic to Mexico where the genus is an important component of drier habitats in both diversity and abundance (Rzedowski and Guevara-Féfer, 1992); the Balsas River watershed alone is home to 48 species (Rzedowski et al., 2005). There has been much research on the taxonomy of the Mexican species of Bursera (Rzedowski and Kruse, 1979; Rzedowski et al., 2004, 2005; Rzedowski and Calderón, 2006) especially in the past decade, during which at least 13 species have been described (Rzedowski and Calderón, 2000a; 2000b; 2002; 2006; Rzedowski et al., 2007; Rzedowski and Rzedowski, 2008; de la Luz and Pérez-Navarro, 2010; Guevara-Féfer, 2010). Despite this attention, the circumscription of the genus is uncertain, and research is sorely needed on the numerous putative hybrids, reproductive biology, and on the taxonomy of several species complexes (Bullock, 1936; McVaugh and Rzedowski, 1965; Rzedowski and Ortiz, 1988; Weeks and Simpson, 2004).

Bursera belongs to the tribe Bursereae, along with Aucoumea and Commiphora. The two subgenera of Bursera are both monophyletic, but some molecular studies suggest that subgenus Elaphrium is sister to the Paleotropical genus Commiphora + B. subgen. Bursera (Weeks et al., 
2005; Weeks and Simpson, 2007), while other studies place Bursera as monophyletic and sister to Commiphora (Becerra, 2003; Becerra and Sarukhán, 2005; Rosell et al., 2010). The most comprehensive reconstruction based on DNA data, with nearly all Mexican Bursera sampled, found that whereas the combined dataset (nuclear PEPC, ETS, ITS, NIAi3, plastid psbA-trnH) supported monophyy of Bursera, analyses of the ETS and PEPC data separately instead support a sister relationship between Bursera subgen. Bursera and Commiphora (De-Nova et al., 2011).Only a few morphological characters separate Bursera and Commiphora as currently circumscribed. Gillett (1980) kept the genera separate on the basis of the former having branches only rarely spinose (vs. spines often present), the two series of stamens (sub)equal (vs. inner whorl usually shorter so that the two whorls do not overlap), distinct pseudaril shape, and the calyx shallow with lobes open (apert) in bud (vs. closed in bud), although only the apert calyx was consistently diagnostic. In practice, generic placement is often determined based on the place of collection (Bursera is New World, except Vietnamese B. tonkinensis; Commiphora is almost completely Old World, except South American C. leptophloeos and five Antillean species). Chromosome numbers have been reported for very few species, but so far they are consistently different (Bursera $2 n=24$, Commiphora $2 n=26$ ).

After Mexico, the region of second highest diversity and endemism for Bursera is the Greater Antilles and the Bahamas archipelago (hereafter abbreviated GAB), where ca. 16 species occur, 14 of them endemic to the region; all are part of $B$. subgen. Bursera, except widespread $B$. graveolens, which is part of $B$. subgen. Elaphrium. In the Greater Antilles, ca. $72 \%$ of angiosperm species are endemic (Santiago-Valentin and Francisco-Ortega, 2008), and many species are restricted to a single island or even to a particular habitat on one island. Habitat specialization likely played a role in speciation on the Caribbean islands, and in fact many species are narrow endemics associated with edaphic conditions (Borhidi, 1997). A clear example is B. shaferi, known only from the mogotes, or dogtooth limestone hills, that mostly occur along shorelines in Pinar del Rio 
Province in western Cuba.

Moncada-Ferrera (1989) transferred three species of Bursera to Commiphora-two Cuban endemics, B. angustata and B. glauca, and B. inaguensis of Cuba and the Bahamas - based on new diagnostic characters such as leaf and calyx morphology but especially pollen. Later, Borhidi (1992), based on Moncada-Ferrera (1989), proposed the transfer to Commiphora of two Dominican Republic endemics (B. ovata and B. spinescens) but without providing further morphological evidence. One of these, C. spinescens, appears in Weeks' (2005) phylogeny as part of the Bursera subgen. Bursera clade, with that clade sister to Old World Commiphora.

In this paper, I will refer to the relevant region of the Caribbean as the Greater Antilles and the Bahamas instead of the West Indies because there are no endemic species of Bursera in the Lesser Antilles. Recent research on the phylogeny of Burseraceae (Weeks et al., 2005) and the $B$. simaruba complex (Rosell et al., 2010) has shown that six GAB endemics form a clade nested within a monophyletic subgenus Bursera, but the position of that clade is not resolved. Both the $B$. simaruba complex and the GAB species of Bursera that have been included in phylogenetic studies to date belong to subgenus Bursera. The remaining eight species of GAB Bursera have yet to be placed phylogenetically. Further, as presented by Weeks and Simpson (2004), there is some molecular evidence of hybridization between some endemic species and B. simaruba in the Dominican Republic, but it is not known whether hybridization is a common mechanism in the GAB.

No morphological or molecular phylogenetic studies have focused on GAB endemics, the relationships among them — except the study mentioned above, or their relationships with the species in Central and/or South America, nor has there been any comprehensive taxonomic study of the GAB species. Little is known about their morphology and anatomy, much less about their reproductive biology. The present study includes all the endemic species of Bursera subgen. 
Bursera distributed in Cuba, Jamaica, Hispaniola and the Bahamas. Given their close relationship with GAB Bursera (Rosell et al., 2010), all members of the B. simaruba complex are also included. Additionally, to ensure adequately broad sampling, three additional intriguing species from the mainland are also part of this study: B. standleyana, from cloud forests in Costa Rica and the only hemi-epiphyte in Burseraceae, $B$. inversa, a canopy tree from the inundated tropical rainforest of Colombia, and a new species from dry tropical forests in Central Brazil, B. pereirae, all classified in the subgenus Bursera. Additionally, I include the only putative species of Bursera in the Paleotropics, the poorly known B. tonkinensis from Vietnam. The position of B. standleyana has been unclear (Rosell et al., 2010), B. tonkinensis appears sister to Commiphora (Weeks and Simpson, 2007), and sequence data for $B$. invers $a$ and $B$. pereirae are presented here for the first time. Given the morphological similarity and confusion about generic delimitations, as described above, taxa from African Commiphora were included, as well as members of the other two tribes of Burseraceae, Canarieae and Protieae as outgroups.

Several hypotheses have been proposed to explain the paleohistory of the Caribbean basin and thus the different scenarios under which lineages of organisms may have arrived and radiated. There have been increases in paleontological and stratigraphic information, as well as the use of dated phylogenies, to independently test these hypothesis, and in some instances incongruence has been found among biological, paleontological and paleogeographic results. Recent studies have tested biogeographic hypotheses against phylogenies of plants [e.g., Melastomataceae (BécquerGranados et al., 2008); Arecaceae (Roncal et al., 2008); Euphorbiaceae (van Ee et al., 2008)]; vertebrates [e.g., cichlid fishes, (Chakrabarty, 2006) and frogs (Poinar and Cannatella, 1987); and arthropods [e.g., spiders (Crews and Gillespie, 2010) and butterflies (Hall et al., 2004)]. Caribbean phytogeography must be regarded as unresolved, however, a critical review by Francisco-Ortega (2007) of 63 published phylogenies of endemic Caribbean genera concluded that most lack wellsupported clades, data from more than one molecular locus, and adequate sampling of putative 
relatives. As clearly stated by Iturralde-Vinent (2006), “The very existence of conflicting biological and geological interpretations demonstrates that the present level of scientific information for the Caribbean is still inadequate, but also suggests that a multidisciplinary approach is needed to resolve these problems."

All contemporary biogeographic hypotheses assume the mobilist model, which focuses on plate tectonics (Pindell and Barrett, 1990; Ricklefs and Bermingham, 2008), and there is general agreement on the origin of the Caribbean plate in the Pacific Ocean ca. $170 \mathrm{Myr}$ as a landmass that formed a Cretaceous Island Arc (Briggs, 1984). This Cretaceous Island Arc moved eastward, passing between the North and South American plates, and then broke apart due to uplift events in the Late Cretaceous. What remained of the plate, called the Paleogene Arc, drifted eastward and was probably connected to the southern part of the North American plate until 49 Myr (Pitman et al., 1993). In the Early Eocene, the Cayman Trough began to form, separating the North America Plate and the Paleogene Arc, which continued drifting east. It was probably only after the Middle Eocene, ca. $40 \mathrm{Myr}$, that land masses emerged that have remained to the present. Stretching of the Paleogene Arc and fluctuating sea levels broke land connections and created deep channels between the islands of the contemporary Greater Antilles (Iturralde-Vinent and MacPhee, 1999; IturraldeVinent, 2006). It is estimated that eastern Cuba and northern Hispaniola separated when the Oriente Fault formed in Early Miocene, ca. 20 Myr (Pindell and Barrett, 1990) and that western Cuba and central Cuba were separate landmasses until the Middle Miocene, ca. 15 Myr, when the HavanaMatanzas Channel disappeared (Iturralde-Vinent and MacPhee, 1999). Jamaica, southern Hispaniola and the Bahamas have different histories from that of Cuba, northern Hispaniola and Puerto Rico. Jamaica is a fragment of the Chortis Block/Nicaraguan Rise (part of northern Central America that drifted to the east), and marine formations suggest that it was largely submerged from mid-Tertiary to ca. 12 Myr (Ricklefs and Bermingham, 2008). Southern Hispaniola, another independent plate, adjoined northern Hispaniola during the Middle Miocene, 5-9 Myr and, as 
noted, by that time northern Hispaniola had already separated from eastern Cuba ca. $20 \mathrm{Myr}$ (Pindell, 1994). The Bahamas Platform is an ancient and stable geological feature, independent in origin from the Caribbean plates; its banks were exposed during Pleistocene, ca. 2 Myr.

Three main non-exclusive hypotheses have been proposed to explain the arrival of the contemporary biota in the Caribbean from adjacent regions, and there are several other hypotheses about the assemblage and movements of the plates of the Cretaceous Island Arc:

1. The first hypothesis proposes short-distance migration and posterior drift vicariance after a period of close proximity of the Chortis block (part of what is now western Jamaica) with the Paleogene Arc in the early Cenozoic, ca. 49 Myr, allowing several lineages to possibly reach the Paleogene Arc which then drifted, carrying biota from the North America plate (Pindell and Barrett, 1990; Pitman et al., 1993). The strongest evidence for this hypothesis is the discovery of fossils from a rhinoceratoid perissodactyl, and freshwater vertebrates from Early Eocene in what is today western Jamaica (Domning et al., 1997). However, this hypothesis is controversial because there is evidence of marine deposits on top of the fossil site. These fossils may be an example of the "Viking Funeral ship" scenario of McKenna (1973) as described by Iturralde-Vinent (2006), where fossils are deposited, later transported away and, when discovered, mistakenly interpreted to have existed when the land mass was in its current location. However, the modern presence of freshwater cichlids in Cuba and Hispaniola whose sister taxa are in Central America (Chakrabarty, 2006) suggests that at least a fragment of the Paleogene Arc remained above water and probably was in close proximity to the Chortis block.

2. This hypothesis proposes a more recent event, ca. 30-35 Myr, when a bridge - the now submerged Aves Ridge — may have emerged between South America 
and the emergent islands of the Greater Antilles (Iturralde-Vinent, 2006). This bridge, the Greater Antilles Aves Ridge or GAARlandia, would have made possible the migration of organisms from South America to the Greater Antilles. Evidence for this hypothesis is the presence on one or more of the Greater Antilles islands of South American groups, such as lineages of capromyid rodents, pitheciine primates and megalonchyd sloths (MacPhee and Iturralde-Vinent, 1995).

3. Finally, the dispersalist theory proposes long-distance migrations from centers of origin on the mainland. This has been a mechanism commonly invoked to explain colonization of remote islands of volcanic origin, and it could occur any time emergent land is available for colonization. However, long-distance dispersal cannot easily be ascribed to all organisms, as it depends on their vagility or dispersal abilities (Thorne, 1996).

Each of these three scenarios yields different predictions about the evolutionary history of taxa now present in the GAB. These predictions include the geographic location of the Most Recent Common Ancestor, MCRA (and therefore the direction of radiations) and the ages of divergence for the nodes in the phylogenies, representing the point in time and the place where the splits occurred between the populations that later evolved in the Greater Antilles and the Bahamas. These predictions, in the form of expected tree topologies and sister clade relationships, are depicted in Fig. 1. Comparison with a molecular phylogeny that uses fossils to calibrate nodes can provide an independent test of these biogeographic hypotheses, each of which summarize the opportunities for colonization available at a given time in a given part of the region and may apply to a given lineage.

This paper presents a phylogenetic reconstruction using DNA sequence data from five genetic loci to (1) test whether the GAB endemic species of Bursera are monophyletic and therefore radiated from a single common ancestor; (2) examine relationships among GAB species; (3) 
determine the phylogenetic position of the GAB species of Bursera that were transferred in the past to Commiphora by Moncada (1989) and Borhidi (1997); (4) determine the placement of South American B. inversa, B. standleyana and B. pereirae; (4) independently test the branching pattern of the phylogeny against the main hypotheses about the paleohistory of the Caribbean region, in particular for the Greater Antilles and the Bahamas; and (5) compare the dates of the estimated divergence times against the geologic record for the Caribbean region, in particular for the Greater Antilles and the Bahamas. An additional goal is to seek better resolution of the phylogenetic status and relationships of Bursera, because results of recent studies have been contradictory, as explained above. Including GAB and South American taxa, as done here, should help to resolve those relationships since previous studies have focused mainly on Mexican Bursera.

\section{MATERIALS AND METHODS}

Plant Samples—-Leaf samples were taken from 94 field collections and preserved in silica gel over the course of expeditions to Hispaniola, Cuba and Jamaica; these included several collections of the widespread species $B$. simaruba and all but one of the endemic species from the Greater Antilles, B. frenningae, which was obtained from the living collection at Fairchild Tropical Botanical Garden. Specimens exhibiting intermediate morphology between known species were also collected in native populations (some species are commonly used as living fences; these were avoided). Additional plant samples were obtained with permission from herbarium collections at COL, MEXU and NY. Samples of key outgroup species were collected by collaborators in Brazil, Colombia, Costa Rica, Mexico and Vietnam. A complete account of taxa sampled and voucher information is provided in Appendix 1. 
Taxon Sampling Strategy—Since some of the goals included the placement of GAB Bursera in the context of the genus as a whole and to nail down relationships both among island and between these and mainland taxa, a broad sampling strategy was used, aiming to include all potential close relatives of the GAB species in Central and South America. In total 66 taxa were used, 62 as ingroup and 4 as outgroup, The ingroup corresponded to all native species of Bursera and Commiphora on the Bahamas, Cuba, Jamaica and Hispaniola, including samples from populations in the Dominican Republic that have been reported as hybrids by Weeks and Simpson (2004). Given their close relationship to GAB Bursera (Weeks et al., 2005; Rosell et al., 2010), all members of the B. simaruba complex were also included (some as GenBank sequence data). Additionally, sequence data from Colombian B. inversa, Costa Rican B. standleyana and Brazilian B. pereirae are presented here. Given the lack of clear morphological distinctions between Paleotropical Commiphora and Bursera, nine species of the former were included. Members of the other two tribes of Burseraceae, Canarieae and Protieae were included as outgroups.

DNA Isolation and Sequencing-Approximately $20 \mathrm{mg}$ of dried leaf material were used for DNA extractions using DNeasy plant DNA Extraction Kit (Qiagen Inc., Valencia, California, USA) or the 2X CTAB Method (Doyle and Doyle, 1987). DNA product obtained with either method was quantified and concentration adjusted to ca.10ng/ $\mu 1$. Extractions from herbarium specimens yielded significantly less DNA than silica gel-dried specimens. I sequenced five markers: one low-copy nuclear locus (fourth intron of the phosphoenolpyruvate carboxylase gene, PEPC), one multiplecopy nuclear locus (external transcriber spacer region, ETS), two intergenic chloroplast spacers (psbA-trnH, rps16-trnK) and the intron sequence of the ribosomal protein gene rps16. These loci were chosen based on previous studies in Burseraceae (i.e., Weeks, 2004). Polymerase chain reactions (PCR) were performed using the following mix for each $25 \mu 1$ reaction: $2.5 \mu 1$ of Qiagen 10X PCR buffer, $1.25 \mu 1$ of dNTPs, $1.25 \mu 1$ of forward and reverse primers at $10 \mu \mathrm{M}$ each, $0.6 \mu 1$ of 
Bovine Serum Albumin (BSA), 10-100ng template DNA and $18 \mu$ l of distilled water. ETS was amplified using the primers Bur1-ETS1F (Weeks and Simpson, 2004) and 18S (Baldwin and Markos, 1998), with an annealing temperature of $56{ }^{\circ} \mathrm{C}$. PEPC was amplified using the primers PPCX4F and PPCX5R and temperature cycling protocol of Olson (2002). As reported by Weeks (2004), two sizes of PCR products were obtained and therefore each sample was cloned and ten transformed colonies were sequenced using the Strataclone PCR Cloning Kit (Stratagene, La Jolla, California, USA). The longer copy was alignable with the rest of the data matrix [from published GenBank sequence data of Weeks, 2005 and Rosell, 2010] and used for the study. I used the primers psbAF and trnHR and protocols from Sang et al. (1997) to amplify the $p s b A$-trnH intergenic region. The rps 16 intron was amplified with the protocol and primers rpsF and rpsR2 of Oxelman and Lidén (1997). Finally, PCR products for the rps16-trnK intergenic region were obtained using the primers rps16x2F2 and trnK (UUU), and the protocol of Shaw et al. (2007). PCR products were visualized on a $1.5 \%$ agarose gel, and positive bands were purified with halfreactions of ExoSAP-IT (USB, Santa Clara, California, USA). Cycle sequencing reactions were carried out with half-reactions of ABI Prism Big Dye Terminator solution (Applied Biosystems, Foster City, California, USA), and the same primer pairs from the PCR reactions were used at $1 \mathrm{~nm}$ concentration. Cycle sequencing products were cleaned using Sephadex G-50 medium and fine columns (GE Healthcare, Anaheim, California, USA) and run on an ABI Prism automated sequencer 3130xl (Applied Biosystems, Foster City, California, USA).

Sequence Editing and Alignment—DNA sequences from all loci were contiged and edited in Geneious 5.0.3 (Drummond et al., 2009) and aligned within the MUSCLE (Edgar, 2004) plug-in and adjusted by eye.

Phylogenetic Analysis —Data matrices were constructed with original sequence data for all the GAB species, some members of the B. simaruba complex, B. inversa, B. standleyana, $B$. 
pereirae and B. tonkinensis. Sequence data for Paleotropical Commiphora, C. leptophloeos, most of the B. simaruba complex and Canarieae and Protieae outgroup taxa were downloaded from GenBank (see details in Appendix 1). To test congruence among data sets, Incongruence Length Difference (ILD) tests (Farris et al., 1995) were performed in PAUP version 4 b10 (Swofford, 2002), with 10 random addition sequences and 1000 replicates. Preliminary analyses of the data were undertaken using maximum parsimony, maximum likelihood (ML) and Bayesian inference. Support values and tree topologies between the last two methods were very similar. Therefore, ML analyses are not reported here.

MAXIMUM PARSIMONY — Maximum Parsimony (MP) analyses for each individual locus and combined data sets were conducted in PAUP (Swofford, 2002) using a batch file that performed an heuristic search that saved all trees found in each of 1000 random addition replicates, tree bisection reconnection branch swapping (TBR) and multrees were in effect. Resultant trees were then filtered to choose the best trees which were saved to a different file. Gaps were treated as missing characters, and only informative characters were included, analyzed as unordered and with equal weight. Bootstrap support was obtained as suggested by Muller (2005), that is, a heuristic search with stepwise random addition, TBR and 10,000 replicates and MulTrees option disabled.

BAYESIAN INFERENCE-Best-fit models of nucleotide substitution were selected for each genetic marker and combined datasets using the Aikaike information criterion, as implemented in MrModeltest 3.7 (Posada and Crandall, 1998). The models of evolution used for the different analyses are presented in Table 1. Bayesian inference (BI) was implemented in MrBayes 3.1.1. (Ronquist and Huelsenbeck, 2003). For each dataset, the analysis consisted of four Monte Carlo Markov chains (MCMC), ten million generations with sampling every 1,000 generations, and a random tree as a starting point. The combined datasets were partitioned to assign the best-fit models of nucleotide evolution to each genetic marker. Majority rule trees were created after discarding a 
burnin of $30 \%$.

HYPOTHESIS TESTING—The likelihood-based Shimodaira-Hasegawa (SH) test (Shimodaira \& Hasegawa, 1999) was applied with two different topology constraints. One topology constraining Bursera as monophyletic and a second one for all GAB Bursera monophyletic. Differences in optimal tree scores were analyzed using PAUP (Swofford, 2002).

Estimation of divergence time - I estimated divergence times with Bayesian Evolutionary Analysis Trees (BEAST) 1.5.1 package (Drummond and Rambaut, 2006). BEAUti was used to prepare the XML file with the combined data matrix, manually assigning the best-fit model for each genetic marker (see Table 1). Minimum ages were assigned to the following three nodes according to a previous study by Weeks (2005): (1) the lineage that gave rise to Bursera and Commiphora (50 Myr), using a pyrene of Protocommiphora europea Reid and Chander, from the London Clay of southern England; (2) the lineage leading to B. subgenus Elaphrium (50 Myr), using an impression fossil of B. inaequalateralis (Lesquereux) MacGinitie, found in the Eocene Green River Flora of Colorado and Utah; and (3) the lineage leading to B. subgen. Bursera (35 Myr), using leaf impressions of B. serrulata MacGinitie from the Florrisant Beds of Colorado. I used a relaxed clock (Drummond et al., 2006), a randomly generated starting tree, and normal prior distribution for the most recent common ancestor (MRCA). The MCMC chains were set to run for 10,000,000

generations with a sampling frequency of 1,000. After running BEAST, the log file was imported in TRACER to assess whether the posterior distribution was similar to the priors specified. The bestsupported tree was then generated in TreeAnnotator and visualized on FigTree v.1.3.1 (Rambaut, 2006-2009). The geochronology in this paper corresponds to that of Gradstein et al. (2004). Ancestral distributions were reconstructed and traced in Mesquite version 2.74 (Maddison and Maddison, 2009), under the maximum parsimony criterion. 


\section{RESULTS}

Sequences-All sequence data were unambiguous to align. Total alignment lengths, including indels, for individual matrices were: 395 (ETS), 582 (PEPC), 784 (psbA-trnH), 887 (rps16 intron) and 899 (rps16-trnK) for a total of 3,547 characters, of which 420 were parsimony informative. Details about sequence data and analyses are presented in Table 1.

Phylogenetic analyses - Preliminary analysis with data sets including all samples

(not shown here), allowed the confirmation of the identity of some taxa with respect to previously published data (i.e., coalescence of sequence data of taxa hypothesized as hybrids with with samples from my field expeditions) as well as the detection of some misidentifications that are discussed below.

The combination of the nuclear and chloroplast genetic markers, and the rps 16 intron with PEPC and rps 16-trnK passed the combinability test $(\mathrm{P}=0.10)$, although most individual datasets were incongruent when combined to each other (Table 2), the phylogenetic reconstructions with MP and BI analyses of individual and combined datasets recovered the same major clades, albeit with some differences in topology. Fig. 2 shows the majority rule consensus of the posterior distribution of trees from the Bayesian analysis for the combined five loci, with their BI Posterior Probability (BPP) and MP bootstrap percentage (MP BP) support values.

In all analyses, all sampled taxa currently assigned to Commiphora (including the GAB species), do not form a clade; however, all sampled paleotropical Commiphora plus South American C. leptophloeos do form a clade that is sister to ((B. tonkinensis (B. inversa + B. pereirae) (B. subgen. Bursera $+B$. subgen. Elaphrium)) or is part of a polytomy that includes $B$. tonkinensis, B. inversa + B. pereirae, B. subgen. Elaphrium and B. subgen. Bursera (MP tree, not shown). All GAB plants transferred to Commiphora by earlier authors belong to Bursera subgen. 
Bursera.

The monophyly of Bursera requires additional testing (monophyletic under BI but not under MP). The reconstructed phylogenies strongly support (i.e., BPP >0.95 and BP >70): (1) monophyly of both subgenera of Bursera in all analyses; (2) within subgenus Bursera, the clade representing species of the B. simaruba complex is sister to three GAB species (B. nashii, B. ovata, B. angustata), with these together sister to a clade that includes the other thirteen GAB species (i.e., species of Bursera present in the GAB are not monophyletic; the two clades will subsequently be referred to as GAB-3 and GAB-13); (3) the Jamaican species form a clade, sister to (B. spinescens + B. brunea + B. gracilipes); (4) multiple accessions of ten species are monophyletic (i.e., do coalesce) whereas three are polyphyletic: B. angustata, B. glauca, B. inaguensis; (4) B. inversa and B. pereirae are sister taxa, but the position of this clade is ambiguous. These two taxa belong to subgenus Bursera and is its most basal taxon in the plastid combined analysis; (5) B. tonkinensis has only ETS sequence data and appears in that phylogeny as sister to Commiphora but appears in the combined dataset as the basalmost taxon within Bursera; (6) in all analyses, the Costa Rican $B$. standleyana is nested within GAB-13. These results are discussed further below.

Inferred divergence times — The topology of the chronogram obtained using BEAST (Fig. 3) is very similar to that of the Bayesian allcompat tree (Fig. 2). Mean values for the age of the MRCA and the values for the $95 \%$ highest posterior density interval (HPD) for the nodes of interest are shown in Table 3. According to these results, the mean age of clade GAB-13 is 23.46 Myr (13.0334.61; node F) and a separate colonization of what is now Cuba and Hispaniola occurred later, approximately $14 \mathrm{Myr}$ (4.76-27.04; node D), both events corresponding to Late Oligocene to Early Miocene. Fourteen more divergences occurred once the MRCA of GAB Bursera reached the islands, eight of them dated as Miocene (23-5 Myr), five in the Pliocene (5-2.4 Myr) and one during the Pleistocene (2.4-0.01 Myr). 


\section{DISCUSSION}

Position of GAB Commiphora - The lack of reliable morphological characters for separating B. subgen. Bursera from Commiphora has hindered taxonomic work, as members of the two genera are strikingly similar morphologically. Moncada-Ferrera (1989) used pollen morphology to justify transferring three species of Bursera to Commiphora (C. angustata, C. glauca and C. inaguensis); these have oblate-spheroidal pollen whereas B. simaruba, B. shaferi and B. graveolens have prolatespheroidal pollen. To date, the most complete pollen studies in Burseraceae show that these two shapes are common in the Bursera Alliance (i.e., Aucoumea, Bursera, Commiphora) and neither is diagnostic at the generic level (Daly et al., 2011). Additional morphological characters used by Moncada-Ferrera (1989) to separate these three species (leaflet shape, leaf venation, calyx shape) have been used traditionally in Burseraceae taxonomy at the species level and are not reliable as diagnostic characters to separate Bursera from Commiphora. All results presented here indicate that Paleotropical Commiphora and South American C. leptophloeos form a clade. Within that clade all members have fruits with seeds that have incompletely covered pseudaril whereas GAB Commiphora have fruits with seeds with complete pseudaril, a diagnostic character of Bursera subgen. Bursera. DNA sequence data evidence of this study confirms the placement of the GAB species currently treated in Commiphora within the genus Bursera. Additional anatomical and morphological evidence to better circumscribe these species is on chapter two.

Generic and infrageneric limits of Bursera-The present study is not conclusive with respect to the monophyly of Bursera. Resolution of relationships of the subgenera of Bursera with Commiphora will require broader sampling of both taxa and characters, and a thorough examination of the morphology of both groups. However, both subgenera are monophyletic. Three taxa that need further study are B. inversa, B. pereirae and B. tonkinensis: only partial DNA sequences were obtained and, perhaps as a result, their placements lack strong support. Their disjunct distributions 
(Colombia and Venezuela inundated forests, Brazilian cerrado, and humid karst topography in Vietnam, respectively) and apparently basally branching positions within Bursera, justify the acquisition of more molecular and morphological data about these taxa to fully establish their positions and roles in the evolution of the genus.

Polyphyletic taxa-The phylogenetic analysis showed that accessions of three species are polyphyletic: (1) Cuban endemic B. angustata has two terminal taxa. The sample placed with the GAB-3 within the B. simaruba complex, referred to herein as B. angustata A comes from an isolated population in west Cuba (Viñales Province), whereas the sample nested within GAB-13, referred to herein as B. angustata $\mathrm{B}$, was collected from a population in La Coca (Habana). The second accession may be of hybrid origin as individuals that are morphologically intermediate between $B$. angustata and B. simaruba have been found by the author in that population and on the hills of Agabama (Sancti Spiritus Province, Cuba) where these taxa are sympatric; (2) accessions of Cuban and Bahamian B. inaguensis are placed in two clades, one from a population from Inagua (Bahamas), is sister to $B$. frenningae and referred to herein as B. inaguensis $\mathrm{A}$; the second, from a population from Viñales (Cuba) is sister to $B$. angustata $\mathrm{B}$, and is referred to herein as $B$. inaguensis B; (3) B. glauca is also represented by two samples, one from the Pedernales Province (Dominican Republic), referred to herein as B. glauca, and the second from Guantánamo (Cuba). This last accession is from a plant that differs slightly morphologically from typical B. glauca and is referred to herein as $C$. aff. glauca. Direct comparison of available data from chloroplast and nuclear loci is not conclusive on the possibility of hybrid origin, but more sequence data and sample of populations may be necessary to study that. In this last case, hybridity, incomplete lineage sorting or insufficient molecular data could explain polyphyly. A careful examination of leaf morphology, anatomy and architecture of these samples is presented on chapter two, to establish if there are significant differences that would support recognition of multiple taxonomic entities. 
Weeks and Simpson (2004) proposed the hybrid origin of three endemic Hispaniolan species of Bursera as follows: B. brunea (B. nashii x B. simaruba), B. gracilipes (B. spinescens x B. simaruba), and B. ovata (B. simaruba $\times$ B. spinescens). I examined the voucher specimens used for that study, along with the type specimens of the taxa involved. Additionally, I examined the coalescence of sequence data (Weeks published GenBank data with my collections). As conclusion, the sequences published by Weeks and Simpson (2004) as B. brunea correspond to B. nashii, and sequences labeled as B. nashii correspond to that taxon (but B. nashii is a synonym of B. glauca, see chapter three). This confusion is vely likely due to thefact that all specimens of $B$. nashii deposited at JBSD are mistakenly labeled as B. brunea. Bursera gracilipes, in the other hand, is closely related to $B$. spinescens and its hybrid origin with $B$. simaruba is plausible. Finally, plants that Weeks and Simpson treated as B. ovata may represent a new species of hybrid origin, but additional material is needed for its publication.

A new species of Bursera- A series of collections from East Cuba deposited at the herbarium of the Instituto de Ecología y Sistemática de La Habana were found, annotated by the late Cuban botanist Johannes Bisse as a new species of Bursera. New collections and DNA samples confirmed this as a new species, B. gibarensis. This new species is known from a single locality in Holguin Province, on xeromorphic coastal dogtooth karst topography. It is distinct from other Bursera by its (1)3-foliolate leaves, the leaflets small $(2.5 \times 0.5 \mathrm{~cm})$, narrowly lanceolate, and with the midvein prominent on the abaxial surface. Bursera gibarensis belongs to GAB-13 and its relationships and biogeography are discussed below (node $\mathrm{N}$ ).

Divergence times and biogeographical implications-NODES A-E-All analyses show that all GAB Bursera and the B. simaruba complex are monophyletic (inclusive of Central Amerian $B$. standleyana which is nested within GAB-13) (Fig. 3, node A). The ancestral area reconstruction shows that this lineage comes from a Central American ancestor (Fig. 3, nodes 2 and 3). The 
BEAST analysis estimates an age of ca. 27.84 Myr for this clade's MRCA. This result agrees to the age estimate presented by Iturralde-Vinent (2006) for the presence of permanently emerged land in the Caribbean, i.e., only since the Middle Eocene (ca. 40 Myr). The Eocene-Oligocene transition (35-33 Myr) was the peak of an orogenic uplift of land in the Caribbean and thus dry land was at its maximum for colonization. The Eocene-Oligocene transition is also the time during which the Greater Antilles Aves Ridge is hypothesized to have emerged between the Greater Antilles and South America (GAARlandia, Fig. 4). At that time, Central and Eastern Cuba, northern Hispaniola and Puerto Rico were connected to each other and also to portions of the emergent Aves Ridge, providing periods of dry-land connection to South America (Iturralde-Vinent, 2006). However, the reconstructed tree indicates that all the GAB species of Bursera have a Central American ancestor, and no sister relationships are recovered with South America. Independent evidence for the presence of Bursera taxa at this time are fossils of Bursera in Middle Oligocene lignites from the San Sebastian formation of Puerto Rico (Graham, 2003); it was not possible to examine these for the present study and they were not used as calibration data.

Nodes D and E indicate that the GAB species of Bursera are paraphyletic, with two independent colonization events that gave rise to three and 14 species, respectively. According to the phylogenetic estimate and the ancestral reconstruction (node B, ca. $20 \mathrm{Myr}$ ), a common ancestor from Central America or Hispaniola gave rise to two lineages: one evolved into the B. simaruba complex that radiated within Central America, especially what is now Mexico (node C, ca. 13.79 Myr) and a second lineage evolved in what is now Hispaniola (node D, ca. 13.35 Myr). If the divergence of this last clade evolving in Hispaniola corresponds with the current distribution of its most basal species (B. trinitensis) in Pedernales Province in the Dominican Republic, it would agree with the time when S Hispaniola emerged, providing new land available for colonization (IturraldeVinent, 2006). Node E represents the sister relationship of B. glauca and B. angustata A. 
NODE F-According to the reconstruction of ancestral areas, the first lineage to arrive in the GAB could have originated in Central America or in situ, on one of the emerged islands (Cuba, Hispaniola or Jamaica) in Early Miocene (node F, ca. $22 \mathrm{Myr}$ ). The result is equivocal, but it can be speculated that if Jamaica was the place of origin, then it must be assumed that the island was available in Early Miocene, an unlikely event given the existing stratigraphic evidence. From this lineage's MRCA there was a divergence into a Cuban clade (node G, ca. 11.59 Myr) and a second MRCA (node N, ca. 17.89 Myr) that evolved independently in Hispaniola (node O, ca. 14.02 Myr) and Jamaica (node Q, ca. 9.8 Myr). The ages of these divergence times correspond with further isolation of land areas by the active tectonic subdivision of the northern and southern Caribbean plate boundaries. This isolation has been proposed to explain, for example, island to island vicariance of megalonychid sloths and pitheciine primates, although their origin is completely different as they are hypothesized to have arrived to the Caribbean through the GAARlandia land bridge from South America (Iturralde-Vinent and MacPhee, 1999; MacPhee and Iturralde-Vinent, 2000).

NODES G-M, CUBAN CLADE- The MRCA of the species contained in node G had its ancestral distribution in Cuba; both taxa of the earliest diverging clade, B. shaferi + B. cf. glauca (node K, ca. 9.49 Myr), are restricted endemic species from western and eastern Cuba, respectively. There is a clade of three species (node I, ca. 7.19 Myr) whose MRCA was located in E Cuba in late Miocene. The most basal species of this clade, B. gibarensis is a restricted coastal endemic from Holguin Province, in close proximity to the Bahamas. The presence of a derived pair of species on the Bahamas (but especially B. frenningae, known only from Exuma island) likely represents a dispersal event from Cuba (node J, 3.8 Myr), although the estimated date predates the hypothesized emergence of the Bahamas platform, ca. 2 Myr. The proximity of Cuba and the Bahamas archipelago explains their strong floristic affinities. Chiappy et al. (1988) found that NE Cuba and the Bahamas share $99 \%, 78 \%$ and $53 \%$ of families, genera and species, respectively. Finally, the 
Cuban clade also contains a dispersal event during the Pliocene (node L, ca. 6.6 Myr), from Cuba to Costa Rica, which resulted in the evolution of the endemic $B$. standleyana. This species is poorly known, but its habit (a hemi-epiphyte that becomes a canopy emergent in rainforest of ca. $3800 \mathrm{~mm}$ annual rainfall), might represent an adaptation to avoid high humidity (Williams and Cuatrecasas, 1959). Bursera standleyana is sister to B. angustata $B+B$. inaguensis $B$ (both from Cuba). These last two species are similar morphologically (compound leaves 5-9-foliate, inflorescences longer than petiole). As with B. angustata, B. inaguensis is polyphyletic in my results. A morphological and anatomical study is underway to clarify the identity of what is currently known as B. angustata and B. inaguensis (i.e., different taxonomic entities with morphological convergence or polyphyletic species).

Nodes $N-R$ - Sister to the Cuban clade is a lineage that evolved in Hispaniola and later in Jamaica. The Hispaniola clade (node $\mathrm{O}, 14.02 \mathrm{Myr}$ ) has $B$. spinescens as its basal most taxon that is estimated to have evolved from its MRCA ca. 14.02 Myr, around the time when N Hispaniola separated from E Cuba. Sister to B. spinescens are B. gracilipes and B. brunea. The Jamaican clade's estimated age reconstructed here (node Q, 9.8 Myr), independently supports the hypothesis that Jamaica was submerged until Late Miocene, ca. 10 Myr. This finding also supports the idea that Jamaica's modern biota arrived via dispersal (Graham, 2003; Ricklefs and Bermingham, 2008). As noted, in its origin Jamaica possesses a different paleohistory than the other islands. The presence of land mammal fossils during the early Eocene (Domning et al., 1997) and extensive geologic evidence (Iturralde-Vinent, 2006) support the idea of Jamaica as a fragment of mainland that drifted and then was submerged until its latest emergence in late Miocene. Relationships of Bursera within Jamaica, as elucidated from the phylogenetic reconstruction, show that $B$. hollickii and B. lunanii are sister (node R, ca. $4.09 \mathrm{Myr}$ ) and share a common ancestor with B. aromatica (node Q). It is interesting that $B$. hollickii and B. lunanii occur sympatrically on limestone hills near the coast, and those two species possess distinctive morphological characters (B. lunanii is the only 
Jamaican species with unifoliolate/simple leaves whereas those of $B$. hollickii are 3-7-foliolate). Bursera aromatica, however, is endemic to the mesic forest over limestone found in the Cockpit Country, a "hot spot" for endemism in the West Indies (Jestrow et al., 2008). To date morphological synapomorphies for this Jamaican clade have not been identified, although all species are monopodial, unlike most other GAB Bursera.

LATE MIOCENE-PLEISTOCENE RADIATION—Five recent sister relationships that date to 3.84.9 Myr indicate a contemporaneous radiation of species within Jamaica (B. lunanii and $B$. hollickii), the Bahamas (B. inaguensis A and B. frenningae), central Cuba (B. angustata B and B. inaguensis B), Hispaniola (B. gracilipes and B. brunea), and between Cuba and Hispaniola (B. angustata $\mathrm{A}$ and B. glauca). Probably a combination of abiotic and biotic conditions (temperature, wind patterns, bird migration tracks) favored the dispersal of seeds among the islands and within Central America. However, radiation within the islands resulted in the development of a series of endemic species with narrow distributions (annotated in Fig. 3). It has been suggested that species on islands, once evolved, "lose" their dispersal capabilities, perhaps as a trade-off for habitat specialization (Carlquist, 1966).

\section{CONCLUSIONS}

The monophyly of Bursera requires additional testing. As shown in previous studies, both subgenera and Commiphora are monophyletic. Five species previously transferred to Commiphora are confirmed with molecular evidence as Bursera. The species of Bursera in the Greater Antilles and Bahamas are paraphyletic and arrived in the region via two separate colonization events likely via dispersal from Central America. The present data corroborate previously published paleogeographic events within the Caribbean region, especially between Middle Miocene to Pleistocene, when Bursera underwent its larger radiation both within and among emergent lands. 
There was one dispersal event to the mainland, which yielded the hemi-epiphyte B. standleyana. The relatively recent sister pair $B$. inaguensis $\mathrm{B}+B$. frenningae corroborates the close floristic affinities of East Cuba with the Bahamas. A new endemic species of Bursera in Cuba was discovered and its relationships analyzed. This study provides a framework for more detailed morphological studies that are needed to resolve the apparently polyphyletic taxa $B$. angustata, $B$. inaguensis and B. glauca. The position and biogeographic implications of B. inversa and $B$. tonkinensis continue to be a mystery and more data is needed to understand the role of these basally diverging species in the evolution of the genus Bursera. 


\section{TABLES AND FIGURES}

Table 1. Summary of results from phylogenetic analyses. nac $=$ number of aligned characters; pic $=$ number of parsimony informative characters. $\mathrm{CI}=$ confidence index, $\mathrm{RI}=$ retention index, $\mathrm{RC}=$ rescaled retention index.

\begin{tabular}{cccrccccccc}
\hline Dataset & No. taxa & nac & pic & Tree length & $\begin{array}{c}\text { Missing } \\
\text { taxa }\end{array}$ & $\begin{array}{c}\text { Missing } \\
\text { data (\%) }\end{array}$ & CI & RI & RC & $\begin{array}{c}\text { Selected model for } \\
\text { Bayesian analysis }\end{array}$ \\
\hline ETS & 59 & 399 & 131 & 553 & 6 & 11 & 0.503 & 0.728 & 0.366 & GTR+G \\
PEPC & 42 & 582 & 99 & 318 & 12 & 6 & 0.780 & 0.866 & 0.673 & HKY+G \\
psbA-trnH & 43 & 799 & 116 & 269 & 14 & 35 & 0.825 & 0.917 & 0.757 & GTR+G \\
rps16 intron & 44 & 931 & 65 & 219 & 15 & 17 & 0.694 & 0.787 & 0.546 & GTR+G \\
rps 16-trnK & 33 & 900 & 53 & 126 & 22 & 57 & 0.791 & 0.894 & 0.707 & GTR+G \\
Combined & 59 & 3547 & 420 & 1663 & & & 0.488 & 0.746 & 0.487 & \\
& & & & & & & & & & \\
\hline
\end{tabular}

Table 2. Results of the congruence (ILD) tests.

\begin{tabular}{lcccccc}
\hline \multicolumn{1}{c}{ Datasets } & ETS & PEPC & psbA-trnH & rps 16 intron & rps 16-trnK & combined chloroplast \\
\hline ETS & -- & 0.01 & 0.01 & 0.01 & 0.01 & 0.01 \\
PEPC & & -- & 0.03 & $\mathbf{0 . 4 7}$ & 0.01 & 0.04 \\
psba-trnH & & & -- & 0.01 & 0.01 & -- \\
rps16 intron & & & -- & 0.11 & -- \\
rps16-trnK & & & & -- & -- \\
Combined nuclear & & & & & $\mathbf{0 . 1 0}$ \\
\hline
\end{tabular}


Table 3. Most Recent Common Ancestor (MRCA) for major clades (in millions of years) and support values of nodes from Bayesian posterior probability (BPP) and the bootstrap percentage support from the independent Maximum Parsimony analysis (MPBP). Node letters correspond with those in Fig. 3. and the text. GAB-3=clade of three GAB species; GAB-13= clade of thirteen GAB species. nr=relationship not recovered (part of a polytomy) .

\begin{tabular}{|c|c|c|c|c|c|c|c|}
\hline \multirow{2}{*}{\multicolumn{2}{|c|}{ Node Most recent common ancestor of }} & \multirow[b]{2}{*}{ Mean } & \multicolumn{4}{|c|}{$95 \%$ Highest posterior density } & \multirow[b]{2}{*}{ MPBP } \\
\hline & & & Lower & Upper & Geologic time & $\mathrm{BI}$ & \\
\hline A & B. simaruba complex $+\mathrm{GAB}$ Bursera & 27.84 & 16.46 & 38.07 & Lower Eocene & 1 & 97 \\
\hline B & B. simaruba complex $+\mathrm{GAB}-3$ & 20.07 & 10.24 & 32.86 & Early Miocene & 1 & 79 \\
\hline $\mathrm{C}$ & B. simaruba complex & 13.79 & 5.65 & 30.02 & Mid Miocene & 0.89 & 61 \\
\hline $\mathrm{D}$ & GAB-3 & 13.35 & 4.76 & 27.04 & Mid Miocene & 1 & 72 \\
\hline $\mathrm{E}$ & B. glauca + C. angustata $\mathrm{A}$ & 5.63 & 0.52 & 15.83 & Pliocene & 1 & 96 \\
\hline $\mathrm{F}$ & GAB-14 & 22.91 & 13.03 & 34.61 & Early Miocene & 1 & 69 \\
\hline G & Cuban & 11.59 & 6.15 & 24.18 & Late Miocene & 1 & 98 \\
\hline $\mathrm{H}$ & Cuban clade- 5 & 10.05 & 2.06 & 21.14 & Late Miocene & 1 & 92 \\
\hline I & B. gibarensis + Bahamas clade & 7.19 & 0.7 & 16.93 & Pleistocene & 0.92 & n.r. \\
\hline $\mathrm{J}$ & Bahamas clade & 3.8 & -- & - & Late Miocene & & \\
\hline $\mathrm{K}$ & B. shaferi + B.cf. glauca & 9.49 & 1.78 & 17.12 & Pliocene & 0.97 & 64 \\
\hline $\mathrm{L}$ & B. standleyana + Cuban clade- 2 & 6.6 & 1.85 & 21.19 & Late Miocene & & \\
\hline M & Cuban clade- 2 & 4.36 & 0.39 & 14.8 & Pliocene & 1 & 75 \\
\hline $\mathrm{N}$ & Hispaniola + Jamaica clade & 17.89 & ---- & ---- & Pliocene & & \\
\hline $\mathrm{O}$ & Hispaniola clade & 14.02 & 5.67 & 25.26 & Late Miocene & 1 & 98 \\
\hline$P$ & B. gracilipes $+B$. brunea & 4.65 & 2.87 & 20.28 & Late Miocene & 1 & 66 \\
\hline & Jamaica clade & 9.8 & & & & & \\
\hline $\mathrm{R}$ & B. hollickii + B. lunanii & 4.09 & .6 & 16.67 & Pliocene & 0.67 & n.r. \\
\hline
\end{tabular}



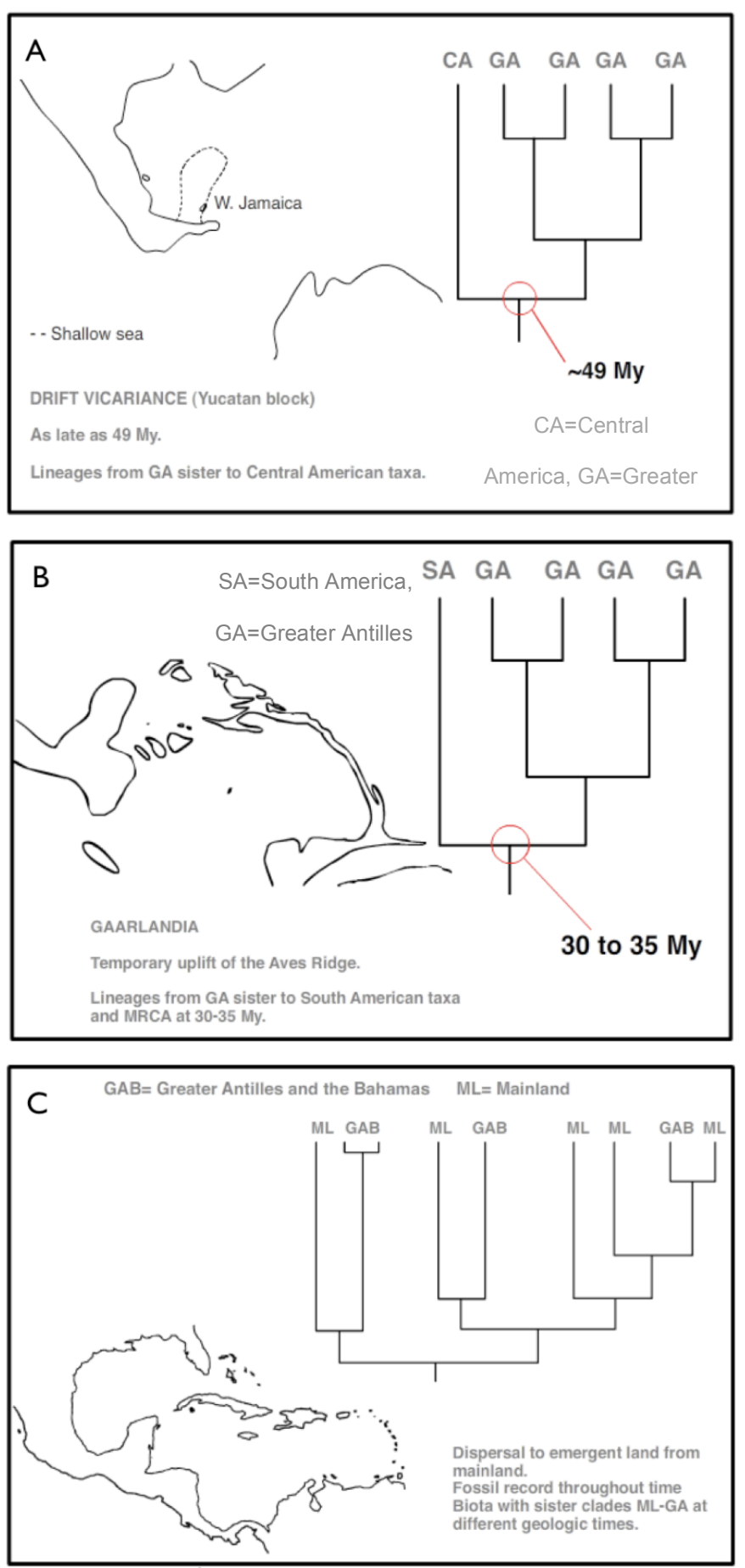

Figure 1. Predicted topologies from biogeographical hypotheses on the colonization of the Greater Antilles. The Bahamas are not considered in scenarios A and B because they belong to the $\mathrm{N}$ America platform and emerged permanently only in the Pleistocene (ca. 2 Myr). A. Drift vicariance of the Yucatan Block: if the Paleogene Arc was connected to the Yucatan Block with W Jamaica but probably also parts of what are today Cuba and Hispaniola subsequently drifting to their current positions, then reconstructed phylogenies would show sister clades represented by GA and Central America taxa, with divergence times as late as 49 Myr. Note that during this time, most of the Paleogene Arc was submerged. B. GAARlandia: if an emergent Aves Ridge facilitated migration between South America and the GA, reconstructed phylogenies would show sister clades of GA taxa derived from a South American ancestor around 30-35 Myr. C. Longdistance dispersal: assuming this as the mechanism of arrival to the GA, reconstructed phylogenies will lack a 
sister pattern with any particular mainland source and will present nodes of divergence throughout time rather than a concentration of nodes at a particular time. There is no particular plate arrangement prerequisite for dispersal, but shorter distances between an island and its source would favor this event. A, B and C adapted from Iturralde-Vinent 2006, with authorization from the autor. 


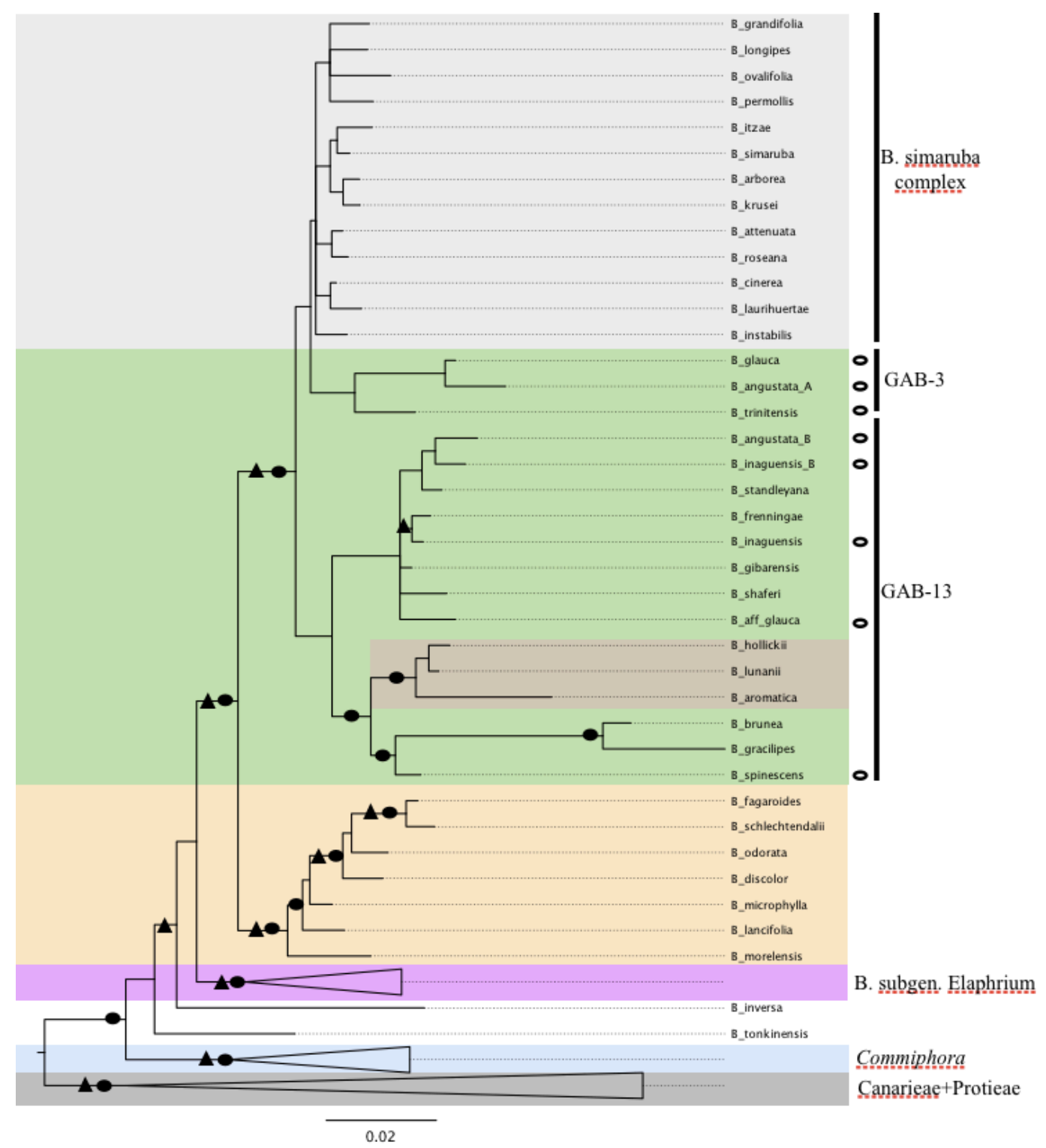

- $\mathrm{BPP}>0.95$

- MP BP $>70$ ○ GAB Commiphoro

Figure 2. Bayesian allcompat tree using a combined data matrix of five loci (ETS, PEPC, rps 16 intron, $r p s$ 16-trnK intergenic spacer and $p s b A$-trnH intergenic spacer). Colors represent the groups consistently recovered with independent loci. $\mathrm{BPP}=$ Bayesian posterior probability, $\mathrm{MP} \mathrm{BP}=$ Maxium parsimony bootstrap percentage. Open circle denotes species previously transferred to Commiphora. 


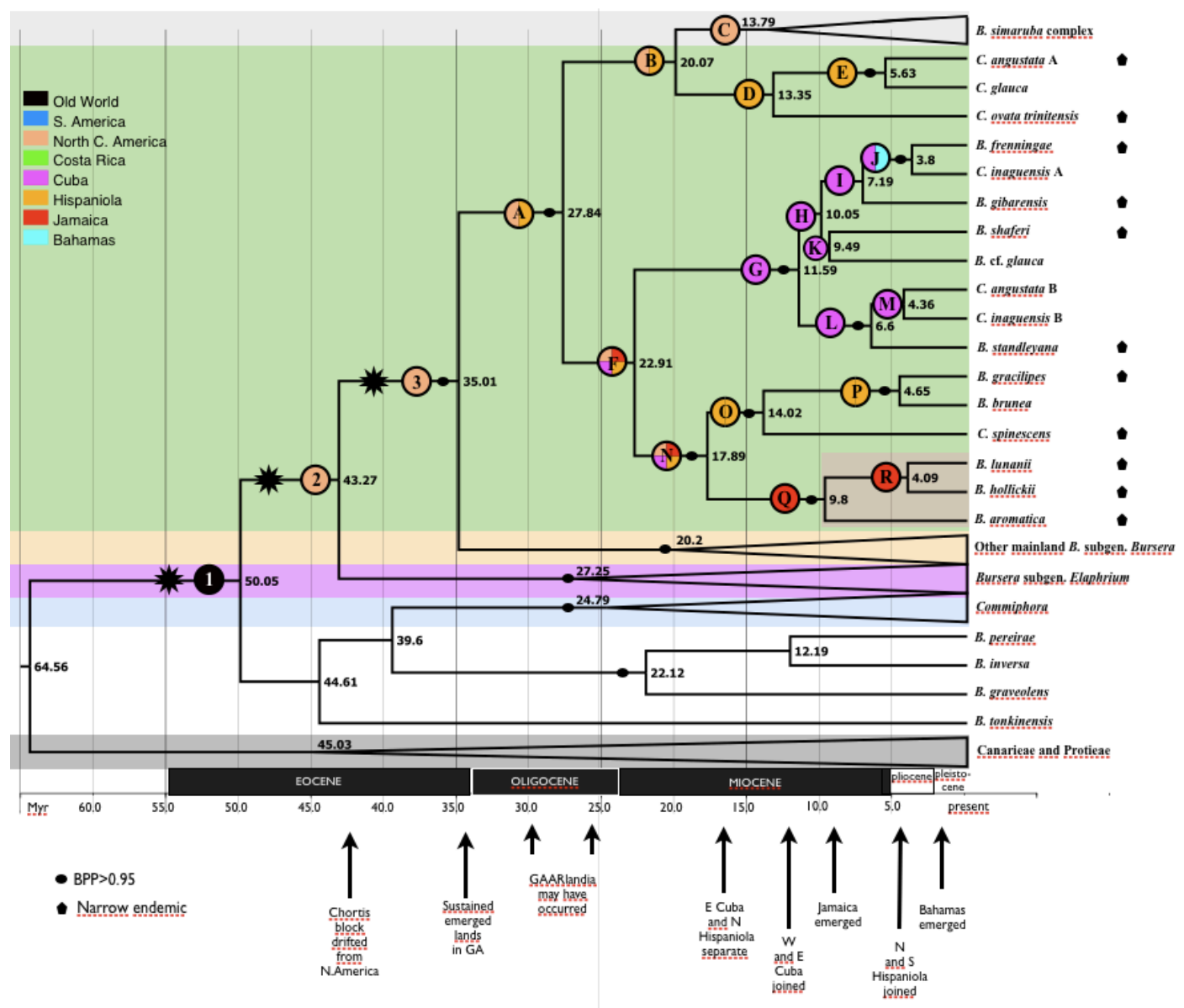

Figure 3. Chronogram from a BEAST analysis of the combined nuclear and chloroplast sequence data. Asterisks indicate fossil calibrations. Colored circles correspond to the ancestral area reconstruction and the letters and numbers, to the nodes discussed in the text. Main paleogeographical events and their estimated dates are shown from middle Eocene to Pliocene. 

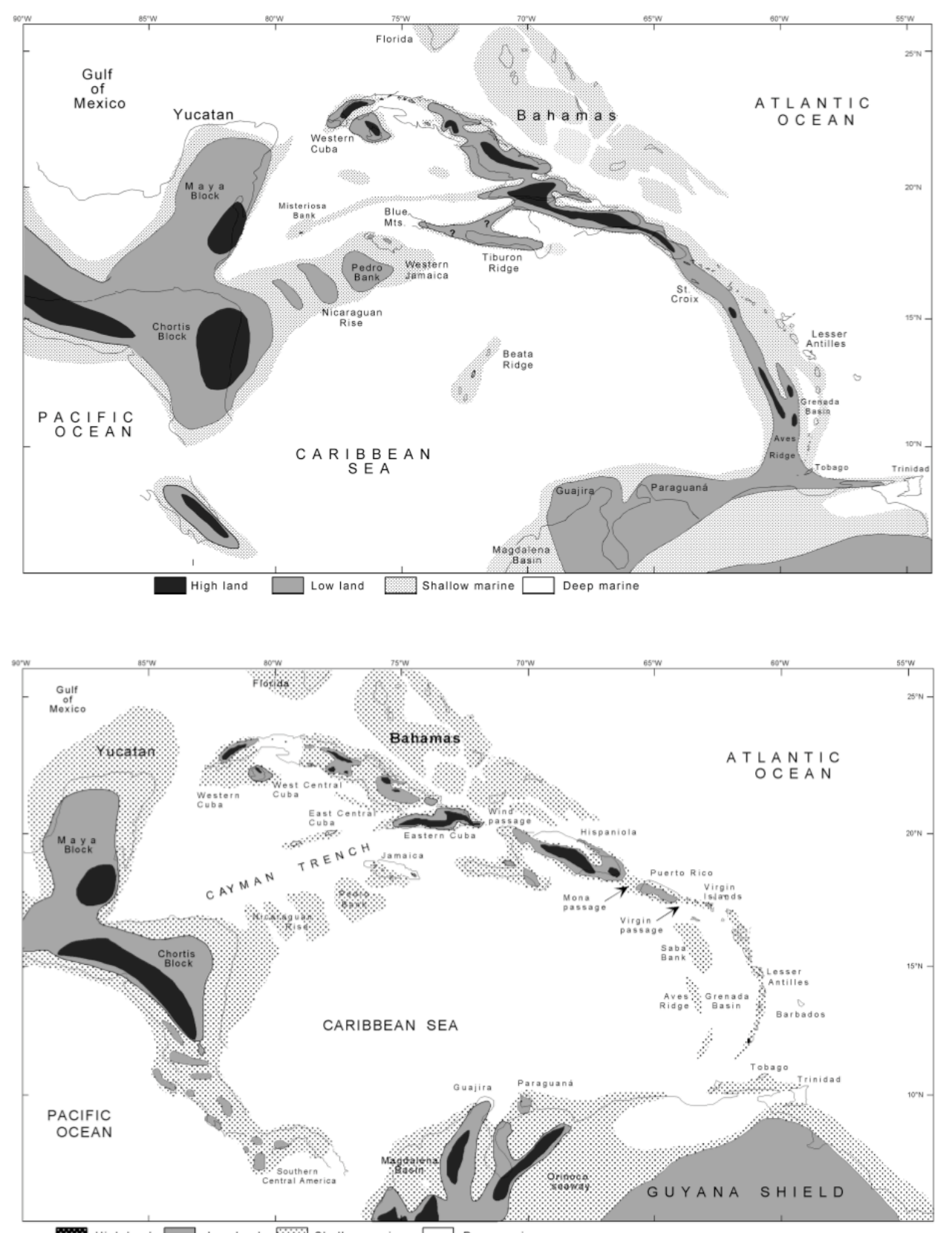

Figure 4. Paleogeography of the Caribbean region. A) Transition Eocene-Oligocene, ca. 35-33 Myr. GAARlandia hypothesis, during the period of maximum Cenozoic land exposure. B) Early Middle Miocene, ca. 16-14 Myr. Deep marine channels isolated W Cuba and shallow marine regions separated Central and East Cuba and North Hispaniola. Jamaica and S Hispaniola started to emerge as lowlands. Source IturraldeVinent 2006, reproduced with authorization from the author. 


\section{Chapter Two: Leaf architecture and anatomy of Bursera subgen. Bursera in the Greater Antilles and the Bahamas. Phylogenetic implications and taxonomy}

\section{INTRODUCTION}

Bursera (Burseraceae) is a Neotropical genus of approximately 106 species of shrubs and trees distributed mostly in seasonally dry tropical forests (SDTF) and xeric scrub from the southwestern United States to Central America, the Caribbean, and northwestern South America (Colombia, Venezuela, southwestern Ecuador, northwestern Peru and central and extreme northern Brazil). Historically, Bursera has two subgenera, subgen. Bursera and subgen. Elaphrium, sometimes referred to as sections Bursera and Bullockia, respectively. Approximately 80 species of Bursera are endemic to Mexico (Rzedowski and Guevara-Féfer, 1992); the Balsas River watershed alone is home to 48 species (Rzedowski et al., 2005). There has been much research on the taxonomy of the Mexican species of Bursera (e.g., Rzedowski and Kruse, 1979; Rzedowski et al., 2004, 2005; Rzedowski and Calderón, 2006), especially in the past decade, during which at least 13 species have been described (Rzedowski and Calderón, 2000a, b; 2002; 2006; Rzedowski et al., 2007; Rzedowski and Rzedowski, 2008; de la Luz and Pérez-Navarro, 2010; Guevara-Féfer, 2010). The second most diverse region for Bursera is the Greater Antilles and the Bahamas (GAB), with a total of 15 species (all belonging to subg. Bursera); 14 of these are endemic to the region, the last, $B$. simaruba, is the most widespread species of the genus. Most species in GAB are restricted to single islands: Jamaica (B. aromatica Proctor, B. hollickii (Britt.) Fawc. \& Rendle, B. lunanii (Spreng.) C.D. Adams \& Dandy ex Proctor), Cuba (B. angustata Wright ex Griseb, B. gibarensis M. C. Martínez, Daly, \& J. Pérez, B. shaferi Urb.), Bahamas (B. frenningae Correll), and Hispaniola (B. gracilipes Urb. \& Ekman, B. spinescens Urb. \& Ekman, B. trinitensis R.O.Williams ). Bursera brunea Urb. \& Ekman occurs in Hispaniola and Bahamas, B. inaguensis occurs in East Cuba and 
Inagua (Bahamas), and B. glauca is present in West Cuba and Hispaniola. The GAB species occur in tropical subdeciduous and deciduous forests on karst or serpentine soils.

With the exception of a wood anatomy study of two Bahamian species (Stevenson, 1979), there are no published studies of morphology or anatomy of these plants. Information about the endemic species is restricted to species descriptions or lists of local flora. Species from this region are often misidentified in herbaria and in the field, usually following upon the misidentification of another specimen(s). Despite the geographic proximity of the islands and the affinities of their floras, it is disconcerting that there has been so little exchange of herbarium specimens (even between Haiti and the Dominican Republic), which perpetuates the misidentifications.

In the paleotropics, the counterpart of the genus Bursera is Commiphora. Morphological and molecular data support a very close relationship between the two genera. The two subgenera of Bursera are monophyletic, but some molecular studies suggest that subg. Elaphrium is sister to the Commiphora + subg. Bursera (Weeks et al., 2005; Weeks and Simpson, 2007), whereas other studies support the monophyly of Bursera (Becerra, 2003; Rosell et al., 2010). De-Nova et al. (2010) employed DNA sequence data (nuclear PEPC, ETS, ITS, NIAi3, plastid $p s b A-t r n H$ ) from nearly all Mexican Bursera species. Analyses of the concatenated data showed Bursera to be monophyletic, but the separate analyses of ETS and PEPC still support a sister relationship between Bursera subgen. Bursera and Commiphora.

Recent molecular phylogenetic work by the present author using nuclear (ETS and PEPC) and plastid markers ( $p s b A$-trnH, rps 16 intron and $\operatorname{rps} 16-\operatorname{trnK}$ ), focused on the evolutionary relationships among species of Bursera from the GAB and their mainland relatives (Figure 1), represented by the monophyletic $B$. simaruba complex, found that (1) relationships between the two genera are still unclear; (2) two separate lineages of GAB Bursera (called GAB-3 and GAB-13 based on the number of terminal taxa) colonized the islands from Central America during the 
Miocene; (3) five Antillean species previously transferred to Commiphora (i.e., Moncada-Ferrera, 1989; Borhidi, 1997) in fact belong to Bursera. so that the only true species of Commiphora in the Neotropics is C. leptophloeos; and (4) three species appear to be non-monophyletic (B. angustata, B. inaguensis, B. glauca). Cuban endemic $B$. angustata has two terminal taxa. The sample placed with GAB-3 (i.e., within the B. simaruba complex) is referred to herein as B. angustata A and comes from an isolated population in west Cuba (Viñales Province). The sample nested within GAB-13, referred to herein as B. angustata $\mathrm{B}$, was collected from a population in La Coca (Habana). Accessions of Cuban and Bahamian B. inaguensis are placed in two clades. Bursera inaguensis A from a population from Inagua (Bahamas) is sister to B. frenningae. The second, from a population from Viñales (Cuba), is sister to B. angustata $\mathrm{B}$, and is referred to herein as $B$. inaguensis B. Samples of B. glauca from Pedernales Province (Dominican Republic), and from Guantánamo (Cuba) are not sister. The former is referred to as B. glauca; the latter is from a plant that differs slightly morphologically from typical B. glauca and is referred to herein as $C$. aff. glauca. Direct comparison of available data from chloroplast and nuclear loci was not conclusive regarding the possibility of hybrid origin of these three species. It is argued that hybridization, incomplete lineage sorting or insufficient variation of molecular data could explain the polyphyly exhibited by these species. As mentioned above, the present study seeks morphological and anatomical data from leaves to evaluate these phylogenetic results, including the non-monophyly of the species just mentioned.

There is a great deal of variability in the morphology of some Bursera species, including leaves (Daly, 1993; Rosell et al., 2010). The focus on leaves is also justified by the paucity of informative characters from reproductive organs in Bursera (Daly, 1993). Leaf characters are important for circumscribing species, but the evolution of this organ in the genus has not been elucidated. Rzedowski and Kruse (1979) recognized some "evolutionary tendencies," including a negative correlation between leaf surface area and rainfall in both subgenera; they considered 
compound leaves as the ancestral state and simple or unifoliolate leaves as derived.

A recent study targeted the $B$. simaruba complex (Rosell et al., 2010), in which "high levels of intraspecific morphological plasticity coexist with marked overlap between species." Detailed study of morphological variation in this species complex revealed that fruit and leaflet pubescence and maximum leaflet number are the main characters that aid circumscribing species in the complex. Neither leaf venation nor leaf anatomy was examined in that study. Leaf venation patterns have been used successfully at high and low-level taxonomic ranks (e.g., angiosperms (Doyle, 2007); Anacardiaceae (Martínez-Millán and Ceballos-Ferriz, 2005); Gunneraceae (Fuller and Hickey, 2005); Sorbus, (Merrill, 1978)). As Doyle (2007) stated, a "closer examination of leaf characters in light of molecular relationships, including more detailed analysis of variation in their component features, should allow better definition of characters and reveal additional correlations of interest for both paleobotanists and neobotanists."

This study presents a comprehensive description of leaf anatomical and leaf architecture characters for the endemic GAB species of Bursera, as part of a taxonomic revision for the Greater Antilles and the Bahamas. Variation in leaf morphology and anatomy was examined in context of the phylogeny (Martínez-Habibe, in prep.) to reveal synapomorphies and character transitions. Of great interest is to determine whether variation in leaf venation and anatomy supports the molecular hypothesis of non monophyly of the GAB species B. angustata, B. inaguensis and B. glauca. A similar scenario of non-monophyly was found for three species in the $B$. simaruba complex ( $B$. itzae, B. ovalifolia, B. roseana) and a Cuban species identified as B. inaguensis by Rosell et al. (2010). After analyzing molecular and morphological evidence, these authors suggested that more data from fertile material are needed to test whether (1) B. itzae is the same entity as B. simaruba; (2) B. roseana is the same entity as B. attenuata, albeit showing slight variation with elevation, (3) B. attenuata is derived from B. roseana but with incomplete lineage sorting; and (4) the Cuban 
collection identified by them as $B$. inaguensis represents a distinct species.

Given their close relationship with GAB Bursera (Weeks et al., 2005; Rosell et al., 2010), some members of the $B$. simaruba complex are also included in the present study. Costa Rican $B$. standleyana and Colombian $B$. invers $a$ were sampled because, except for $B$. simaruba, they are the only species of the subgenus occurring in tropical rainforests, and their morphology and anatomy are expected to contrast with the GAB and Mexican species given Rzedowski's (1979) observations of Mexican Bursera. At first glance, there is a great deal of variation in leaf length among GAB species, including size $(\sim 1 \mathrm{~cm}$ long in $B$. spinescens to $>20 \mathrm{~cm}$ long in $B$. brunea $)$ and number of leaflets (uni- to 11-foliolate).

Comparing morphological and anatomical characters of species with simple (or unifoliolate) versus compound leaves raises questions of homology. In Bursera, the simple leaf is here considered homolgous with the terminal leaflet, that is, in this group each leaflet of a compound leaf is a reiteration. Indirect evidence for this hypothesis of homology is the developmental series found in B. angustata seedings, which show increasing leaflet number from 1 early in development to the mature condition of 7. In addition, some branchlets of unifoliolate Jamaican B. lunanii have 3-foliate leaves, the terminal leaflet of which is most similar to that of unifoliolate leaves (pers. obs.). 


\section{MATERIALS AND METHODS}

Sampling - This study includes all endemic species of Bursera subgen. Bursera in Cuba, Hispaniola, Jamaica and the Bahamas, plus widespread B. simaruba, B. inversa and B. standleyana. There are no endemic species of Bursera subgen. Elaphrium in the GAB nor does Bursera occur on Puerto Rico or the Lesser Antilles other than the widespread B. simaruba. A specimen described as B. trinitensis from Trinidad is of uncertain identity and is not included here (or that putative taxon is not treated here). Leaf samples were obtained from 94 collections made on expeditions to Hispaniola, Cuba and Jamaica; these include several collections of the widespread species $B$. simaruba and all but one of the species (B. frenningae) endemic to the Greater Antilles. Vouchered samples from the two Bahamian species (B. frenningae, B. inaguensis) were obtained from the living collection at Fairchild Tropical Botanical Garden. Additional samples were obtained with permission from herbarium collections at COL, MEXU and NY. Samples of species from Colombia, Costa Rica and Mexico were collected by collaborators in those countries. Whole leaves were collected in the field and immersed in FPA (18:1:1 50\% EtOH : formalin : propionic acid). When samples were from herbarium specimens or silica-dried samples (i.e., for out-group taxa), a hydration step was carried out with $10 \%$ Aerosol OT for 6 hours. The species sampled, as well as localities and voucher data are provided in Table 4. For the three non-monophyletic species, data were collected from specimens representing both terminals of each species.

Leaf Anatomy - The middle portion of the leaf (in unifoliolate taxa) or terminal leaflet (in species with pinnate leaves) was cut transversely into $4 \mathrm{~mm}$-wide segments and processed through the following dehydration and paraffin infiltration series: 70\% EtOH, 2 h; $90 \% \mathrm{EtOH}, 2 \mathrm{~h}, 95 \%$ EtOH, 2 h; 100\% EtOH with 1\% safranin overnight; 100\% EtOH, 2 h; 2:1 100\% EtOH : xylene, 2 h; 1:2 100\% EtOH:xylene, 2 h; xylene, 2h; xylene, 2h; 2:1 xylene:paraffin oil, 2 h; 1:2 
xylene:paraffin oil, $2 \mathrm{~h}$. Samples were moved to a $58 \mathrm{C}$ oven for two paraffin changes of $6 \mathrm{~h}$ each, followed by embedding on a paraffin embedding station (Leica EG-1160, Wetzlar, Germany). Transverse sections $12 \mu$ thick were cut using an American Optical 820 rotary microtome (Carl Zeiss, San Diego, California, USA) and mounted on slides as described in Columbus (1999). Sections were stained using a modified Sharman (1943) series and the Fast Green-Safranin methods. The Sharman protocol is as follows, modified with substitution of xylene for Histo-Clear (National Diagnostics, Atlanta, Georgia, USA) and a reduced time for the iron alum step: HistoClear, 10 min; Histo-Clear, 10 min; 1:1 Histo-Clear: 100\% EtOH, 5 min; 100\% EtOH, 5 min; 95\% EtOH, 2 min; 90\% EtOH, 2 min; 70\% EtOH, 2 min; 50\% EtOH, 2 min; 30\% EtOH, 2 min; $\mathrm{H}_{2} \mathrm{O}, 2$ min; $2 \%$ aqueous $\mathrm{ZnCl}_{2}, 1$ min; $\mathrm{H}_{2} \mathrm{O}, 10 \mathrm{sec} ; 1: 25,000$ aqueous Safranin O, 5 min; $\mathrm{H}_{2} \mathrm{O}, 5 \mathrm{sec} ; 10 \mathrm{~g}$ orange $\mathrm{G}+25 \mathrm{~g}$ tannic acid +20 drops $\mathrm{HCl}+0.2 \mathrm{~g}$ thymol $+500 \mathrm{ml} \mathrm{H}_{2} \mathrm{O}, 5 \mathrm{~min} ; \mathrm{H}_{2} \mathrm{O}, 5 \mathrm{sec} ; 1 \%$ aqueous iron alum, $10 \mathrm{sec}$ (continuously moving slide); $\mathrm{H}_{2} \mathrm{O}, 10 \mathrm{sec} ; 30 \% \mathrm{EtOH}, 5 \mathrm{sec} ; 50 \% \mathrm{EtOH}$, 5 sec; 70\% EtOH, 5 sec; 90\% EtOH, 5 sec; 95\% EtOH, 5 sec; 100\% EtOH, 5 sec; 100\% EtOH, 10 sec; 3:1 Histo-Clear:methyl salicylate, 2 min; Histo-Clear, 2 min; Histo-Clear, until removed for coverslipping with Cytoseal (Richard Allan Scientific, Kalamazoo, Minnesota, USA). Sections were examined with a light microscope and photographed using a SPOT digital camera (Diagnostic Instruments, Sterling Heights, Minnesota, USA). Permanent slides are deposited at Rancho Santa Ana Botanic Garden.

Leaf Architecture-Samples for leaf architecture consisted of two or three mature leaves for each species (again with each clade sampled for non-monophyletic species). As explained above, for species with compound leaves, the terminal leaflet was used. Two staining protocols were used independently for each species sample. Leaves were cleared following the method of Cristophel et al. (1975): leaves were submerged in $5 \% \mathrm{NaOH}$ at $54{ }^{\circ} \mathrm{C}$ for one to several days (solution changed if clouded). After the leaf or leaflet became transparent, it was rinsed three times with water and left in a water bath for $10 \mathrm{~min}$. Leaves were then bleached by immersion in $\mathrm{NaClO}$, 
commercial strength, for $20 \mathrm{sec}-10 \mathrm{~min}$ depending on thickness, followed by a water rinse and then water bath (10 min). Staining with Acid Fuchsin was as follows: Acid Fuchsin (1\%: 1 gr. of acid fuchisin, $1 \mathrm{ml}$ of Glacial Acetic Acid (HOAc), $100 \mathrm{ml}$ of distilled water), 12-24 h; 50\% EtOH, 10 $\min ; 70 \% \mathrm{EtOH}, 10 \mathrm{~min} ; 95 \% \mathrm{EtOH}+4$ drops of $\mathrm{HCl}, 10-30$ min (until mesophyll destained to clear white); 100\% EtOH, 30 min (twice); and 100\% EtOH, 24 h. Staining with Safranin was as follows: EtOH graded series (50\%, 70\%, 95\%), 30 min each; Safranin in 95\% EtOH (1 gr. Safranin + $100 \mathrm{ml}$ 95\% EtOH), overnight; 95\% EtOH, $10 \mathrm{~min} ; 95 \% \mathrm{EtOH}+4$ drops $\mathrm{HCl}, 30 \mathrm{~min} ; 100 \%$ $\mathrm{EtOH}, 30 \mathrm{~min}$ (twice); $100 \% \mathrm{EtOH}, 24 \mathrm{~h}$. Leaves were mounted on slides following Vasco et al. (in prep.) and using Caroplastic (Carolina, Biological Supply Company, Burlington, North Carolina, USA), as follows: 1:1 (CH3)2CO:100\% EtOH, $30 \mathrm{~min}$; (CH3)2CO, $30 \mathrm{~min}$ (twice); 1:1 (CH3)2CO: un-catalyzed polyester resin (Caroplastic), $3 \mathrm{~h}$; samples were removed from the resin bath and the remaining acetone allowed to evaporate, $30 \mathrm{sec}-1 \mathrm{~min}$; samples were mounted between sheets of acetate using catalyzed resin as mounting medium, left overnight, and polymerized at $55^{\circ} \mathrm{C}$ for $3 \mathrm{~h}$ or until hardened after which the acetate was removed. Mounted samples were photographed with a SPOT digital camera (Diagnostic Instruments, Sterling Heights, Minnesota, USA) and deposited at The New York Botanical Garden.

\section{Character coding and ancestral character reconstructions-Characters from leaf}

architecture were scored following Ellis et al. (2009). Leaf anatomy characters used were unifacial vs. bifacial leaves, distribution of stomata and resin canal distribution at the primary vein. Additional characters recorded were type of soil, habitat and inflorescence length. A data matrix with characters that varied among samples was constructed (Table 5), and character state transitions were reconstructed using the program MESQUITE v. 2.74 (Maddison and Maddison, 2009), estimated by Maximum Likelihood (Markov $k$ state 1 parameter model, which corresponds to Lewi's [2001] Mk model) over the Bayesian allcompat tree using a combined data matrix of five 
loci: ETS, PEPC, rps 16 intron, $r p s 16$-trnK intergenic spacer and $p s b A$-trnH intergenic spacer) inferred by the author (see chapter one).

\section{RESULTS AND DISCUSSION}

The data matrix discussed here contains morphological, anatomical and ecological data for 40 characters. Ancestral states were recovered for several characters and those with Maximum Likelihood probability for a particular character state greater than or equal to 0.95 are noted below (e.g., $p=0.95$ ), along with other characters which, may help species circumscriptions, despite lack of phylogenetic signal. Figures 6-8 and 9C-D illustrate some characters of taxonomic importance and Figure 9A-B, the hypothesized evolution of some characters.

Leaf architecture - As mentioned above, we are assuming homology between the lamina of taxa with unifoliolate leaves and the terminal leaflet of compound leaves.

A) Petiole length-Petiole length ranged from $0-10 \mathrm{~cm}$ long. In general, the two Antillean lineages, GAB-3 and GAB-13, both show reduced petiole length (all petioles are less than $6 \mathrm{~cm}$, except $B$. angustata $(8-9 \mathrm{~cm})$, compared with the species of the $B$. simaruba clade and B. standleyana $(6-9 \mathrm{~cm}$ long). Petiole length of 3-4 cm supports B. frenningae and B. inaguensis A as sister species.

B) Simple vs. compound leaves - The ancestral state for the GAB species of Bursera is pinnately compound leaves ( $p=0.95$, Fig. 9A). Taxa in the two GAB lineages (GAB-13 and GAB-3) evolved simple leaves five times independently: Jamaican B. lunanii (Fig. 6E), Hispaniolan B. spinescens (Fig. 6B) and B. trinitensis (Fig. 6D), Cuban B. shaferi (Fig. 6A) and B. gibarensis (Fig. 6G). Simple leaves also occur in some species of the B. simaruba complex (J. Rosell, pers. comm.), and species with simple leaves have evolved independently elsewhere within the genus (e.g., B. xoloxotzii and B. rupicola, 
from subgenera Bursera and Elaphrium, respectively; de la Luz et al., 2010; GuevaraFéfer, 2010).

C) Laminar area-Notophylls $\left(2,025-4,500 \mathrm{~mm}^{2}\right)$ are a synapomorphy for the Jamaican clade. The two smallest sizes, leptophyll and nanophyll $\left(<25 \mathrm{~mm}^{2}\right.$ and $\left.25-225 \mathrm{~mm}^{2}\right)$ are present in species that occupy tropical deciduous forests, especially xeric low scrub on karstic soils (B. spinescens, B. gibarensis, B. gracilipes, B. glauca, B. trinitensis and B. gibarensis).

D) Laminar shape-Several species exhibit plasticity in leaf form, making it difficult to find phylogenetic signals from laminar shape, except the following audtapomorphies: B. shaferi (distinctively and consistently lanceolate) and B. aromatica (ovate). Bursera gibarensis and B. angustata $\mathrm{A}$ and $\mathrm{B}$ have linear-elliptic shaped laminae, but the character state is homoplastic.

E) Leaf symmetry-There is no phylogenetic signal from this character. All terminal leaflets and unifoliolate leaves are symmetrical, rendering the character useless among unifoliolate species. There may be phylogenetic signal for symmetry considering lateral leaves. Especially the lateral leaflets of B. brunea, B. gibarensis, B. simaruba and B. laurihuertae (the latter two from the B. simaruba clade), and B. inversa are predominantly asymmetric medially. The lateral leaflets of $B$. hollickii, B. brunea, $B$. simaruba, B. laurihuertae and B. krusei (the latter three from the B. simaruba clade) are basally asymmetric.

F) Leaf apex- Apex shape is polymorphic within some species. The ancestral state for both Antillean clades, GAB-13 and GAB-3, is acute ( $p=0.98$ and 0.96 , respectively). Among the species sampled in this study, mucronate leaf apices only occur in GAB species (Fig. $6 \mathrm{H}$ ) and, although homoplastic, the state is diagnostic for B. frenningae, B. inaguensis $\mathrm{A}$ and $\mathrm{B}, \mathrm{B}$. angustata $\mathrm{A}$ and $\mathrm{B}$, B. glauca and B. sp. nov. In contrast, 
Mexican species belonging to the $B$. simaruba complex have leaves that are mostly caudate apically.

G) Leaf base-Base angle and shape vary within species, but the most common states are rounded with an obtuse angle. A cordate base is apomorphic for B. shaferi and a percurrent base is synapomorphic for the sister pair B. frenningae + B. inaguensis A.

H) Major secondary vein framework-The ancestral state is simple brochidodromous (Fig. 8A), with independent changes to festooned brochidodromous (B. frenningae) and festooned semi-craspedrodromous (B. spinescens -Fig. 8B). Major secondary veins are always decurrent to the primary vein among species sampled, and spacing is homoplastic (i.e., may be regular or irregular). Fimbrial (perimarginal) veins are absent in all species. It has been suggested that a brochidodromous secondary vein framework is primitive for angiosperms (Hickey and Doyle, 1972). Burseraceae always have pinnate venation and most often (festooned-) brochidodromous leaves (Daly et al. 2011).

I) Inter-secondary veins - Leaves of most taxa lack such veins, but the ancestral state is ambiguous. There are no inter-secondary veins in GAB B. brunea, B. frenningae, $B$. inaguensis, B. lunanii, B. spinescens, nor in B. simaruba complex members B. cinerea and $B$. arborea. When present, inter-secondary veins can be parallel to major secondary veins or perpendicular to the midvein. It is equally probable for the inter-secondary veins to be shorter or longer than the subjacent secondary vein and this variation seems uncorrelated with variation in other characters (e.g., inter-secondary vein frequency which is also homoplastic).

J) Intercostal tertiary vein fabric - This character is polymorphic in some species and is homoplastic across all sampled taxa. Bursera frenningae and B. inaguensis A have alternate intercostals that are percurrent (i.e., majority of tertiaries cross between 
secondaries with regular offsets near the middle of intercostal area), as well as admedially ramified (i.e., veins branch toward the midvein but also some cross between secondaries-Fig. 8C and 9C), whereas leaves of B. inaguensis B are only admedially ramified (i.e., veins branch toward the midvein only - Fig. 8F). The new species from Guantanamo, Cuba, has admedially ramified tertiary veins (Fig. 8D), whereas $B$. glauca has transversely ramified tertiaries (i.e., tertiary veins ramify and join a higher order vein -Fig. 8D). Interestingly, species with coriaceous leaves are admedially ramified and those with membranaceous leaves are transversely ramified or alternate percurrent. The reticulate pattern that possesses a higher density of tertiary veins was not observed in the endemic GAB species although it is present in B. simaruba complex species B. attenuata, B. krusei and B. simaruba.

K) Epimedial tertiaries-Presence of ramified epimedial tertiaries (i.e., inserted on midvein and branching toward leaf margin) is apomorphic for B. aromatic (Fig. 8E). Reticulate epimedial tertiaries are plesiomorphic, present in B. brunea, B. gracilipes, $B$. hollickii, B. shaferi and B. standleyana. Epimedial tertiaries are absent from the other ten species.

L) Quaternary vein fabric-Most species in GAB have freely ramifying quaternary veins. The only species with quaternary veins that reticulate are B. brunea, B. shaferi and $B$. simaruba complex members B. attenuata, B. krusei and B. simaruba. These species are not closely related indicating that this character evolved independently.

M) Areolation - Level of development of areoles is assigned according to the shape and number of sides of the smallest areas of leaf tissue that are surrounded by veins. All GAB species have poor to moderate development of areoles except $B$. hollickii and $B$. trinitensis (moderately developed), and B. shaferi (well developed). The ancestral state is optimized as equally likely poor, moderate or good development of areoles, and no 
character state supports any clade.

N) Free Ending Veinlets (FEVs) - All GAB and B. simaruba complex species have FEVs with multiple dichotomous branches (Fig. 8G). Each FEV terminates in a tracheoid idioblast, a club-shaped tracheal cell with spiral wall thickenings (Fig. 8H), common for many arid-zone Bursera Alliance taxa (Daly et al. 2011).

Compared to mainland species, GAB Bursera leaves tend to be reduced in size, with shorter petioles and fewer (1-3), smaller leaflets than their close relatives in Mexico. It is remarkable that simple leaves evolved five times independently in the Antilles since this is a rare condition in the genus overall (Rzedowski and Kruse, 1979). Whether these are simple or unifoliolate leaves needs to be clarified thorough developmental studies. A correlation between reduction in laminar size and drier environmental conditions was previously reported by Rzedowski and Kruse (1979) for Mexican species of Bursera, and this is evidenced in the GAB by $B$. spinescens, B. gibarensis, B. gracilipes, B. glauca, B. trinitensis and B. sp. nov. In contrast, characters of shape (symmetry, apical and basal shape) do not show patterns, although there are some apomorphic shapes in species with distinctive leaves (e.g., B. shaferi), and mucronate leaves arose in both GAB lineages. In Mexico, the only species found so far to have mucronate leaves is B. xoloxotzii (Guevara-Féfer, 2010).

Results of the leaf architecture study indicate that intercostal tertiary vein fabric among GAB species is consistently a combination of alternate precurrent and admedially ramified veins that do not form a net. This pattern has a relatively low density of veins and may be related to environmental conditions; it may also be linked to other characters such as freely ramifying quaternary vein fabric and poor to moderate areolation. To date, leaf artchitecture has not been studied for mainland species except the few members of the B. simaruba complex included here and more sampling is warranted. 
Leaf anatomy - Leaf anatomy of the species sampled is uniform except for the four characteristics defined below. All have a similar cuticle and an epidermis with no hairs. All have resin canals, but number differs among species. Below I discuss characters for which variation was found (also see Table 6).

A) Distribution of stomata- The ancestral state is bifacial leaves $(p=0.85$, Fig. $9 \mathrm{~B})$. The analysis indicates that unifacial leaves and isostomic stomatal distribution evolved independently in four GAB Bursera species: B. gibarensis, B. glauca, B. spinescens and $B$. sp. nov. These four species occur in xerophytic scrublands and their laminar size ranges from leptophyll to nanophyll. Two other species, B. trinitensis and B. gracilipes, occupy the same habitat and have the same laminar size but have bifacial leaves and amphistomatic stomatal distribution. Another character that correlates with unifacial leaves for most species is leaf thickness: B. gibarensis, B. glauca and B. spinescens and B. sp. nov. have coriaceous, somewhat succulent laminas ca. $200-380 \mu$ thick, whereas B. trinitensis and B. gracilipes have membranaceous leaves with laminas ca. $120-160 \mu$ thick.

B) Parenchyma-Palisade and spongy parenchyma vary in thickness among the GAB species (30-150 $\mu$ and $40-200 \mu$, respectively). The distribution of parenchymatic tissue in bifacial leaves follows the typical pattern (one palisade layer adaxially and one spongy layer abaxially, Fig. 7D) with some variation in size and density of cells. Each species with unifacial leaves, in contrast, showed a different distribution pattern of palisade and spongy parenchyma, as follows. Bursera gibarensis has two layers of palisade parenchyma, the adaxial palisade $80-100 \mu$ thick, 1-(2) seriate, the abaxial biseriate, each series ca. $24 \mu$ thick, and a tight spongy parenchyma ca. $20-25 \mu$ thick (Fig. 7A). Bursera glauca has a tightly packed adaxial palisade layer that is 1-seriate, $40-60 \mu$ thick, and an abaxial palisade layer that is 2-seriate, plus short palisade-like 
cells in the middle of the leaf, each series $30-40 \mu$ thick, and a spongy parenchyma ca. $75 \mu$ thick (Fig. 7B). Bursera spinescens has palisade parenchyma uniseriate on the adaxial side, $20-30 \mu$ thick and closely spaced, vs. 2-3-seriate on the abaxial side, 70 $90 \mu$ thick, and very tightly spaced, and spongy parenchyma well developed and lax, $60-70 \mu$ thick. Bursera aff. glauca has very tightly packed adaxial palisade layer that is 1-seriate, $60-90 \mu$ thick, and an abaxial palisade layer that is 3-seriate, plus short palisade-like cells in the middle of the leaf, each series $25-30 \mu$ thick, and spongy parenchyma ca. $75-90 \mu$ thick (Fig. 7C).

C) Resin canals-The ancestral state for the species sampled of B. subgen. Bursera is optimized as four resin canals ( $p=0.98$, Fig. 7E and 9D), one adaxial, one abaxial and two in the center of the leaf, all associated with the midvein. In the GAB species there can be as many as five (B. lunanii with an additional abaxial canal; B. gracilipes (with an additional adaxial canal, Fig. 7F) or six (B. hollickii, two additional abaxial canals), or reduced to three abaxial canals in B. frenningae and B. inaguensis $\mathrm{A}$ and $\mathrm{B}$, and only one in B. spinescens. One resin canal was also observed for Mexican B. grandifolia (Fig. $7 \mathrm{H}$ ) and B. hindsiana.

D) Crystals-All species of Bursera studied showed crystals of two types. The most abundant are spherical crystals, ca. $25-30 \mu$ in diameter. Less common are smaller, rectangular crystals, ca. $10-15 \mu$ long. Both types of crystals are distributed throughout the lamina and around the midvein (Fig. 7). This general pattern was observed for GAB species and several others (i.e., B. hindsiana, B. microphylla, B. grandifolia, B. schlechtendalii; B. tonkinensis, B. inversa, C. leptophloeos). However, some GAB species (B. frenningae, B. lunanii, B. shaferi) have a distinctively high density of both types of crystals around the primary vein that can be observed at lower magnifications and therefore can aid species circumscriptions. 
No phylogenetic relationships can be inferrred from crystals.

From leaf anatomy, some characters are important for species circumscription. Distribution of stomata and the number of resin canals are the most promising characters for taxonomic studies. It would be interesting to complement these findings with sections at the apex and base of the lamina, as well as through the petiole, to determine whether number of canals remains constant or decreases towards the apex of the leaf(let). In general, leaf anatomy for this group (and all Burseraceae) is under-investigated (Daly et al., 2011). It is an open field with promise for studying character evolution and aiding species circumscriptions.

Interesting apomorphic characters that might help identify species in the field and support the species circumscriptions have been identified in the course of this study. An example is the presence of ramified epimedial tertiaries in B. aromatica, which are conspicuous in fresh leaves.

No substantial differences in leaf morphology or anatomy were found to corroborate the evidence from phylogenetic analysis that $B$. angustata and $B$. inaguensis, as traditionally circumscribed, are both polyphyletic. Alternative explanations to that scenario include incomplete lineage sorting, hybrid introgression or insufficient informative characters from molecular data. In contrast, additional evidence was indeed found to separate the population of B. glauca from Guantanamo as a new species. 


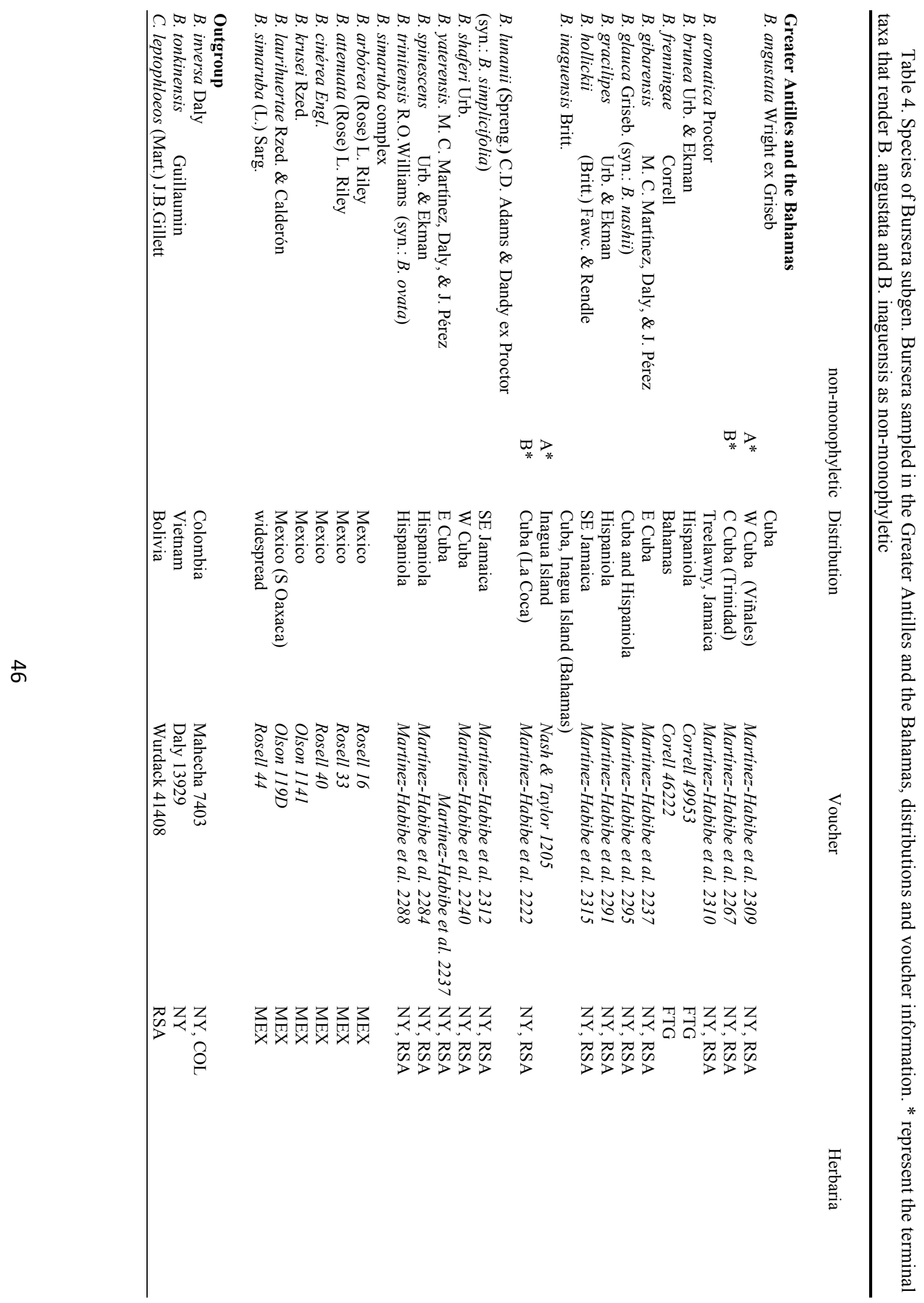




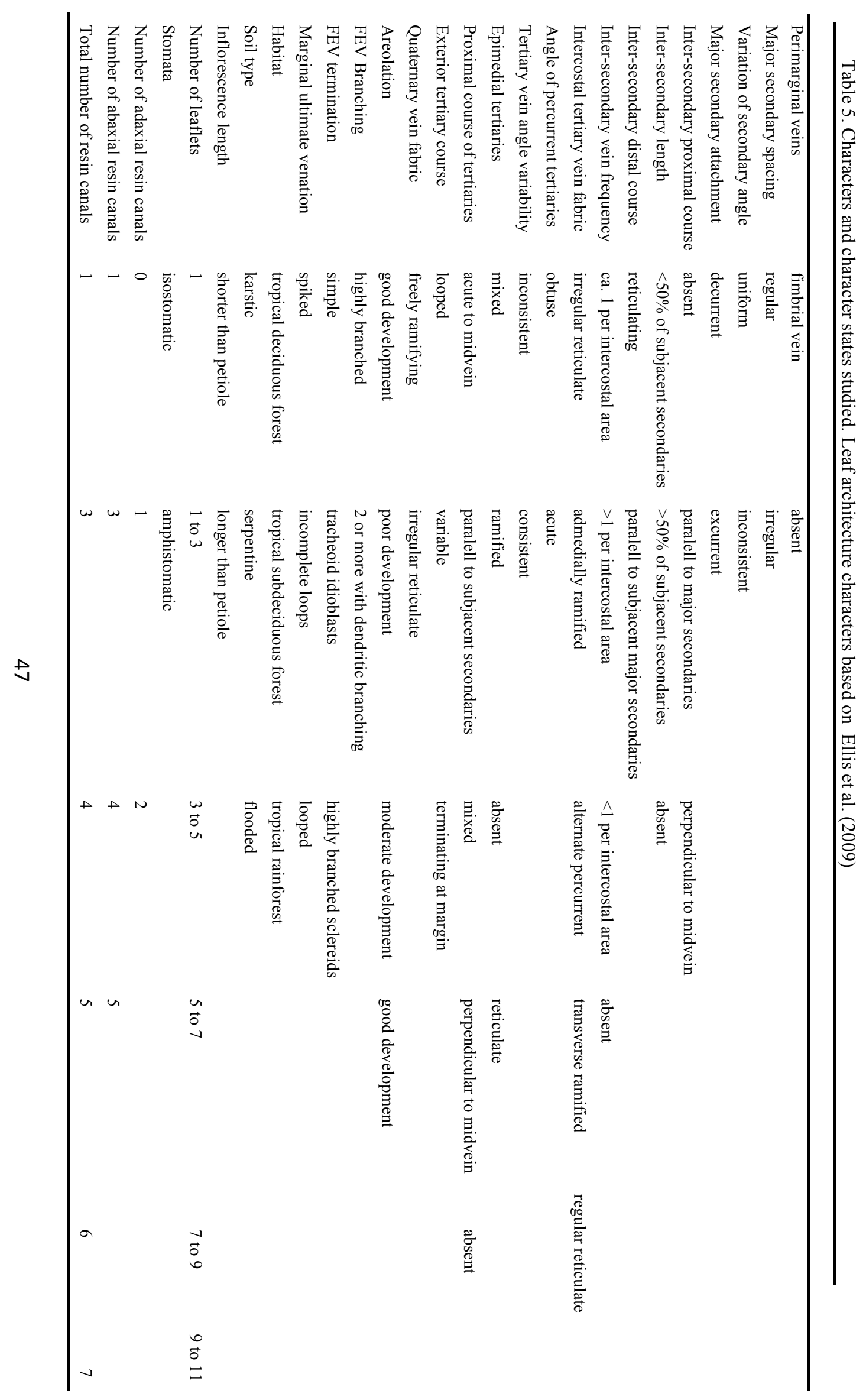




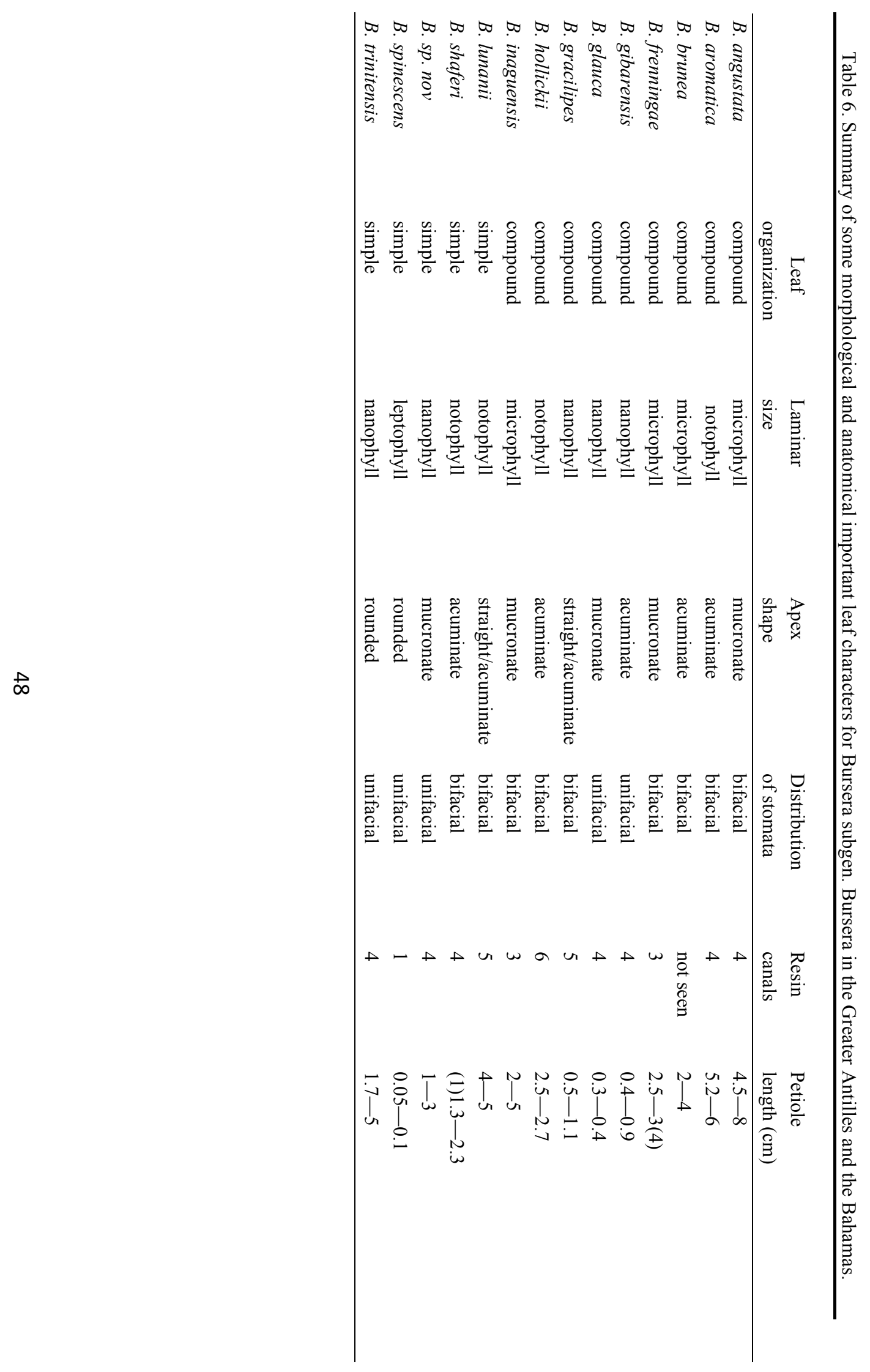




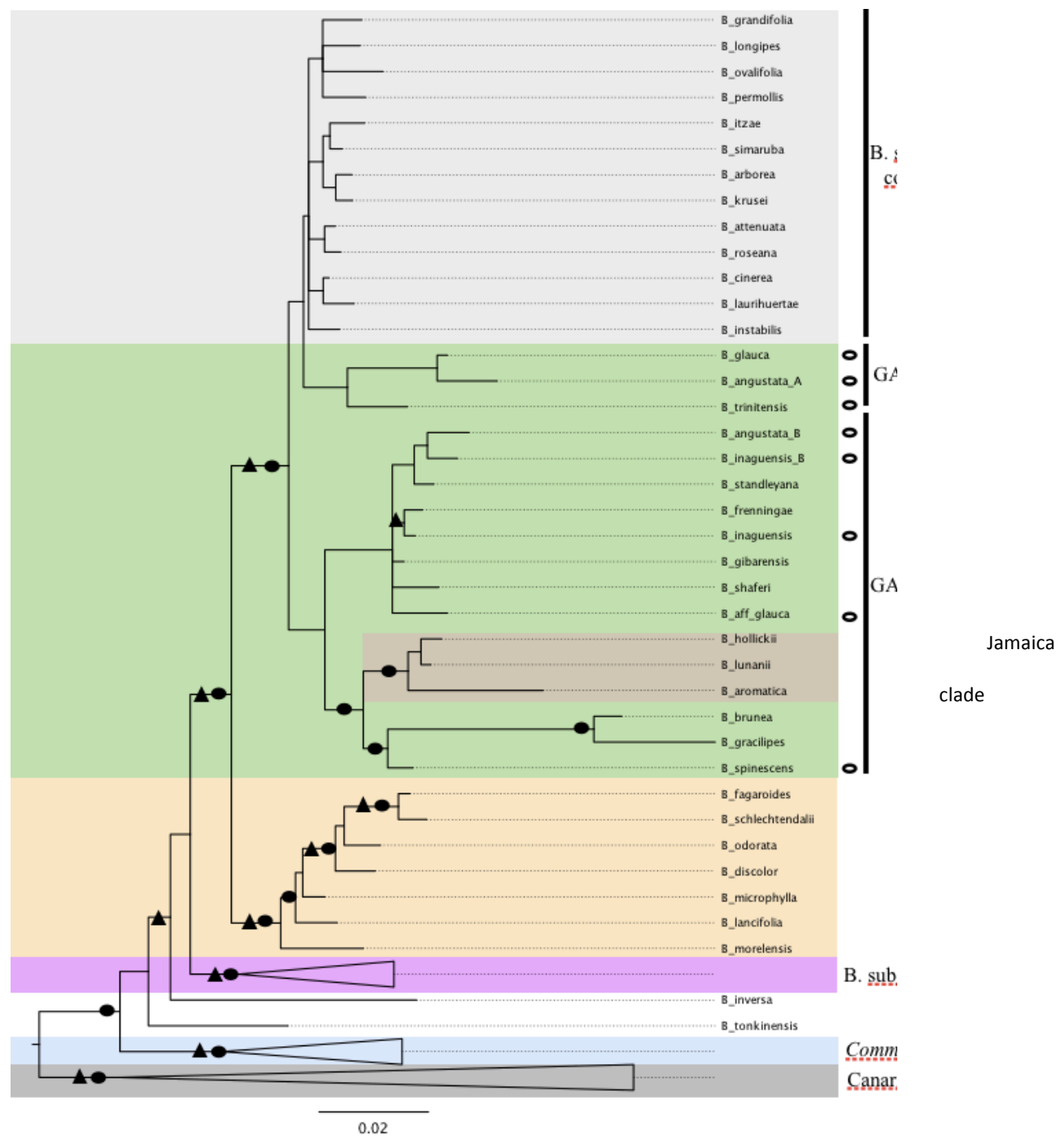

- $\mathrm{BPP}>0.95$

A $\mathrm{MPBP}>70$

Figure 5. Bayesian allcompat tree using a combined data matrix of five loci (ETS, PEPC, rps 16 intron, rps 16-trnK intergenic spacer and $p s b A$-trnH intergenic spacer). Colors represent the groups consistently recovered with independent loci. $\mathrm{BPP}=$ Bayesian posterior probability, $\mathrm{MP} \mathrm{BP}=$ Maxium parsimony bootstrap percentage. Open circle denotes species previously transferred to Commiphora. 

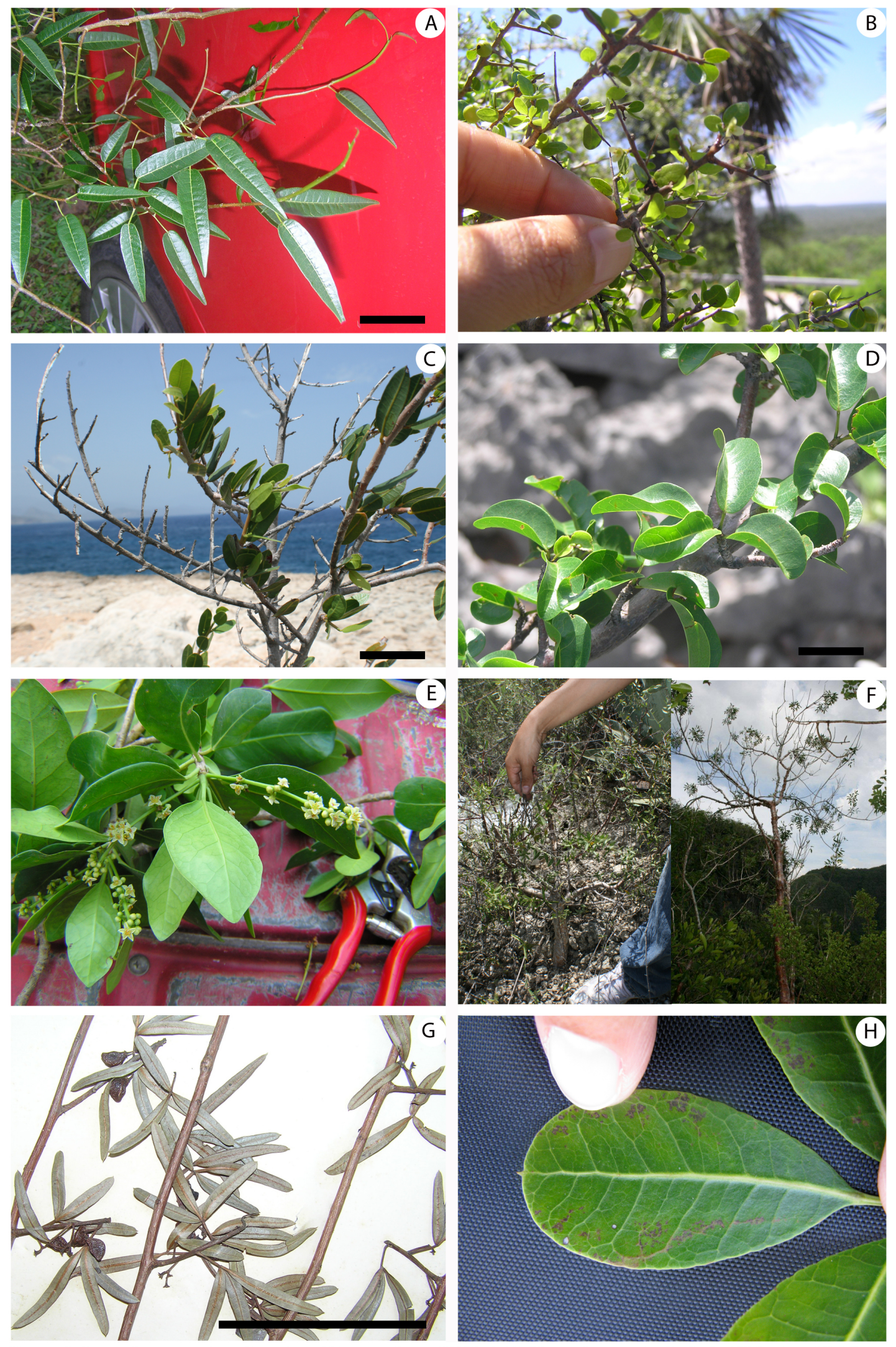

Figure 6. Some characteristics of species of Bursera in the GAB. A-E. Simple leaves. A. B. shaferi (Martinez-Habibe 2240, RSA). B. B. spinescens (Martínez-Habibe 2284, RSA). C. B. aff. glauca.(Martínez-Habibe 2237, RSA)

D. B. trinitensis (Martínez-Habibe 2288, RSA). E. B. lunanii.(Martínez-Habibe 2312, RSA)F. Habit of B. aff. glauca in E Cuba (left) and B. angustata A (right) in W Cuba (Martinez-Habibe 2309, RSA). G. B. gibarensis is distinctively 3-foliolate (Martinez-Habibe 2237, RSA).F. Mucronate apex in B. frenningae (Martinez-Habibe 2359, RSA).Scale bar $5 \mathrm{~cm}$ 
A
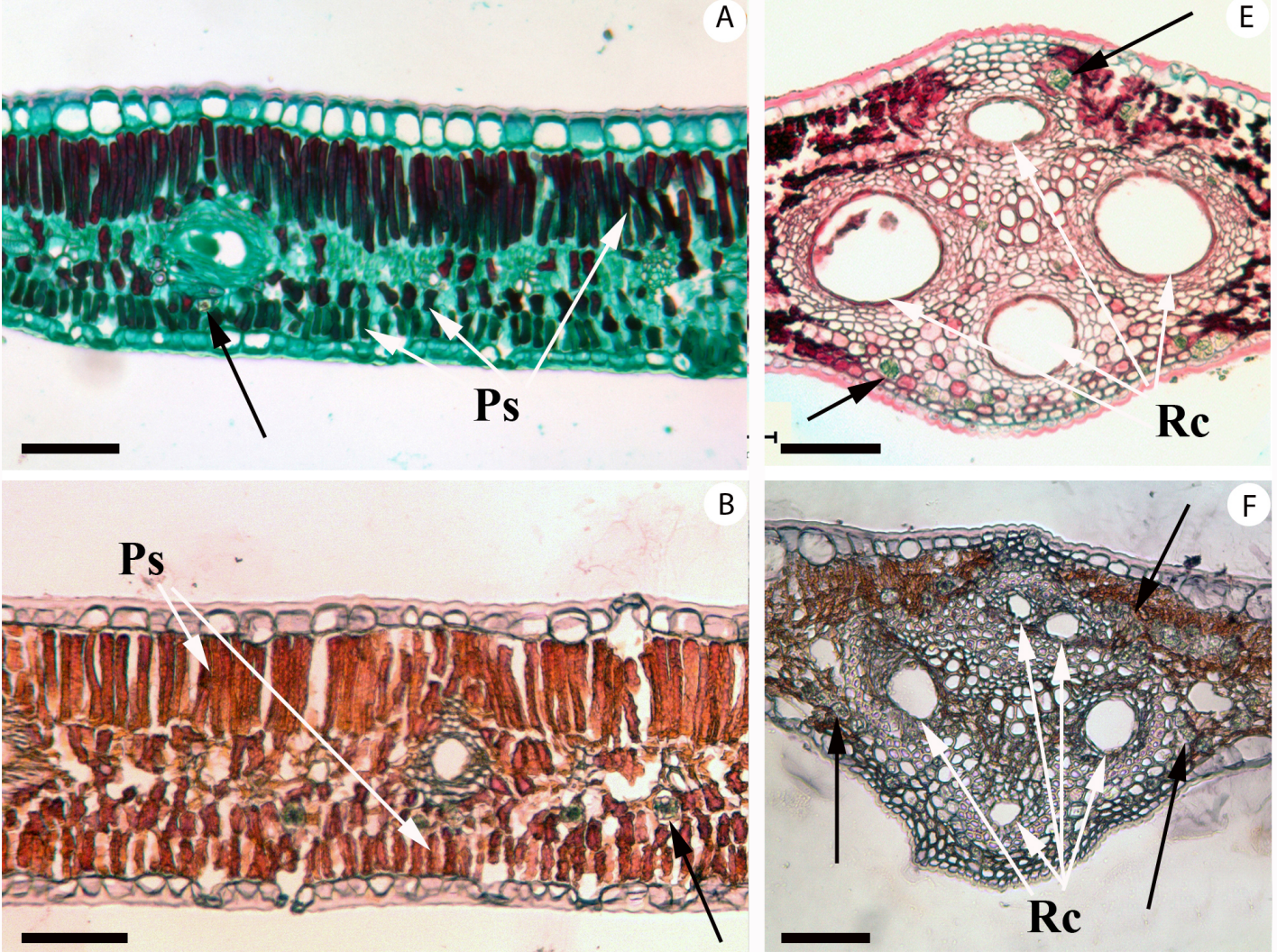

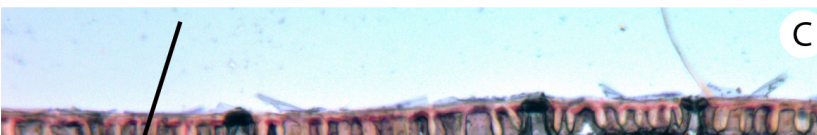

\section{(c)}

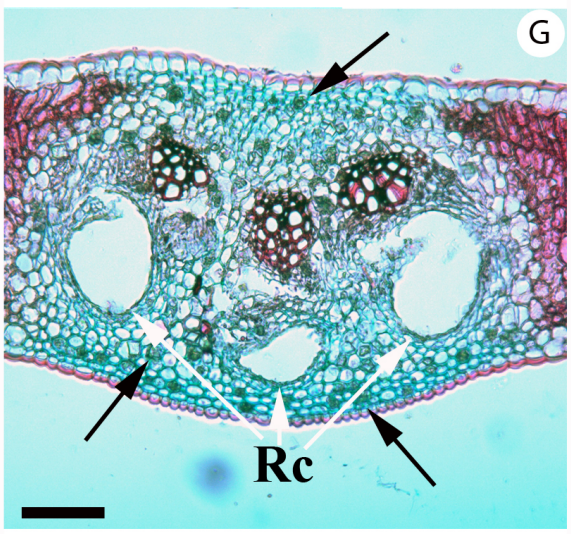

Ps

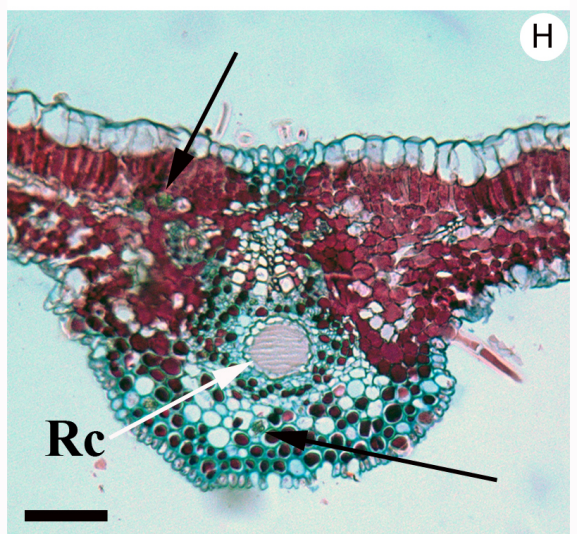

Figure 7. Microsections of the middle lamina of the leaf or terminal leaflet. A-C. Bifacial, amphistomatic leaves. A. B. gibarensis (Martinez-Habibe 2307, RSA). B. B. glauca (Martínez-Habibe, 2298, RSA). C. B. aff. glauca (Martinez-Habibe 2308,RSA).D. Isostomatic B. aromatica (Martinez-Habibe 2310, RSA). E-H. Variation in the number of resin canals. E. Four canals in B. glauca (Krosnick 615, RSA). F. Five canals in B. gracilipes (Martínez-Habibe 2291, RSA). G. Three canals in B. inaguensis (Martínez-Habibe 2358, RSA). H. One canal in B. grandifolia (Rosell 5, RSA). White arrows point to palisade parenchyma (Ps) and resin canals (Rc). Black arrows point to crystals. Scale bar $100 \mathrm{um}$. 

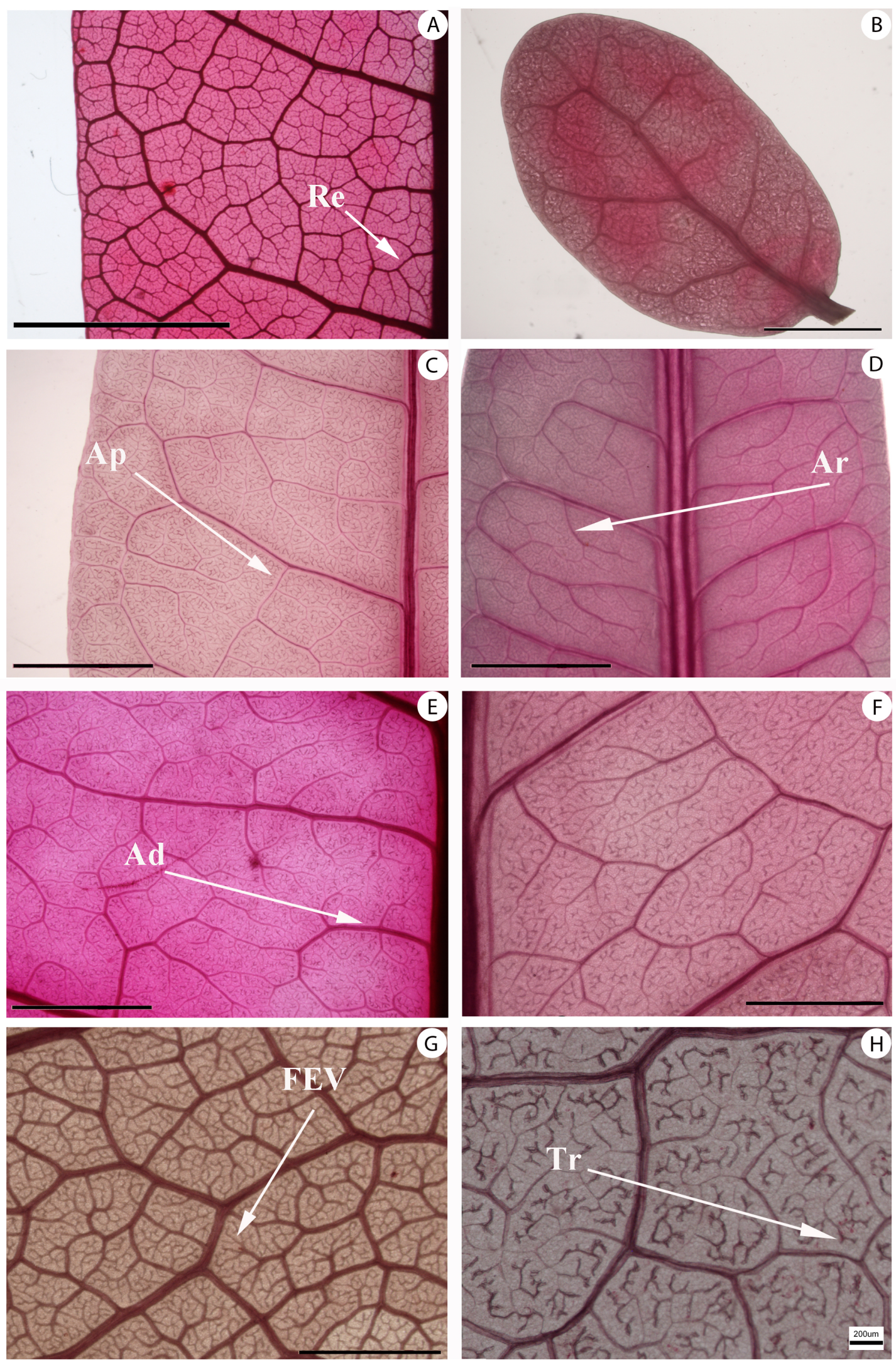

Figure 8. Leaf architecture of Bursera in the GAB. A-B. Major secondary framework. A. Simple brochidodromous (B. shaferi,

Martínez-Habibe 2240, RSA). B. Festooned semi-craspedrodomous (B. spinescens, Martinez-Habibe 2284, RSA). C-D. Intercostal tertiary vein fabric. C. Alternate percurrent and admedially ramified (B. inaguensis A, Nash\&Taylor 1205, RSA). D. Admedially ramified (B. aff. glauca, Martínez-Habibe 2232, RSA). E. Ramified epimedial tertiary veins (B. aromatica Martinez-Habibe 2310, $R S A)$. F. Freely ramifying quaternary vein fabric (B.inaguensis B, Martinez-Habibe 2222, RSA). G. Freely ending veinlets (FEV) branching $>2$ times (B. simaruba, Rosell 40,RSA). H. FEV ending in a tracheoid idioblast (B. hollickii, Martinez-Habibe 2315, RSA) Intercostal tertiary veins: $\mathrm{Ap}=$ alternate percurrent (tertieries cross between secondaries), $\mathrm{Ar}=$ admedially ramified (branching toward the midvein). Epimedial tertiary veins: $A d=$ admedially ramified (branch toward the leaf margin), $R e=$ reticulate. $\mathrm{Tr}=$ tracheoid idioblast. Scale bars at left $=5 \mathrm{~mm}$. Scale bars at right $=2 \mathrm{~mm}$, except on $\mathrm{H}(200 \mathrm{um})$. 


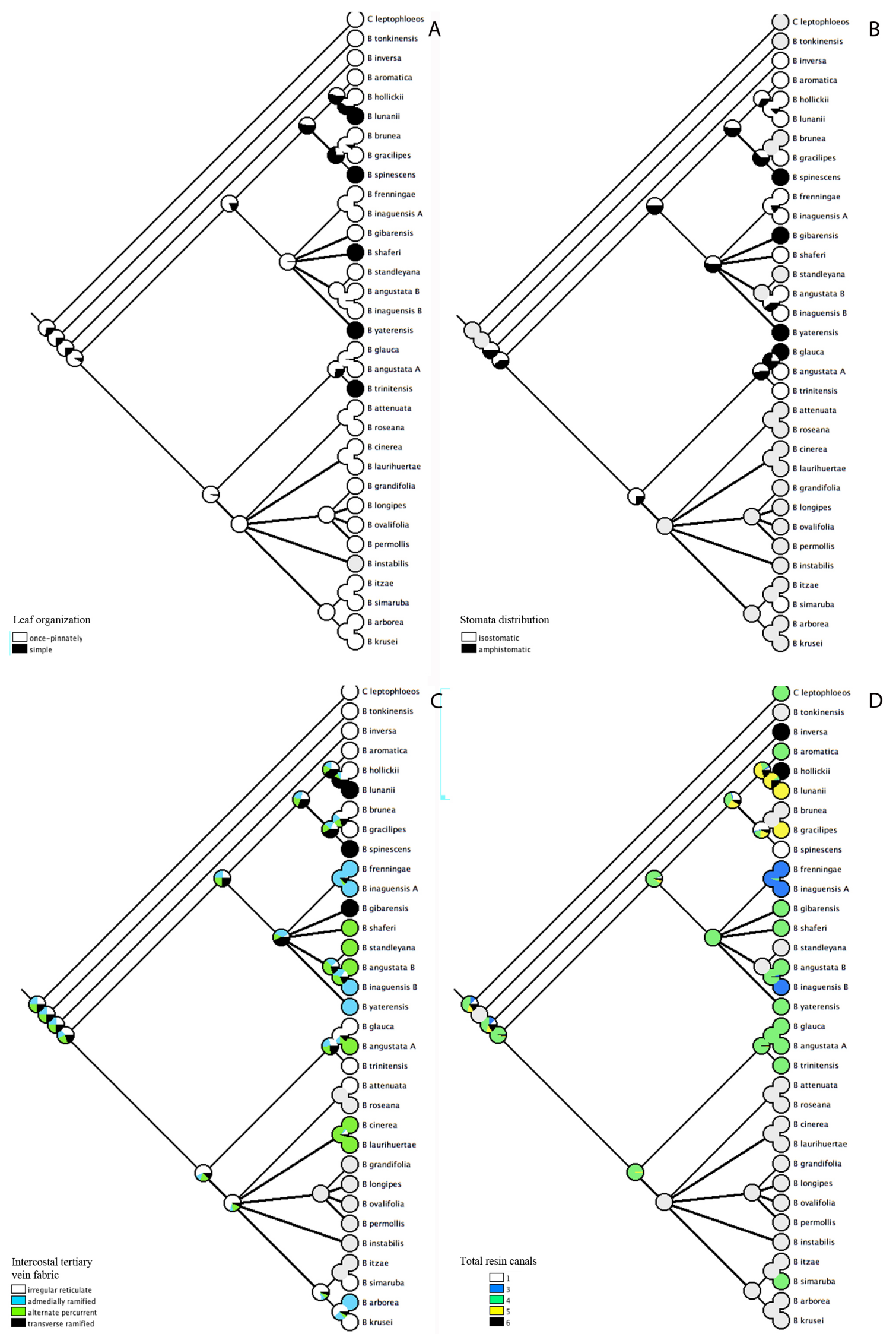

Figure 9. A-B. Ancestral reconstructions for some characters of Bursera in the GAB. A. Simple leaves evolved from compound leaves five times, independently.B. Unifacial leaves evolved from bifacial leaves four times. C-D. Distribution of characters with taxonomic importance.

C. Intercostal tertiary vein fabric. D. Total number of resin canals at the middle of the lamina. 


\section{Chapter three: A taxonomic revision of Bursera subgen. Bursera in the Greater Antilles and the Bahamas.}

\section{INTRODUCTION}

Bursera is a neotropical genus of shrubs and trees distributed mostly in seasonally dry tropical forests (SDTF) and xeric shrublands from the southwestern United States to Central America, the Caribbean, and northern South America (Colombia, Venezuela, southwestern Ecuador, northwestern Peru and central and extreme northern Brazil). Bursera has ca. 106 species in all, ca. 80 of them endemic to Mexico (Rzedowski and Guevara-Féfer, 1992); the Balsas River watershed alone is home to 48 species (Rzedowski et al., 2005). There has been much research on the taxonomy of the Mexican species of Bursera (Rzedowski and Kruse, 1979; Rzedowski et al., 2004, 2005; Rzedowski and Calderón, 2006), especially in the past decade during which at least 13 species have been described (Rzedowski and Calderón, 2000a,b, 2002, 2006; Rzedowski et al., 2007; Rzedowski and Rzedowski, 2008; de la Luz and Pérez-Navarro, 2010; Guevara-Féfer, 2010). Moreover, the South American species are reasonably well worked out (Daly, in press). After Mexico, the region of highest diversity of Bursera species is the Greater Antilles and the Bahamas; all but one of 15 species in this area are in Bursera subgen. Bursera. No studies have focused on taxonomy, morphology or anatomy of Bursera in this region except for a wood anatomy study of two Bahamian species (Stevenson, 1979). Information about the endemic species is scattered and consists of incomplete species descriptions or listings in local floras, therefore identification of Bursera in the GAB is difficult.

Phylogenetic relationships above the genus level are unresolved. According to Daly et al. (2011), the Bursera Alliance is composed of Aucoumea and Bursereae subtribe Burserinae 
(Bursera and Commiphora). The Bursera Alliance is morphologically conservative (e.g., leaves exstipulate, petals distinct, pollen with short colpi, fruits dehiscent acropetally), which has led to a good deal of confusion at generic and subgeneric ranks. Only a few morphological characters separate Bursera and Commiphora as currently circumscribed. Gillett (1980) kept the genera separate on the basis of the former having branches only rarely spinose (vs. spines often present), stamens in two (sub)equal series (vs. inner whorl usually shorter so that the two whorls do not overlap), distinct pseudaril shape and distribution on the pyrene surface, and calyx shallow with lobes open (apert) in bud (vs. closed in bud), although only the apert calyx was consistently diagnostic. In practice, generic assignment is often based on geography: Bursera is New World, except for poorly knownVietnamese $B$. tonkinensis, while Commiphora is Old World except South American C. leptophloeos and five Antillean species treated here as misplaced in Bursera. Chromosome numbers have been reported for very few species, but so far are consistently different (Bursera $2 n=24$, Commiphora $2 n=26)($ Fedorov, 1966).

The two subgenera of Bursera are each monophyletic in molecular phylogenetic analyses, but some studies suggest that subg. Elaphrium is sister to Commiphora + B. subg. Bursera (Weeks et al., 2005; Weeks and Simpson, 2007), while other studies support the monophyly of Bursera (Becerra, 2003; Rosell et al., 2010). In the most comprehensive phylogenetic study to date, with nearly all Mexican species of Bursera sampled, combined analysis of five markers (ETS, PEPC, psbA-trnH, rps16-trnK, rps16) rendered Bursera monophyletic, but separate analyses of ETS and PEPC loci still supported a sister relationship between Bursera subg. Bursera and Commiphora (De-Nova et al., 2011). A recent phylogenetic study (discussed below) that focused on relationships among species of Bursera from the Greater Antilles and the Bahamas archipelago (GAB) and their mainland relatives (see chapter one) reached the following conclusions:

1. Relationships between the two genera remain unresolved; 
2. Two separate lineages from Central America colonized the islands during the Miocene;

3. Five Antillean species previously transferred to Commiphora (Moncada-Ferrera, 1989; Borhidi, 1997) are nested within Bursera; the only valid species of Commiphora in the Neotropics is C. leptophloeos (Mart.) J. B. Gillett); and

4. Two species are not monophyletic (i.e., B. angustata Wright ex Griseb., B. inaguensis Britt.).

A third species, B. glauca Griseb. appeared as not monophyletic on the molecular phylogeny, but anatomical and morphological evidence made possible the identification of one of these accessions as a new species, B. yaterensis, described below.

\section{TAXONOMIC REVISION}

Materials and methods — Data from literature, field samples and specimens from 19 herbaria were used to construct species descriptions. Results from study of leaf architecture and anatomy (chapter two) are used here as additional diagnostic characters that aid species circumscriptions. Specimens used for this study belong to the following herbaria: F, FTG, G, GOET, H, HAC, HAJB, HMC, HUH, IJ, JBSD, K, LL, MO, NY, RSA, S, UPRRP, US.

Botanical and Taxonomic History—Botanical surveys of the West Indies were conducted as early as the late 1600's by Plumier (French colonies) and Plukenet and Sloane (British colonies) (Acevedo-Rodríguez and Strong, 2008). Afterwords, four prolific botanists collected extensively in the region and described several species of Bursera. Charles Wright made several trips to Cuba from 1856 to 1867. August Grisebach described species of Bursera in his Plantae Wrightianae e Cuba Orientali (1860-1862). Nathaniel Lord Britton conducted at least 30 botanical expeditions to the West Indies that resulted in 27 publications from 1901-1926. Ignaz Urban made the first effort to describe the flora of Hispaniola and, along with Erik Ekman, who traveled particularly to Haiti 
between 1914 and 1931, published more than 600 new species. More contemporary contributions to the genus Bursera came from Correll (1979) for the Bahamas archipelago and Proctor (1982) for Jamaica. Recently, three Cuban and two Hispaniolan species of Bursera were transferred to Commiphora (Moncada-Ferrera, 1989; Borhidi, 1992), but a molecular phylogenetic recostruction with comprehensive sampling resolved that those species really belong in Bursera (see chapter one). Two new species of Bursera have been recentlydiscovered, one of them, B. gibarensis from eastern Cuba (Martínez-Habibe et al., in press), and B. yaterensis, described here.

\section{Bursera Jacq.}

Bursera Jacq. ex L., Sp. Pl. ed. 2, 1: 471 (1762), nom. cons., Rzedowski et al., Acta Bot. Mex. 70: 85-111 (2005). Terebinthus P. Browne (1756). Elaphrium Jacq. (1760).

(Polygamo-)dioecious shrubs to large trees, sometimes caudiciform, rarely lithophytic or epiphytic; bark papery and peeling or close; resin clear or translucent, ?aromatic?; branchlets usually unarmed. Cataphylls sometimes present; leaves usually clustered near branchlet apices, usually deciduous, imparipinnate or sometimes unifoliolate, rarely bipinnate; rachis often winged; petiolules lacking pulvinuli; leaflets entire, crenate, or dentate, freely ending veinlets often with tracheoid idioblasts. Inflorescences axillary or subterminal and paniculate or sometimes pseudospicate, pseudofasciculate, or pseudoracemose. Flowers unisexual or less often bisexual, in subg. Bursera male flowers (3-4)5- merous, female and bisexual flowers 3-merous, in subg. Elaphrium flowers 4-merous; receptacle flat to saucer-shaped, rarely cup-shaped, sometimes forming a hypanthium in male flowers; calyx usually divided almost to base, apert; corolla induplicate-valvate at apex but slightly imbricate along margins, usually with inflexed apiculum; stamens in two usually subequal series; pistillode greatly reduced, with rudimentary locules and ovules, or sometimes spindle-shaped and parenchymatous, occasionally obsolete; disk intrastaminal, usually annular, sometimes adnate to hypanthium (when latter present); gynoecium 3- 
carpellate (subg. Bursera) or 2-carpellate (subg. Elaphrium); style usually short, stigmas or stigma lobes $3-2$. Fruit a septicidally dehiscent compound drupe with fleshy to coriaceous pericarp, ellipsoid to (ob)ovoid or subglobose, often slightly oblique; at dehiscence 2-3 valves (= number of locules) fall away, exposing the basifixed compound pyrene(s); pyrene cartilaginous to bony, either enveloped by a brightly colored, fleshy, arillate structure (subg. Bursera), or the arillate structure partially covering the pyrene from the base and extending arms or lobes up the sutures (most of subg. Elaphrium); 1(-3) locule (s) developing a seed, the other(s) abortive, these not separable from fertile locule but often distinguishable by a ridge or furrow. Testa membranaceous, cotyledons palmately 3-lobed or usually multilobed, folded. Germination epigeal, phanerocotylar, first eophylls alternate and simple. $\mathrm{n}=12$.

Approx. 106 species from SW U.S.A., Mexico (center of diversity), Central America, Caribbean, Colombia, Venezuela, Trinidad, Guyana, SW Ecuador, NW Peru, extreme N Brazil (Roraima), and central Brazil (Goiás).

Seems a bit jump here from overall genus (big picture) to now just GAB ones. Needs a tiny transition?

Key to the species of Bursera in the Greater Antilles and the Bahamas

1. Leaves clustered at the tips of the branches; leaf rachis narrowly winged; leaflet margin serrate B. graveolens (subgen. Elaphrium)

1. Leaves not clustered at the tips of the branches; leaf rachis exalate; leaflet margin entire ..... 2

2. Suffrutices to $30 \mathrm{~cm}$ tall B. gibarensis

2. Shrubs or trees 3

3. Outer bark red or reddish and peeling in papery sheets 4

4. Leaves unifoliolate, lanceolate, base cordate, very rarely some leaves 3-foliolate B. shaferi

4. Leaves 3-11-foliolate .5 
5. Lateral petiolules 3-8 mm long; leaflet apex rounded, apex tip acuminate; lateral leaflets oblong to ovate or elliptic; terminal leaflet oblong to oblanceolate; mature fruits $9-15 \mathrm{~mm}$ long. B. simaruba

5. Lateral petiolules 0.5-1.5 mm long; leaflet apex acute or rounded, apex tip mucronate; lateral leaflets lanceolate-elliptic or broadly oblong-elliptic to ellipticoblanceolate; terminal leaflet lanceolate-elliptic to oblanceolate; mature fruits $<9$ mm long 6

6. Leaves 8-10 cm long, 3-5(7)-foliolate; petiole 2.5-3(4) cm long; lateral leaflets sessile or the petiolules $0.3-0.5 \mathrm{~mm}$ long; lateral leaflets $1.9-2.2 \mathrm{~cm}$ wide, broadly oblong-elliptic to elliptic-oblanceolate, terminal leaflet 6.1-6.3 x 2.1-2.3 cm; open coppices and coastal thickets in the Bahamas ... B. frenningae 6. Leaves 7.1-14.5 cm long, 7-11-foliolate; petiole 4.5-8 cm long; lateral petiolules $0.5-1.5 \mathrm{~mm}$ long; lateral leaflets $0.6-0.9 \mathrm{~cm}$ wide, lanceolate-elliptic to oblanceolate, terminal leaflet $3-6 \times 0.9-1.3 \mathrm{~cm}$; low thorn scrub in W Cuba B. angustata

3. Outer bark gray or grayish to brown, close or shed in plates (not papery) 7

7. Outer bark rough, shed in plates B. lunanii

7. Outer bark close and smooth. .8

8. Leaves simple ................................................... 9

9. Leaves agglomerated in short shoots, 10

10. Plants highly branched, branch apices thorn-like; petiole $0.5-1 \mathrm{~mm}$ long, lamina 5-10 mm long, oblong-elliptic, apex and base rounded, lamina almost succulent B. spinescens

10. Plants sparsely branched, branch apices not thorn-like; petiole 1.7-5 $\mathrm{mm}$ long, lamina 1.5-2.5 cm long, ovate, apex obtuse, base rounded, lamina membranaceous B. trinitensis (syn.: B. ovata)

9. Leaves not agglomerated in short shoots; midvein broadly prominulous ... 


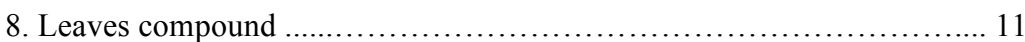

11. Leaves $2-6 \mathrm{~cm}$ long, sessile or petiole to $11 \mathrm{~mm}$ long 12

12. Leaves 3-6 cm long, 1-5(7)-foliolate; petiole 3-4 mm long; leaflets chartaceous, laterals 38-42 mm long, narrowly oblong-elliptic to oblong, terminal leaflet 39-43 mm long, oblong-elliptic to slightly oblanceolate, apex obtuse, short-acuminate or mucronate, base acute to rounded; Cuba and Hispaniola B. glauca (syn.: B. nashii)

12. Leaves 2-3 cm long, (1)3-5-foliolate; petiole 5-11 mm long; leaflets membranaceous, laterals $17-22 \mathrm{~mm}$, oblongelliptic, terminal leaflet 13-23 mm, narrowly (oblong-)elliptic or slightly oblanceolate, apex acuminate, acumen to $3.5 \mathrm{~mm}$ long, base acute or slightly obtuse; Hispaniola ... B. gracilipes

13. Leaves $19-23 \mathrm{~cm}$ long, 3-5-foliolate; petiole $5.2-6 \mathrm{~cm}$;

B. aromatica

13. Leaves $8-12 \mathrm{~cm}$ long, $3-7$-foliolate; petiole $2-5 \mathrm{~cm} \ldots . .14$

14. Leaves ovate to oblong; lateral petiolules $4-6 \mathrm{~mm}$ long; lateral leaflets $3.5-4.1 \mathrm{~cm}$ long; Jamaica B. hollickii

14. Leaves oblong-elliptic, elliptic, obovate, oblanceolate or lanceolate-elliptic; lateral petiolules $0.3-0.7 \mathrm{~cm}$ long; lateral leaflets 4-5 cm long; Bahamas, Cuba and Hispaniola 15

15. Terminal petiolule $6-7 \mathrm{~mm}$, lateral leaflets $1.6-$ 
$1.9 \mathrm{~cm}$ wide, lamina medially asymmetric, oblongelliptic to elliptic; terminal leaflet $2.1-2.5 \mathrm{~cm}$ wide, obovate; leaflet tip acuminate, acumen 6-7 $\mathrm{mm}$ or sometimes obtuse; leaflets chartaceous; Hispaniola B. brunea

15. Terminal petiolule $3.5-4.5 \mathrm{~mm}$; lateral leaflets $0.9-1.3 \mathrm{~cm}$ wide, lamina symmetric, oblong to oblanceolate; terminal leaflet $1.4-1.9 \mathrm{~cm}$ wide, lanceolate-elliptic to oblanceolate or sometimes obovate; leaflet tip mucronate; leaflets coriaceous; Cuba and Bahamas B. inaguensis

Would you want to indicate which are GAB endemics (and which clade) and which are B sim complex taxa? Would seem to be useful (to me)

Bursera angustata Wright ex Griseb., Cat. P1. Cub.[Grisebach]65. 1866. Terebinthus angustata

(Griseb.) Britton, Bulletin of the Torrey Botanical Club 35: 342. 1908. Elaphrium angustatum

(Griseb.) Rose, North American Flora 25(3): 245. 1911. Commiphora angustata (Griseb.)

Moncada, Revista del Jardín Botánico Nacional, Universidad de la Habana 10(1): 3-10. 1989.

Type. Cuba: (without location)(without date/1860-1864?), C. Wright 2278 (lectotype

[designated here]: K; isotypes: BM, GOET, HAC, HAJB, MO, NY, S).

Tree, 4-5 m tall, dioecious. Trunk monopodial. Bark red, peeling in thin papery sheets. Trichomes (when present on inflorescences and calyx) consisting of erect fine hairs to $0.4 \mathrm{~mm}$ long. Leaves $7.1-14.5 \mathrm{~cm}$ long, $7-11$-foliolate; petiole $4.5-8 \mathrm{~cm}$ long, terete; lateral petiolules $0.5-1.5$ $\mathrm{mm}$ long, terminal petiolule 3-9 $\mathrm{mm}$ long; lateral leaflets $2.6-6.3 \mathrm{~cm}$ long, lanceolate-elliptic, terminal leaflet 3.0-6.0 cm long, lanceolate-elliptic to oblanceolate; leaflet apex acute or sometimes rounded, mucronate; base of lateral leaflets symmetric (sometimes asymmetric), acute to cuneate or 
rounded; base of terminal leaflet decurrent; margin flat; leaflets coriaceous, dull, on abaxial surface the midvein pale yellow, lamina green, secondary veins inconspicuous, drying brown abaxially and (blackish-)brown adaxially; on adaxial surface the midvein and secondary veins pale yellow. Pistillate inflorescences (staminate unknown) (5.5)9-11 cm long, 1.2-1.6 mm diam, longer than petiole of subtending leaves, with secondary axes to $4 \mathrm{~cm}$ long, glabrous or with scattered hairs. Bracts subtending inflorescences $0.5-1 \mathrm{~mm}$ long, deltate and deciduous; bracteoles subtending cymules or flowers $0.5-0.8 \mathrm{~mm}$ long, deltate, with hairs as on inflorescence (when present). Pistillate flowers $6.5-7.8 \mathrm{~mm}$ long; calyx $2.6-3.7 \times 3.2-4.1 \mathrm{~mm}$, taller than the disk, cupular, the lobes $1.8-2.1 \mathrm{~mm}$ long, lanceolate to deltate; petals $6.5 \times 2.9 \mathrm{~mm}$, lanceolate to ovate, with an inflexed apiculum $0.3 \mathrm{~mm}$ long; staminodes in two equal series, $3.4-3.5 \mathrm{~mm}$ long with oblong anthers $1.4-1.7 \mathrm{~mm}$ long; disk $0.4-0.9 \mathrm{~mm}$ tall, $0.2-0.4 \mathrm{~mm}$ thick, glabrous; pistil $3.4-3.5 \mathrm{~mm} \times 2.2$ $\mathrm{mm}$, ovoid, the style narrow and short, $0.6 \times 0.5 \mathrm{~mm}$, the stigma 3-lobed. Fruits $7-8 \times 5 \mathrm{~mm}$, globose, pedicel clavate, $1.3-3 \mathrm{~mm}$ long, mature exocarp green except slightly red at the apex, smooth, dehiscing via three valves, pseudaril bright orange-red, thin, covering the entire pyrene; pyrene 6 × 3.5-4.5 mm, subglobose, trigonous with flat sides, beige. Germination epigeal. Seedlings with palmately 3 -fid cotyledons.

Leaf anatomy.-Leaves isostomatic, lamina with pallisade and spongy parenchyma welldeveloped. Crystals of two types, rhomboid and hexagonal, distributed throughout the lamina but especially around the primary vein. Primary vein with one adaxial and three abaxial resin canals.

Distribution and ecology.-Bursera angustata occurs in the western provinces of Cuba in low thorn-scrub associated with serpentine soils (cuabal), dogtooth limestone and ultramafic slopes. Common associated species are Plumeria emarginata Griseb., Erythroxylum havanense Jacq., Gymnanthes lucida Sw., Phyllanthus epiphyllantus L., Tabebuia myrtifolia (Griseb.) Britton, Cordia gerascanthus L., Tillandsia fasciculata Sw., Croton lucidus L., and Bursera simaruba (L.) 
Sarg. Flowering specimens have been collected from March to August, and fruiting specimens from October to December.

Common names.—Almácigo de costa (Combs, 1897), almácigo de paredón (Sauvalle, 1864).

Additional specimens examined. CUBA. HABANA: Campo Florido, Loma de La Coca, elev. 100 m, 12 Jul 1975, Bisse et al. 37281 (HAC, HAJB); Campo Florido, 27 Jan 1973, Gruchz 32375 (HAC); Campo Florido, Loma de Coca, 7 Dec 1914, León \& Hioram 14955 (HAC); Minas, cuabal al norte, 20 May 1916, León \& Roca 14958. ISLA DE PINOS (ISLA DE LA JUVENTUD): Sierra de Casas, 23 Nov 1920, Eckman 14951 (HAC); Hato Nuevo, 13 Aug 1919, Roig \& Crematos 1795 (HAC). MATANZAS: Cárdenas, Camarioca, Cantel, 19 Jun 1976 (immat fl), Berazaín \& González 31968 (HAJB); serpentines southeast from Camarioca, 29 Nov 1976, Köhler et al. 39579 (HAC). PINAR DEL RIO: Pan de Guajaibón, La Mulata, 16 may 1953, Acuña \& Alain 18576 (HAC); Falda norte del Pande Guajibón, 16 May 1953, Alain \& Acuña 14981 (HAC); La Pelada de la Cajálbana, La Palma, Aug 1954 (fr), Acuña et al. 19402, (HAC); Viñales, Cumbre de la Sierra del Jíbaro, Finca El Ancón, 20 May 1955, Alain 14954 (HAC); La Cajálbana, La Palma, Mar 1966, Veroslav 26014 (HAC); Pan de Azucar, near the top, 4 Dec 1925, Roig \& Sánchez 3846 (HAC). SANTIAGO DE CUBA: Segundo Frente, on the road of Saca la Lengua to Mícara, 25 Apr 1985, Alvarez et al. 56664 (HAJB); VILLA CLARA: Santa Clara. Savanna near Santa Clara, 29 Jun 1931, Alain 14951 (HAC); Lomas de Agabama near Agabama dam, 30 Oct 1986 (fr), Arias et al. 59993 (HAJB); Minas de Motembo, southwest from town, 26 Oct 1979, Bisse et al. 40893 (HAJB).

Bursera aromatica Proctor in Bull. Inst. Jamaica, Sci. Ser. 16: 16. 1967. Type. Jamaica: Trelawny, Ramgoat Cave área of the Cockpit Country, 1500 ft., 6 Apr 1963 (o fl), Proctor 21457 (holotype: IJ; isotypes: LL). 
Andromonoecious trees to $12 \mathrm{~m}$ tall. Trunk monopodial. Bark gray, close ; sap resinous, aromatic. Trichomes absent. Leaves $19-23 \mathrm{~cm}$ long, 3-5-foliolate; petiole 5.2-6 cm long, terete; lateral petiolules $1.4-2.2 \mathrm{~cm}$ long, terminal petiolule $2.2-3.1 \mathrm{~cm}$ long; lateral leaflets $7-10 \times 3-7 \mathrm{~cm}$, (broadly) ovate, terminal leaflet $8.5-10 \times 4.2-4.8 \mathrm{~cm}$, ovate to oblanceolate; apex bluntly acuminate; base of lateral leaflets symmetric, rounded to truncate (rarely subcordate); leaflets coriaceous, dull, drying dark brown; on both sides of lamina the midvein and secondary veins prominent, pale yellow when fresh. Inflorescence a simple or sometimes compound raceme, 3-11 cm long, 1.3-1.5 mm diam at base, longer than petiole of subtending leaves. Bracts subtending the flowers $0.3-0.5 \mathrm{~mm}$ long, lanceolate. Bisexual flowers 3-merous, calyx ca. $1 \mathrm{~mm}$ long, petals ca. 2 $\mathrm{mm}$ long, very broadly ovate, stamens 6 in two subequal series, ca. $1.5 \mathrm{~mm}$ long; stigma discoid, very obscurely 3-lobed. Staminate flowers 3-merous, 3-3.5 mm long at anthesis; calyx 1.8-2.2 x 1.2-1.4 $\mathrm{mm}$, taller than the disk, cupular, the lobes $1.2-1.4 \mathrm{~mm}$ long, deltate; petals greenish cream, 2.5-2.8 x 1.4-1.6 mm, ovate, with an inflexed apiculum $0.2 \mathrm{~mm}$ long; stamens 6 , in two equal series, $2.3-2.4 \mathrm{~mm}$ long with dorsifixed oblong anthers $1.1-1.2 \mathrm{~mm}$ long; disk $0.4-0.7 \mathrm{~mm}$ tall, 0.3-0.5 $\mathrm{mm}$ thick; pistillode very reduced, $0.4 \mathrm{~mm}$ long, ovoid, with three rudimentary styles; fruiting pedicel 4-7 mm long, green. Fruits 9-11 x $7 \mathrm{~mm}$, obliquely ellipsoid, apex acute, base rounded. Cotyledons and germination unknown.

Leaf architecture.-Major secondary framework simple brochidodromous with major secondary spacing regular and uniformly angled, major secondary attachment to the midvein decurrent; epimedial tertiary veins $<1$ per intercostal area, parallel to major secondaries, with length $<50 \%$ of subjacent secondaries and reticulating distally, intercostal tertiary vein fabric irregular reticulate, exterior tertiary course terminating at the margin (not looped), quaternary vein fabric freely ramifying, areolation poorly developed, freely ending veinlets (FEVs) dendritically $2+-$ branched and terminating in tracheoid idioblasts; marginal ultimate venation incompletely looped. 
Leaf anatomy._- Leaves isostomatic, palisade parenchyma ca. $100 \mu$ thick, spongy parenchyma tight, $150-200 \mu$ thick. Crystals hexagonal and rhomboid, scattered around the primary vein and abaxially along the lamina. Primary vein with one adaxial and three abaxial resin canals.

Distribution and ecology.-Bursera aromatica occurs in the parishes of Hanover, Trelawny and St. James in Jamaica, on wooded rocky dogtooth limestone hills, ranging in elevation from 440 $670 \mathrm{~m}$. Flowering specimens have been collected from January to July, and fruiting specimens from March to August.

Conservation status.-Populations of B. aromatica are restricted to their particular habitat on wooded hills, making it a vulnerable species (IUCN 2011).

Common name.-Siboney (Proctor 22597).

Additional specimens examined. JAMAICA. Hanover: Dolphin Head, 18²2’23”N, 789’20”W, 570 m, 13 Sep 2001, Parker 3751 (UWI); Summit of Bubby Hill, ca. 1 mile southwest of Hillsbrook, ca. 1450 ft., 31 May 1970, Proctor 31315 (IJ). Trelawny: along road from Burnt Hill to Ramgoat Cave, ca. 500 m, $18^{\circ} 25^{\prime} \mathrm{N}, 77^{\circ} 33^{\prime} \mathrm{W}, 20 \mathrm{Jul} 1997$ (fl), Acevedo et al. 9581 (UWI); Ramgoat Cave district, Cockpit country, 360 m, 7 Jun 2001 (fr), Campbell s.n. (IJ); Cockpit Country, 1-2 km north of Burnt Hill, 18 $19^{\prime} \mathrm{N}, 7^{\circ} 33^{\prime} \mathrm{W}, 600$ m, 14 Jan 1993, Daly \&Lewis 7613 (UWI); Burnt Hill between Albert Town and Troy, 560 m, 1 Feb 1908, Gentry \& Kapos 28316 (IJ); Ramgoat Cave area of theCockpit Country, $1500 \mathrm{ft}$., 6 Apr 1963 (ठ fl), Howard \& Proctor 14127 (fr); Tyre District, 2 miles north of Troy, ca. 1750 ft., 14 Mar 1955 (fl), Proctor 9932 (IJ, two sheets); Island View Hill, 1.5 miles north of Warsop, 2000-2200 ft., 26 Mar 1960, (hermaphrodite fls and young fruits), Proctor 20750 (IJ, UWI); Island View Hill, Wilson Valley district, ca. 1.5 miles north of Warsop, 2000-2200 ft., 26 Jun 1960 (fr), Proctor 21340 (IJ); Ramgoat Cave area, Cockpit Country, 13 Oct 1960, ca. 1500 ft., Proctor 21432 (IJ); Ramgoat Cave area of the Cockpit 
Country, ca. 1500 ft., 6 Apr 1963 (fl), Proctor 23457 (IJ); Miss Laura’s Hill, Wilson Valley district, ca. 1 mile north of Warsop, 2000-2200 ft., 30 Mar 1964 (fl), Proctor 24754 (IJ); Mango Tree Hill, along road between Burnt Hill and Spring Garden, ca. 1800 ft., 2 Apr 1978 (fl), Proctor 37754 (IJ); Island View Hill, Wilson Valley district, 1.5 miles north of Warsop, ca. 2200 ft., 23 Mar 1979 (fl), Proctor 38092 (IJ); Along road north of Burnt Hill, ca. 1700 ft., 23 Feb 1980 (fl), Proctor 38598 (IJ); Vicinity of Ramgoat Cave, Cockpit Country, ca. 1500 ft., 20 Apr 2000 (fr), Proctor 51688 (IJ); Island View Hill, north of Warsop, ca. 2000 ft., 6 Jul 1965, Webster 13672 (IJ). St. James: White Rock Hill, ca. 1 mile south of Sweet Water (Johnson District), 2000-2200ft., 27 Jan 1963 (hermaphrodite fl), Proctor 23189 (IJ); same locality, 2100 ft., 7 Aug 1962 (fr), Proctor 22597 (IJ).

Bursera brunea Urb. \& Ekman in Ark. Bot. 22A(8): 59. 1928. Spondias brunea Urb. Symb. Antill. 7(2): 266. 1912. Type: HAITI: Gonaïves, Morne La Pierre, 50 m, May 1901 (male fl), Buch 615 (Lectotype [designated here]: HUH; isotype: NY).

Tree to $7 \mathrm{~m}$ tall, dioecious. Bark gray, close; branchlets grayish-brown, with suborbicular lenticels. Leaves 8-11-(16) cm long, (3)5-7(9)-foliolate; petiole 2-4 cm long, terete; basal lateral leaflets with petiolules $0.5-0.7 \mathrm{~mm}$ long, distal lateral leaflets sessile, terminal petiolule $6-7 \mathrm{~mm}$ long; interjuga $1.7(2.5)-2.8 \mathrm{~cm}$ long, lateral leaflets $4-5 \times 1.6-1.9 \mathrm{~cm}$, assymetric, slightly oblique, oblong-elliptic to elliptic; terminal leaflet (3)4-6.5 x 2.1-2.5 cm, obovate; leaflet apex acuminate, acumen 6-7 mm long or sometimes the apex obtuse; base of lateral leaflets often asymmetric, acute; base of terminal leaflet symmetric, acute; leaflets chartaceous and drying olive green to dark brown; on abaxial surface the primary and secondary veins prominent, yellow brown, on adaxial surface the midvein prominent. Staminate nflorescences (pistillate ones unknown) axillary, thyrsoid, $10-13 \mathrm{~cm}$ long, $0.8-1 \mathrm{~mm}$ diam, sparsely branched;; peduncle $4.5-5 \mathrm{~cm}$ long purplish brown, bracts deciduous, 1-1.5 mm long linear-subulate. Staminate flowers 5(4)-merous, $1.2-1.6 \mathrm{~mm}$ long, pedicel $1.3-1.6 \mathrm{~mm}$ long, calyx $0.8 \mathrm{~mm}$, taller than the disk, shallowly cupular, the lobes $0.4 \mathrm{~mm}$ 
long, deltate, fleshy; petals $1.3-3 \times 0.6-0.7-1.5 \mathrm{~mm}$, ovate elliptic, spreading at anthesis, with an inconspicuous inflexed apiculum $0.2 \mathrm{~mm}$ long; stamens $8-10$, in two equal series 3-4.5 mm long with dorsifixed, elliptic anthers $2.5 \mathrm{~mm}$ long; disk $0.2 \mathrm{~mm}$ tall, $0.2 \mathrm{~mm}$ thick, annular, 4-5-sulcate, glabrous; pistillode greatly reduced, $0.2 \times 0.2 \mathrm{~mm}$, shorter than the disk, with 3 rudimentary styles. Fruits, cotyledons and germination unknown.

Leaf architecture.-Major secondary framework simple brochidodromous with major secondary spacing irregular and angle uniform; intercostal tertiary vein fabric irregular reticulate; exterior tertiary course looped; areolation well developed, FEVs highly branched with simple termination (tracheoid idioblasts absent).

Distribution and ecology.--Bursera brunea is known from the type locality in Gonaïves Island and one collection from Great Inagua (Bahamas) growing on calcareous soil. Herbarium collections indicate that the species flowers in May and June.

Bursera brunea has been mistakenly identified in Dominican Republic herbaria and elsewhere. All current collections at JBSD under the name B. brunea are B. nashii (which is treated here as a synonym of $B$. glauca). Therefore, citations of $B$. brunea in previously published reconstructed phylogenies (Weeks \& Simpson, 2004) should be referred to B. glauca (including B. nashii). As mentioned above, there are very few collections of this species and it is not known if there are surviving populations in Hispaniola or the Bahamas. B. brunea is easy to recognize by its brownish, predominantly $5-7$-foliolate leaves, with medially assymetric lateral leaflets and by its long thyrsoid (staminate) inflorescence. Sterile plants most closely resemble B. simaruba, but they can be easily distinguished by their bark (the former gray and close vs. red and peeling). 
Additional specimens examined. BAHAMAS. Acklin Island: 3 km north of Salina Point, 6 Jun 1976 (fr), Correll et al. 47245 (FTG). Great Inagua: northeast of Conch Shell Point, 24 Jun 1978 (male fl), Correll 49953 (FTG, NY).

Bursera frenningae Correll in J. Arnold Arbor. 60: 157. 1979. Type. Bahamas: Great Exuma, between Mt. Thompson and Farmer's Hill, 8 Jul 1978 (fr), D. S. Correll 49984 (holotype: A; isotypes: F, FTG, NY, US).

Spreading shrubs or rarely small trees to $4.5 \mathrm{~m}$ tall, dioecious. Bark reddish or reddish brown, often shed in papery sheets, twigs with reddish brown bark. Trichomes (when present on inflorescences and calyx) consisting of erect fine hairs to $0.3 \mathrm{~mm}$ long. Leaves $8-10 \mathrm{~cm}$ long, 35(7)-foliolate; petiole 2.5-3(4) cm long, slender, terete; lateral leaflets sessile or the petiolules $0.3-$ $0.5 \mathrm{~mm}$ long, terminal petiolule 5-6 mm long; interjuga $1.5-1.8 \mathrm{~cm}$ long, lateral leaflets $5.6-6 \mathrm{x}$ 1.9-2.2 cm, broadly oblong-elliptic to elliptic-oblanceolate, terminal leaflet $6.1-6.3 \times 2.1-2.3 \mathrm{~cm}$, oblanceolate or sometimes obovate; leaflet apex acute or sometimes obtuse, mucronate; base of lateral leaflets usually symmetric, acute to cuneate, base of terminal leaflet mostly decurrent; leaflets thick-coriaceous and drying olive green to light brown, the midvein drying a distinctive pale yellow, faintly glossy adaxially and dull abaxially; on abaxial surface the secondary veins inconspicuous; on adaxial surface the midvein and secondary veins prominent. Inflorescences axillary, racemose-paniculate; staminate inflorescences 5-8 cm long, 0.5-1 mm diam; infructescences (pistillate inflorescences unknown) 4-6 cm long, 1-1.5 $\mathrm{mm}$ diam, peduncles up to $3.5 \mathrm{~cm}$ long., pedicel ca. $2 \mathrm{~mm}$. Staminate flowers 5-merous, $2.5 \mathrm{~mm}$ long, calyx $0.6 \mathrm{x} 1.4 \mathrm{~mm}$, taller than the disk, shallowly cupular, the lobes $0.4 \mathrm{~mm}$ long, deltate, separated by a short flat sinus $0.3 \mathrm{~mm}$; petals $2.1-3.1 \times 0.7-1.3 \mathrm{~mm}$, elliptic, yellowish green, somewhat spreading at anthesis, with an inconspicuous inflexed apiculum $0.3 \mathrm{~mm}$ long; stamens 10 , in two equal series $1.6 \mathrm{~mm}$ long 
with dorsifixed anthers $1 \mathrm{~mm}$ long, disk $0.3 \mathrm{~mm}$ tall, $0.3 \mathrm{~mm}$ thick, annular, sulcate, glabrous; pistillode greatly reduced, conic, $0.4 \times 0.4 \mathrm{~mm}$, shorter than the disk, with 3 rudimentary styles. Pistillate flowers 3-merous, calyx 1-1.5 mm long, broadly elliptic, obtuse, somewhat spreading, 2 $\mathrm{mm}$ long, staminodes 6; ovary sessile, stigma 3-lobed. Fruiting pedicel $2.5-3.5 \mathrm{~mm}$ long, stout and rigid, clavate; fruits 7-8 x 5-7 mm, subglobose, oblique, reddish brown; pyrene 6-7 x 4-5 mm, subglobose, trigonous, beige. Pseudaril, cotyledons, and germination unknown.

Leaf architecture.-Major secondary framework simple brochidodromous with major secondary spacing irregular and angle uniform, major secondary attachment to the midvein decurrent; intercostal tertiary vein fabric admedially ramified, irregular reticulate and alternate percurrent; exterior tertiary course looped; areolation poorly developed, FEVs highly branched with simple termination.

Leaf anatomy.-Leaves isostomatic, palisade parenchyma ca. $30 \mu$, spongy parenchyma ca. 20-30u. Crystals hexagonal and rhomboid, scattered along the lamina, abundant around the primary vein. Primary vein with three resin canals, lumen ca. $100 \mu$ diameter.

Distribution and ecology.-Bursera frenningae is distributed in the Bahamas and the Caicos Islands on hard-packed sand near ocean, open coppices, and coastal rocky thickets. Herbarium collections indicate that the species flowers June to October and fruits throughout the year, especially June to November.

Bursera frenningae is difficult to distinguish from B. inaguensis at first sight since the leaves are strikingly similar. However, B. frenningae can be identified by its tree habit, red peeling bark, and short thick inflorescences ca. $8 \mathrm{~cm}$ long x $0.5-1.5 \mathrm{~cm}$ diam (vs. B. inaguensis with shrubby habit, gray close bark, and slender longer inflorescences ca. $9 \mathrm{~cm}$ long x $0.5-0.7 \mathrm{~cm}$ diam). 
Some collections of $B$. frenningae also have broader leaflets and obovate terminal leaflet, while that of $B$. inaguensis tends to be oblong to oblanceolate.

Additional specimens examined. BAHAMAS. Acklin Island: $3 \mathrm{~km}$ north of Salina Point, 6 Jun 1976 (fr), Correll et al. 47245 (FTG). Cat Island: near Stevenson, 21 Nov 1975 (fr), Correll 46150 (FTG, NY); north edge of Port Howe, 22 Nov 1975 (fr), Correll 46222 (FTG); 1.8 mi south of Dumfries Town, wet valley between ridges, 13 Jul 1983 (fl), Sauleda 8382 (FTG). Exuma: Georgetown, 22-28 Feb 1905 (st), Britton \& Millspaugh 3124 (NY); northwest of Moss Town, 10 Dec 1973 (fr), Correll 40892 (FTG); southeast of Farmers Hill, 11 Jan 1975 (fr), Correll 44097 (FTG, NY); southeast of Farmers Hill, 17 Dec 1976 (fr), Correll \& Correll 47984 (FTG); between Steventon and Farmers Hill, 22 Jun 1978 (bisexual fl) Correll 49927 (FTG, NY); north of Georgetown, road to the forest, 12 Jun 1970 (male fl), Gillis 9406 (FTG). Grand Cay: Great Guana Cay, 21-22 Feb 1905 (fr), Britton \& Millspaugh (NY). Inagua: 20 Oct 1904 (fr), Nash \& Taylor 1204 (NY); Little Inagua, 22 Oct 1904 (fl), Nash \& Taylor 1279 (NY). Long Island: hills north of Salt Pond, 16 Mar 1977 (fr), Correll 48187 (FTG, NY); Harbor Point, Clarence Town, 19 Jun 1974 (fl), Hill 2223. TURKS AND CAICOS: 12 Mar 1911 (st), Millspaugh \& Millspaugh 9296 (NY).

Bursera gibarensis M. C. Martínez, Daly, \& J. Pérez (in press, Brittonia). Type: CUBA. Holguín: Gibara, Los Cocos, 18 Aug 2009 (fl \& fr), M. C. Martínez-Habibe, P. González, J. Pérez-Camacho, P. Herrera \& M. Cañizares-Morera 2307 (holotype: NY; isotypes: HAC, RSA).

Suffrutices to $30 \mathrm{~cm}$ tall, densely branching. Trichomes consisting of simple erect white hairs to $0.05 \mathrm{~mm}$ long and capitate glands $<0.05 \mathrm{~mm}$ long. Leaves $2.1-3.2 \mathrm{~cm}$ long, trifoliolate (rarely 5 -foliolate); petiole $4-9 \mathrm{~mm} \times 0.7 \mathrm{~mm}$, petiole and rachis sparsely pubescent; all 
leaflets sessile, chartaceous, drying olive green, the laterals $11-20 \times 2.3-4.5 \mathrm{~mm}$, narrowly (oblong-)elliptic, medially slightly asymmetric, terminal leaflet $13-23 \times 2.6-4.8 \mathrm{~mm}$, narrowly (oblong-)elliptic or slightly oblanceolate, leaflet apex obtuse, abruptly and narrowly shortacuminate, the acumen to $1 \mathrm{~mm}$ long, base acute and basal width asymmetric on laterals; some scattered trichomes near base of leaflets; on abaxial surface the midvein broadly prominulous, secondary veins flat or rarely broadly prominulous, rest of venation not visible; on adaxial surface the midvein narrowly prominulous and sometimes sunk in a groove, rest of venation not visible. Inflorescences to $1.4 \mathrm{~cm}$ long x $0.5-0.9 \mathrm{~mm}$ diam at base, unbranched, the axes densely to sparsely pubescent; bracteoles $0.3-0.5 \mathrm{~mm}$ long, subulate; pedicel $1.2-1.3 \times 0.3-0.4 \mathrm{~mm}$. Staminate flowers 5-merous, $3.1-4 \mathrm{~mm}$ long at anthesis, calyx $0.85-0.9 \times 1.3-1.4 \mathrm{~mm}$ overall, broadly elliptic in profile, the lobes $0.4-0.5$ long, triangular; petals $2.5-3 \times 0.8-0.9 \mathrm{~mm}$, subulate to narrowly oblanceolate, suberect at anthesis, the margin involute, dorsally slightly carinate, the inflexed apiculum $0.15 \mathrm{~mm}$ long, surface glabrous; stamens $10,1.9-2.05 \mathrm{~mm}$ long, the anthers $1.2-1.25 \mathrm{~mm}$ long, lanceolate in dorsiventral view, elliptic in lateral view, in two equal series; disk annular, undulate, $0.15-0.2$ tall $\times 0.1 \mathrm{~mm}$ thick; pistillode in a narrowly concave receptacle, $0.35-0.5 \times 0.1 \mathrm{~mm}$ overall, basal part ovoid to broadly ellipsoid, surmounted by 3 suberect lobules $0.25 \mathrm{~mm}$ long. Pistillate flowers unknown. In fruit the pedicel (measured beyond most distal bracteole) $1-2 \times 0.4-0.6 \mathrm{~mm}$, slightly clavate, the fruit $6-7 \times \mathrm{ca} .4 \mathrm{~mm}$, obliquely ovoid, the apex and base acute, some scattered trichomes toward base; pseudaril unknown (fruit immature). Cotyledons and germination unknown.

Leaf architecture.--Secondary vein fabric simple brochidodromous, secondary vein angle acute and uniform, spacing irregular, intercostal tertiaries transversely ramified and transverse freely ramified, epimedial tertiaries mixed, quaternary veins freely ramified, areolation poorly developed, FEVs (freely ending veinlets) dendritically 2+-branched, terminating in tracheoid idioblasts, marginal ultimate venation spiked. 
Leaf anatomy.-Leaves amphistomatic, two layers of palisade parenchyma, the adaxial palisade $80-100 \mu$, the abaxial ca. $30 \mu$; spongy parenchyma less developed. Crystals hexagonal and rhomboid, scattered. Primary vein with four resin canals.

Distribution and ecology.-Bursera gibarensis is endemic to xeromorphic coastal scrub that grows in the cavities in karst (dogtooth limestone) substrates in Hoguin Province, Cuba.

The vegetation consists mostly of shrubs $1.5-2 \mathrm{~m}$ tall featuring Plumeria spp., Eugenia spp., and Oplonia tetrasticha (C. Wright ex Griseb.) Stearn with occasional taller trees such as Bursera simaruba (L.) Sarg., Colubrina elliptica (Sw.) Brizicky, and the palm Copernicia yarey Burret, and a number of lianas such as Omphalea trichotoma Müll.Arg., Stigmaphyllon sagraeanum A. Juss., Triopterys jamaicensis L., Angadenia berteroi Miers, and Mesechites roseus (A.DC.) Miers, and finally species of Tillandsia that may be epiphytic or lithophytic. The species is known to flower and fruit in August.

Additional specimens examined. CUBA. Holguin: Los Cocos, Gibara, 27 Apr 1993, Brull \& Verdecia 2618 (HMC); Rafael Freyre, entre Gibara y Playa Caletones, 22 Oct 1978 (fr), Álvarez et al. (HAJB 38472)(HAJB, 3 sheets); Gibara, Los Cocos, 8 Jul 2008 (fr), GonzálezP.(HAC 42557)(HAC, 2 sheets), near Gibara toward Caletones, 27 Mar 1990 (buds), Oviedo et al. (HAJB 68690)(HAJB); Los Cocos, Gibara, 7 Mar 1990 (fr), Verdecia \& Brull 2423 (HMC).

Bursera glauca Griseb. Cat. Plant. Cub. 66. 1866. Terebinthus glauca Britt., Bull. Torrey Bot. Club 35: 342.1908. Elaphrium glaucum Rose, N. Amer. Fl. 25:245.1911.Commiphora 
glauca (Griseb.) Moncada, Rev. Jard. Bot. Nac. Univ. Habana 10:5.1989. Type: Cuba: Oriente, Wright 2277 [Lectotype (designated here): K, 2 sheets; isotypes: GOET, HAC, MO].

Bursera nashii Urb. in Symb. Antill. 8(1): 329. 1920. Terebinthus nashii Britt., Bull. Torrey Bot. Club 35: 342. 1908. Type. HAITI: Gonaïves to La Hotte Rochée on road to Terre Neuve, Nash \& Taylor 1559.[Lectotype (designated here): NY, 2 sheets]

Dioecious shrubs or trees to $6 \mathrm{~m}$ tall. Leaves 3-6 $\mathrm{cm}$ long, 1-5-foliolate (rarely 7foliolate); petiole 3-4 $\mathrm{mm} \times 0.7 \mathrm{~mm}$ diam; all leaflets sessile, chartaceous, drying pale green, the laterals $3.8-4.2 \times 1-1.2 \mathrm{~cm}$, narrowly oblong-elliptic to oblong, symmetric, terminal leaflet $3.9-$ $4.3 \times 1.3-1.4 \mathrm{~cm}$, oblong-elliptic to slightly oblanceolate; leaflet apex obtuse, abruptly and narrowly short-acuminate, base symmetric, acute to rounded; on abaxial surface the midvein broadly prominulous, ca. $2 \mathrm{~mm}$ wide at base and narrowing towards the tip, pale yellow, secondary veins prominulous, rest of venation not visible; on adaxial surface the midvein narrowly prominulous and sometimes sunk in a groove, rest of venation not visible. Inflorescences to $2.6 \mathrm{~cm}$ long x $0.5-0.9 \mathrm{~mm}$ diam at base; bracteoles $0.5-0.8 \mathrm{~mm}$ long, subulate, deciduous; pedicel $1.3-$ $1.5 \times 0.3-0.4 \mathrm{~mm}$. Staminate flowers 5 -merous, $3-5 \mathrm{~mm}$ long at anthesis, calyx $0.8-1.1 \times 1.3-$ $1.6 \mathrm{~mm}$ overall, narrowly cupular, the lobes $0.5-0.8$ long, triangular; petals $3.3-3.8 \times 1.2-1.5$ $\mathrm{mm}$, oblanceolate and narrowed at the base, suberect at anthesis, the margin involute, dorsally slightly carinate, the inflexed apiculum $0.3 \mathrm{~mm}$ long; stamens 10 in two equal series, $1.6-1.9 \mathrm{~mm}$ long, the anthers $0.9-1.2 \mathrm{~mm}$ long, oblong in dorsiventral view, elliptic in lateral view; disk $0.3-$ $0.5 \mathrm{~mm}$ tall $\times 0.2 \mathrm{~mm}$ thick, undulate; pistillode in a narrowly concave receptacle, reduced to an ovoid mound of tissue $0.2 \mathrm{~mm}$ tall, surmounted by 3 suberect lobules $0.1 \mathrm{~mm}$ long. Pistillate flowers unknown. Fruiting pedicel (measured beyond most distal bracteole) $1.3-1.5 \times 0.4-0.6$ $\mathrm{mm}$; fruit $6-7 \mathrm{x}$ ca. $4 \mathrm{~mm}$, obliquely ovoid, the apex and base acute; pseudaril unknown (fruit immature). Cotyledons and germination unknown. 
Distribution and ecology.-Bursera glauca is endemic to serpentine soils in Cuba (Camaguey, Holguin, Guantanamo and Santiago de Cuba provinces), the Dominican Republic (Independencia), and Haiti (Artibonite and Nord-Ouest). The associated vegetation consists mostly of Acacia sp., Agave albescens Trel., Buxus heterophylla Urb., Calliandra sp., Coccothrinax sp., Croton micradenus Urb., Guaiacum sp., Guapira obtusata (Jacq.) Little, Jacquemontia sp., Melocactus sp., Turnera diffusa Willd.ex Schult.,Plumeria spp., Pictetia sp., Ritterocereus hystrix (Haw.) Backeb., Simarouba glauca DC., and Stigmaphyllon sagraeanum A.Juss. The species is known to flower and fruit April through October.

Leaf architecture.-Secondary vein fabric simple brochidodromous, secondary vein angle acute and uniform, spacing irregular, intercostal tertiaries admedially ramified and irregular reticulate, epimedial tertiaries absent, quaternary veins freely ramified, areolation poorly developed, FEVs (freely ending veinlets) dendritically 2+-branched, simple termination, marginal ultimate venation incompletely looped.

Leaf anatomy._Leaves amphistomatic, palisade parenchyma on the adaxial palisade tight, biseriate, each series $40-60 \mu$, abaxial palisade biseriate, each series $15-30 \mu$; spongy parenchyma less developed and scattered. Crystals hexagonal and rhomboid, scarse and scattered along the lamina. Primary vein with three adaxial and one abaxial resin canals.

Liogier (1983) treated B. nashii as a synonym of B. glauca in his Flora de La Española, but there are no plant specimens in Hispaniola correctly labeled with this name, furthermore most specimens of $B$. nashii have been incorrectly labeled as $B$. brunea, a mistake that seems not related to morphology but rather to repeated reference to wrongly identified plants .

Additional specimens examined. CUBA. Camagüey: sabanas del camino de Cubitas, 1 Ago 1950 (fr), Acuña \& Rodríguez16272 (HAC); Cayo Romano, camino de Versalles a El Molino, 
15 May 1976 (st), Areces et al. 34200 (HAC); Sola, Silla de Cayo Romano, 21 Feb 1981 (st), Alvarez et al. 43758 (HAJB); Cayo Romano, camino de El Molino a Sabanita del Burro, 17 May 1976 (st), Berazain et al. 31687 (HAJB); Punta Cayo La Moca, Cayo Romano, 16 Sep 1984 (st), Moncada 36696 (HAC). Guantánamo: Baracoa, Imias, flada norte de la Loma del Cuero, 300 m, 5 Feb 1976 (fr), Areces et al. 29666 (HAJB); Baracoa, al oeste de Cajobabo, Jun 1967 (imm fl), Bisse \& Rojas 2432 (HAJB); Baitiquirí, camino a la Mina del Yeso, 2 Apr 1972 (st), Bisse \& Berazaín 21794 (HAJB); Maisí, primera terraza, 50 m, 3 Jun 1982 (fl), Bisse et al. 47501 (HAJB); Imías, La Chivera, 20 May 1982 (st), Bisse et al. 48199 (HAJB); Guantanamo Bay, United States Naval Station, 17-30 Mar 1909 (st), Britton 14971 (HAC); Caimanera, Estación Naval, Jul 1920 (imm fl), Hioram 14973 (HAC); Baracoa, Mesa de Prada, Jauco, 17 Jul 1924 (st), León 8622 (HAC); Llano de Maisí, 19 Ago 1939 (st), León \& Victoria 14965 (HAC); Mesa del Chivo, Maisí, 25 Aug 1939 (imm fl), León \& Victoria 14982 (HAC); Imias, km 5, Jan 1956 (st), Morton 20184 (HAC); carretera de Yateritas, 16 Jun 2008 (fl), Martínez-Habibe et al. 2235 (HAJB, NY, RSA), MartínezHabibe et al. 2236 (HAJB, NY, RSA), 16 Jun 2008 (st), Martínez-Habibe et al. 2237 (HAJB, NY, RSA); San Antonio del Sur, carretera entre Tortuguilla e Imías, 1 km antes de la comunidad Los Naranjos, 16 Jun 2008 (fl), Martinez-Habibe et al. 2238 (HAJB, NY, RSA); Imías, west of Cajobabo along coastal road to Imías, 2003’43”N, 74³3’45”W, 50 m, 15 Feb 2000 (st), Zona 844 (HAJB); Holguin: Mayari, Sierra de Nipe, Mayari Abajo, 300-300 m, Jun 1967 (st), Bisse \& Rojas 3967 (HAJB); Sierra de Nipe, Mayari Abajo, cerca de Nicaro, Apr 1968 (st), Bisse \& Köhler 8347 (HAJB); Sierra de Nipe, mayari Abajo, charrascales de la Loma de Winch, 400-600 m, Apr 1968 (st), Bisse \& Köhler 8602 (HAJB); Sierra Cristal, loma Saca la Lengua, 600 m, Apr 1970 (st), Bisse 15925 (HAJB); sabana al pie este del Cerro del Fraile, 15 May 1947 (imm fl), León \& Dahlgren 14968 (HAC); Gibara, hacienda Pesquero, 23 Mar 1932 (st), León 14984 (HAC); Bahía de Manatí, Puerto Manatí, Morro Ciego, Jan 1937 (imm fl), León 14972 (HAC); Puyra, 100 m al N de Holguin, cruce de La Palma, 15 Jun 2008 (fl), Martínez-Habibe et al. 2224 (HAJB, NY, RSA); loma al este 
de la Bahía de Naranjo, entrada al zoológico, 15 Jun 2008 (fl), Martínez-Habibe et al. 2227 (HAJB, NY, RSA); 15 Jun 2008 (st), Martinez-Habibe et al. 2229 (HAJB, NY, RSA); 15 Jun 2008 (st), Martínez-Habibe et al. 2233 (HAJB, NY, RSA); carretera Holguín-Gibara, 1 km antes de Floro Pérez, 15 Jun 2008 (imm fr), Martínez-Habibe et al. 2225 (HAJB, NY, RSA); entrada a Rafael Freyre, 15 Jun 2008 (st), Martínez-Habibe et al. 2228 (HAJB, NY, RSA); Rafael Freyre, Loma de Los Mineros, km 37 carretera a Guardalavaca, 29 Mar 1990 (st), Oviedo et al. 68732 (HAJB); Santiago de Cuba: camino del Morro, 26 Dec 1953 (st), Alaín 14976 (HAC); Guamá, 3 km oeste del Macho, 29 May 1988 (fl), Alvarez et al. 65572 (HAJB), 29 May 1988 (fl), Alvarez et al. 65578 (HAJB), 29 May 1988 (fl), Alvarez et al. 65584 (HAJB), 29 May 1988 (imm fr), Alvarez et al. 65588 (HAJB); Sierra Maestra, Pilon, Loma del Avión, 23 May 1971 (st), Bisse \& Lippold 19293 (HAJB); Santiago de Cuba, carretera de Ciudamar, Jun 1946 (imm fl), Clemente 14960 (HAC); entre Cuidamar y Cinco Reales, Feb 1944 (fr), Clemente 14959 (HAC); Renté, Bahía de Santiago, Oct 1944 (st), Clemente 14963 (HAC), 4 Aug 1935 (imm fl), León 14962 (HAC); Santiago de Cuba, alrededores del aeropuerto, 5 Jan 1954 (fr), López 14970 (HAC); aeropuerto Santiago de Cuba, 9-10 Apr 1954 (fl), López 1189 (HAC); Playa Berraco, costa sur, 27 Jun 1954 (imm fl), López 1519 (HAC); Santiago de Cuba, cerca del Yunque de Daiquirí, 2 May 1989 (imm fl), Gutiérrez et al. 67929 (HAJB); 3 km north of El Morro, 12 Aug 1951 (st), Webster 4060 (NY). DOMINICAN REPUBLIC: Independencia: aprox. 2 km norte de Puerto Escondido en la carretera a Duvergé, $18^{\circ} 19^{`} \mathrm{~N}, 71^{\circ} 48 \mathrm{~W}, 380$ m, 28 Ago 1987, Zanoni \& Pimentel 40400 (JBSD, NY). HAITI: Artibonite: $16.5 \mathrm{~km}$ al oeste de Gonaïves en la carretera costera a Anse-Rouge, $19^{\circ} 28 \mathrm{~N}, 72^{\circ} 46^{\prime} \mathrm{W}, 10 \mathrm{~m}, 9$ Jun 1985 (fl\&fr), Zanoni et al. 35007 (JBSD).Nord-Ouest: 9 km west Baie de Henne en el camino a Bombardópolis, $19^{\circ} 41^{\prime} \mathrm{N}, 73^{\circ} 15^{\prime} \mathrm{W}, 50-70 \mathrm{~m}, 22$ Oct 1983 (fr), Zanoni et al. 27704 (JBSD, NY) $13.1 \mathrm{~km}$ al este de Móle St. Nicolas en la carretera costera a Jean-

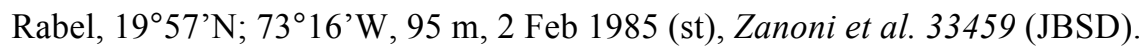


Bursera gracilipes Urb. \& Ekman in Ark. Bot. 22(8): 58. 1928. Type: DOMINICAN

REPUBLIC. Barahona, Couève-en-haut, path to Trujín, 22 Sep 1926 (fl), Ekman 7024 (Holotype: $\mathrm{S}$; isotypes: $\mathrm{G}, \mathrm{K}, \mathrm{US})$.

Shrubs or small trees to $6 \mathrm{~m}$ tall and $30 \mathrm{~cm}$ diam. Leaves $2-3 \mathrm{~cm}$ long, (1)3-5-foliolate; petiole $5-11 \mathrm{~mm} \times 0.5 \mathrm{~mm}$ diam, reddish at the base; lateral petiolules $0.5 \mathrm{~mm}$ long, reddish at the base, terminal petiolule 1-3 mm long, lateral leaflets $17-22 \times 6-9 \mathrm{~mm}$, oblong-elliptic, symmetric, terminal leaflet 13-23 x 2.6-4.8 mm, narrowly (oblong-)elliptic or slightly oblanceolate, leaflet apex acuminate, the acumen to $3.5 \mathrm{~mm}$ long, base acute or slightly obtuse; all leaflets membranaceous, glossy green, drying greenish-brown adaxially and pale green abaxially, on abaxial surface the midvein and secondary veins prominulous, on adaxial surface the midvein and secondary venation narrowly prominulous. Inflorescences axillary, racemose, dimorphic; staminate inflorescence to $2.8 \mathrm{~cm}$ long x $0.3 \mathrm{~mm}$ diam at base, producing $+/-10$ flowers; bracteoles $0.3 \mathrm{~mm}$ long, lanceolate-elliptic; pedicel 1.1-1.8 x $0.3-0.4 \mathrm{~mm}$; pistillate inflorescences to $1.8 \mathrm{~cm}$ long $\mathrm{x}$ $0.4 \mathrm{~cm}$ diam at base, 1-3-flowered; bracteoles not seen; pedicel $2.4-3.3 \times 0.3 \mathrm{~mm}$. Staminate flowers 4-merous, $2.7-3 \mathrm{~mm}$ long at anthesis, calyx $0.6-0.9 \times 1.3-1.6 \mathrm{~mm}$ overall, shallowly cupular, the lobes $0.6-0.7$ long, triangular; petals $1.7-1.9 \times 1-1.1 \mathrm{~mm}$, oblanceolate, reflexed at anthesis, the inflexed apiculum $0.3 \mathrm{~mm}$ long; stamens $8,1.3-1.5 \mathrm{~mm}$ long, the anthers $0.8-1.1$ $\mathrm{mm}$ long, oblong, apex subtruncate; disk $0.3 \mathrm{~mm}$ tall $\mathrm{x} 0.2 \mathrm{~mm}$ thick undulate; pistillode ovateoblong. Pistillate flowers 3-merous, $2.4-2.7 \mathrm{~mm}$ long at anthesis, calyx $1.6-1.8 \times 0.6-0.7 \mathrm{~mm}$, cupular, as tall as disk, the lobes $0.6 \mathrm{~mm}$ long, rounded; petals $1.8 \times 1 \mathrm{~mm}$, obovate, narrowed at base, reflexed at anthesis, pale yellow; staminodes $6,1.2-1.5 \mathrm{~mm}$ long, anthers $0.5 \mathrm{~mm}$ long, deltate, base sagittate in dorsiventral view, filaments triangular; disk $0.3 \mathrm{~mm}$ x $0.2 \mathrm{~mm}$ thick; ovary 1.6-1.8 x 0.9-1.1 mm, ovoid, substipitate, (stipe ca. $0.2 \mathrm{~mm}$ tall), style inconspicuous, stigma capitate, $0.4 \times 0.6 \mathrm{~mm}$. Fruiting pedicel $0.8-1 \times 0.2 \mathrm{~cm}$, clavate; fruits $1-1.2 \times 0.7 \mathrm{~cm}$, ovoid or 
ellipsoid, slightly oblique, green but turning reddish, pyrene ca. 0.7 x $0.5 \mathrm{~cm}$, trigonous. Cotyledons and germination unknown.

Leaf architecture.-Secondary vein fabric simple brochidodromous, secondary vein angle acute and uniform, spacing regular, intersecondary veins ca. 1 per intercostal area, parallel to major secondaries, reticulating distally; intercostal tertiaries irregularl- reticulate, epimedial tertiaries reticulating, quaternary veins freely ramified, areolation poorly developed, FEVs dendritically $2+-$ branched, terminating in tracheoid idioblasts, marginal ultimate venation incompletely looped.

Leaf anatomy.-Leaves isostomatic, palisade parenchyma uniseriate, $70-80 \mu$, spongy

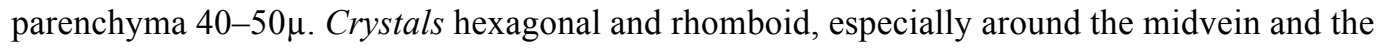
margin. Primary vein with three adaxial and two abaxial resin canals.

Distribution and ecology.- Known only from Pedernales and Barahona in the Dominican Republic, in dry forest on calcareous soil, this species is associated with Catalpa macrocarpa Ekman, Eugenia pitrensis Urb., Mimosa diplotricha C.Wright, Opuntia sp. and Senna atomaria (L.) Irwin \& Barneby. Flowering specimens have been collected in June to September and fruiting specimens in September.

Conservation status. - B. gracilipes has not been assessed by the IUCN, but its restricted distribution in a single dry forest and very few collections suggests that it should be considered at least a vulnerable species.

B. gracilipes is the only predominantly 3 -foliolate species of Bursera in the region. It was proposed as a hybrid species between B. simaruba and B. spinescens by Weeks and Simpson (2004) based on molecular evidence. However, a close examination to Week's voucher specimens used for the DNA analysis revealed that her putative collection of B. gracilipes corresponds to a possible hybrid specimen, but not to B. gracilipes. Published in 1928 by Urban and Ekman from a male 
plant, few recent specimens have provided female flowers -- something unusual in Bursera collections. It is known from only one small population, although it is possible that more intensive expeditions will find additional populations in similar habitats in Haiti. Phylogenetic reconstruction of the GAB species rendered B. gracilipes sister to B. brunea.

Additional specimens examined. DOMINICAN REPUBLIC. Pedernales: Oviedo, km 18-19, próximo al km 19 a la orilla del camino, mano derecha, subiendo desde Pedernales a

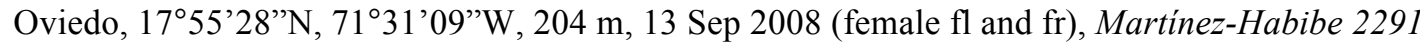

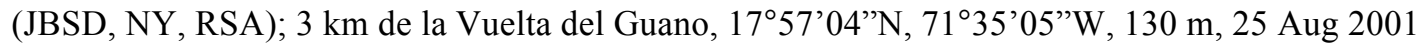
(fl), Veloz \& Jimenez 2679 (JBSD); Bahía de Las Aguilas, $200 \mathrm{~m}$ antes de descender a la playa, 16 m, 30 Jun 2006, Veloz et al. 4053 (JBSD).

Bursera hollickii (Britt.) Fawc. \& Rendle in Fl. Jamaica 4: 207. 1920. Terebinthus hollickii Britt., Bull. Torrey Bot. Club 35: 341. 1908. Elaphrium hollickii Rose, N. Amer. Fl. 25: 246. 1911. Type. Jamaica: Fort Henderson, Kingston Harbor, 2 Mar 1908(fr), Britton \& Hollick 1816 (NY).

Tree up to $6 \mathrm{~m}$ tall, $10 \mathrm{~cm}$ diam. Trunk monopodial, $25 \mathrm{~cm}$ diam. Bark reddish-gray outside, red inside, close, not peeling in thin papery sheets; young twigs stout. Leaves $8-12 \mathrm{~cm}$ long, 3-7-foliolate; petiole $2.5-2.7 \mathrm{~cm}$ long, terete; lateral petiolules $4-6 \mathrm{~mm}$ long; terminal petiolule 6-7 mm long; lateral leaflets 3.5-4.1 cm long, ovate; terminal leaflet 3.4-6.4 cm long, ovate to oblong; leaflet apex short-acuminate; base of leaflets symmetric or sometimes asymmetric, rounded; margin flat; leaflets coriaceous, dull, drying brown abaxially and light brown adaxially ; on abaxial surface the midvein conspicuous, lamina green, secondary veins inconspicuous; on adaxial surface the midvein and secondary veins inconspicuous.Flowers unknown. Infructescences a raceme simple or slightly compound, short, $4-7 \times 0.2-0.3 \mathrm{~cm}$ long, axis pubescent $0.1 \mathrm{~mm}$. Fruits 8-10 x $7 \mathrm{~mm}$, green, obovoid, pseudaril red-orange, bluntly triangular, pedicel stout, clavate, 3.1-4 mm long; pyrene 6 x $5 \mathrm{~mm}$, sharply trigonous, beige. Cotyledons and germination unknown. 
Leaf architecture.-Major secondary framework simple brochidodromous with major secondary spacing irregular and angle uniform, major secondary attachment to the midvein decurrent; epimedial tertiary veins $<1$ per intercostal area, parallel to major secondaries, with length $<50 \%$ of subjacent secondaries and reticulating distally, intercostal tertiary vein fabric irregular reticulate, exterior tertiary course looped, quaternary vein fabric freely ramifying, areolation moderately developed, FEVs dendritically 2+-branched and terminating in tracheoid idioblasts; marginal ultimate venation looped.

Leaf anatomy._- Leaves isostomatic, palisade parenchyma ca. $80 \mu$ thick, spongy parenchyma tight, $80-160 \mu$ thick. Crystals hexagonal, scares, scattered around the primary vein and abaxially along the lamina. Primary vein with one adaxial and five abaxial resin canals.

Distribution and ecology.-Bursera hollickii occurs in the parishes of Clarendon, St. Andrew and St. Catherine, on dry thickets of limestone woodland, at $300 \mathrm{~m}$. There are not specimens with flowers and only one fruiting specimen is known from a collection in January.

Conservation status. - This very rare and poorly known species is confined to a restricted habitat under severe human pressure, and it is rightly considered endangered (IUCN 2011).

Common name.- Red birch (Daly 7590).

Bursera hollickii resembles $B$. simaruba because of the size and number of leaflets, but the bark is close and its lealets are coriaceous (vs. peeling bark and chartaceous leaflets). . This species needs urgent attention since its last remaining known populations are on Long Mountain, in a suburban area near Kingston surrounded by housing development projects, so it should be considered critically endangered (Oberli, pers. comm.). Additionally, B. hollickii is the endemic Jamaican Bursera species with fewest collections and no flowering material has been ever collected. 
Additional specimens examined. JAMAICA. Clarendon: Braziletto Mountains, -- 1991, Morgan n.n. (UWI);St. Andrew: Long mountain, NE slope, Berverly Hills, trail beyond water tank at end of Montclair Drive, 300 m, 1800’00’N, 7645’00”W, 11 Jan 1993 (fr), Daly 7590 (NY, UWI) Long Mountain, May 2003, Yee \& Yunor n.n. (UWI). St. Catherine:path to Rodney’s Lookout, Port Henderson Hill, 400 ft., 2 Feb 1966, Adams 12800 (UWI); Fort Henderson, 3 Feb 1908, Harris 10149 (NY, UWI);Great Goat Island, 1 Mar 1944, Lewis n.n.(IJ).

Bursera inaguensis Britt. in Bull. N.Y. Bot. Gard. 3(11): 1905.Terebinthus inaguensis Britt.,Bull. Torrey Bot. Club 35: 342. 1908. Elaphrium inaguense (Britt.) Rose, N. Amer. Fl. 25: 245. 1911. Commiphora inaguense (Britt.) Moncada, Rev. Jard. Bot. Nac. Univ. Habana 10: 5. 1989. Type. Bahamas: Little Inagua, Moujean Harbor, Oct 1904, Nash \& Taylor 1190 (NY).

Shrub or small tree, up to $3.3 \mathrm{~m}$ tall. Trunk monopodial, often swollen.Bark grayish, tight. Trichomes (only on inflorescences and calyx when present) consisting of erect fine hairs to $0.3 \mathrm{~mm}$ long. Leaves 8-10 cm long, 3-7-foliolate; petiole slender, 2-5 cm long, terete; lateral leaflets sessile or the petiolules $0.3-0.5 \mathrm{~mm}$ long; terminal petiolule $3.5-4.5(8) \mathrm{mm}$ long; distance between pairs of lateral leaflets $2 \mathrm{~cm}$ long lateral leaflets 4.1-4.7(6) x 0.9-1.3 cm long, oblong to oblanceolate; terminal leaflet 4.6-5.7(6) x 1.4-1.9 cm long, lanceolate-elliptic to oblanceolate or sometimes obovate; leaflet apex acute or sometimes obtuse, mucronate; base of lateral leaflets usually symmetric, acute to cuneate; base of terminal leaflet mostly decurrent; margin flat; leaflets coriaceous and drying olive green to light brown, faintly glossy adaxially and dull abaxially; on abaxial surface the secondary veins inconspicuous; on adaxial surface the midvein and secondary veins prominent. Inflorescences dimorphic, paniculate, axillary; staminate inflorescences 5-6 cm long, $0.5 \mathrm{~mm}$ diam; pistillate infructescences (pistillate inflorescences unknown) 9-10.5 cm long, $0.7 \mathrm{~mm}$ diam, peduncles $4.5-6.5(8) \mathrm{cm}$ long, glabrous or with scattered hairs. Pistillate flowers unknown. Staminate flowers $3 \mathrm{~mm}$ long; perianth 5-merous; calyx 1.5 x $2.4 \mathrm{~mm}$, taller than the disk, shallowly cupular, the lobes $0.6 \times 0.8 \mathrm{~mm}$, deltate, separated by a short flat sinus $0.2-0.3 \mathrm{~mm}$; 
petals 5.9-6.1 x 2.7-2.9 mm, slightly oblanceolate, cucullate, fleshy, with an inconspicuous inflexed apiculum $0.5 \mathrm{~mm}$ long; stamens 10, $2.4 \mathrm{~mm}$ long with dorsifixed anthers $1.6-1.8 \mathrm{~mm}$ long, in two equal series, slightly ovate in dorsiventral view, oblong in lateral view, filaments $1.6 \mathrm{~mm}$ long, triangular, fleshy; disk $0.5 \mathrm{~mm}$ tall, $0.4 \mathrm{~mm}$ thick, annular, 5 -sulcate, glabrous; pistillode greatly reduced, $0.4 \times 0.4 \mathrm{~mm}$ shorter than the disk, with 3 rudimentary styles. Fruiting pedicel 2-6 $\mathrm{mm}$ long, clavate; fruits $6-7$ × $5 \mathrm{~mm}$, globose; pyrene (4.5)6-7 x 3-4 mm, subglobose, trigonous with flat sides, beige. Cotyledons and germination unknown.

Leaf architecture.-Major secondary framework simple brochidodromous with major secondary spacing irregular and angle uniform, major secondary attachment to the midvein decurrent; intercostal tertiary vein fabric admedially ramified and alternate percurrent; exterior tertiary course terminating at the margin (not looped); areolation with moderate development, FEVs 2+-branch with simple termination.

Leaf anatomy._Leaves isostomatic, palisade parenchyma ca. $100 \mu$, spongy parenchyma well developed and tight, ca. $120 \mu$. Crystals hexagonal and rhomboid, especially around the primary vein. Primary vein with three resin canals.

Distribution and ecology.--Bursera inaguensis occurs in the Bahamas (Great Inagua Island) and central Cuba on evergreen forest formations and rocky scrublands. Associated flora includes Stigmaphyllom sagraeanum A. Juss., Pictetia sp., Guapira obtusata (Jacq.) Little, Guapira discolor (Spreng.) Little, Buxus heterophylla Urb., Pseudocarpidio sp., Ateleia gumifera (Bertero ex DC.) D. Dietr., Furcraea hexapetala (Jacq.) Urb., Turnera difusa Willd. ex Schult. and Bursera simaruba (L.) Sarg. Flowering specimens have been collected from June to August, and fruiting specimens from August to September. 
Additional specimens examined. BAHAMAS. Great Inagua: north of Matthewtown, 2 Mar 1974 (fr), Correll 41726 (FTG); in coppice along road between Conch Shell Piont and Lantern Head, 3 Aug 1975 (fl), Correll 45896 (FTG); in yard in Matthewtown, 9 Aug 1975 (fl), Correll 45981 (FTG); in coppice in northwest sector of island, Aug 12-16, 1975, Correll \&Haxby 45990 (FTG); on high ledges above saline lake in southwest sector of island, Aug 12-16 1975 (fr), Correll \& Haxby 45997 (FTG); in coppice on east edge of Matthewtown, 21 Jul 1976 (fl), Correll 47445 (FTG); open coppice about Horse Pond, just north of Matthewtown, 23 Jun 1978 (fl), Correll 49945-A (FTG); Wreckley Hill, 2057’31.4”N, 7340’24.7” W, 8 Jul 2004 (fl), Freid 04-172 (FTG); Little Inagua, Moujean Harbor, Oct 1904, Nash \& Taylor 1190 (F); 0.5 miles northeast of Matthewtown, 13 Feb 1973, (fr), Proctor \& Gillis 33241 (FTG). CUBA. Habana: autopista Sancti Spiritus-Habana, km 80, desvío hacia loma de Agabama, 22¹6’16”N, 7951’01’W, 190 m, 7 Sep 2008, Martínez-Habibe et al., 2259 (NY, RSA); autopista Sancti Spiritus-Habana, km 80, desvío hacia loma de Agabama, 22 $16^{\prime} 17^{\prime}$ N, 7951'01'W, 220 m, 7 Sep 2008, Martínez-Habibe et al., 2263 (NY, RSA).Trinidad: Farallón del Río Guaurabo. Finca Los Leones, 13 Jun 2008 (fr), Martínez-Habibe et al. 2222 (NY, RSA).

Bursera lunanii (Spreng.) C.D. Adams \& Dandy ex Proctor, J. Arnold Arbor. 63: 254. 1982. Elaphrium jamaicense Rose, N. Amer. F1. 25: 244. 1911. Terebinthus simplicifolia Britt. Bull. Torrey Bot. Club 35: 342. 1908. Bursera simplicifolia DC. Prodr. 2: 78. 1825. Type: Harris 11946 (Lectotype: IJ [designated here]).

Amyris lunanii Spreng, Syst. Veg. (ed. 16) 2: 217. 1825. Type: presumably lost (see discussion below).

Tree, 3-15 m tall. Trunk monopodial, distal branches upcurving and spreading. Bark grayish to dark brown, rough, sometimes shed in plates (not papery sheets). Leaves simple, $6-8 \mathrm{~cm}$ long, petiole 4-5 cm long, lamina elliptic to obovate, medially symmetric, somewhat coriaceous, 
glossy, green, apex rounded or slightly acuminate to subemarginate, base acute and somewhat decurrent, drying light brown adaxially and light brown abaxially; on both surfaces the primary and secondary veins prominent. Inflorescences axillary, paniculate, few-flowered; staminate inflorescences $4.5-7 \mathrm{~cm}$ long, $1.2-1.6 \mathrm{~mm}$ diam, longer than the subtending leaves, primary axis sustaining the flowers on short pedicels $1-1.5 \mathrm{~mm}$ long, agglomerated in verticilles, bracteoles subtending the flower $0.8-1 \mathrm{~mm}$ long, elliptic-lanceolate; infructescences (pistillate inflorescences unknown) (2)3-6 cm long, 2-3 mm diam, peduncles $2.5-4 \mathrm{~mm}$ long. Staminate flowers $2-2.5 \mathrm{~mm}$ long; perianth 4-5-merous; calyx 2.2-2.6 x $1.4 \mathrm{~mm}$, taller than the disk, open and shallowly cupular, pale green, the lobes $0.6 \times 1.4 \mathrm{~mm}$, deltate, apex acute; petals $2.7-2.9 \times 1.5-1.7 \mathrm{~mm}$, slightly oblanceolate, spreading open and flat, slightly involute, creamy white, fleshy, with an inconspicuous inflexed apiculum $0.3 \mathrm{~mm}$ long; stamens diplostemonousin two equal series, $1.6 \mathrm{~mm}$ long with dorsifixed anthers $0.9-1.1 \mathrm{~mm}$ long, oblong elliptic in dorsiventral and lateral views, filaments triangular, fleshy; disk $0.3 \mathrm{~mm}$ tall, $0.6 \mathrm{~mm}$ thick, 4-5-sulcate; pistillode greatly reduced, $0.3 \times 0.2 \mathrm{~mm}$, with 3 rudimentary styles. Fruiting pedicel $2.5-4 \mathrm{~mm}$ long, slightly clavate; fruits 8$9 \times 6 \mathrm{~mm}$, subglobose to elliptic; pyrene 7 x 4-5 mm, subglobose, trigonous with flat sides, beige. Cotyledons and germination unknown.

Leaf architecture.-Major secondary framework simple brochidodromous with major secondary spacing irregular and angle uniform, major secondary attachment to the midvein decurrent; intercostal tertiary vein fabric transversely ramified(opposed tertiary veins from adjacent major secondaries ramify and join at a higher vein order); exterior tertiary course looped; areolation moderately developed, FEVs 2+-branched, terminating in tracheoid idioblasts; marginal ultimate venation looped.

Leaf anatomy.-Leaves isostomatic, palisade parenchyma 60-80 $\mu$, lax, spongy parenchyma well-developed and lax, ca. $100 \mu$. Crystals hexagonal and rhomboid, scattered around the primary 
vein and very abundant along the lamina within the spongy parenchyma. Primary vein with one resin canal adaxially and four abaxially.

Distribution and ecology.-Bursera lunanii is a Jamaican endemic that occurs in the parishes of Clarendon, Kingston, St. Ann, St. Andrew, St. Catherine, St. Elizabeth and St. Thomas in dry woodlands and low thorn-scrub. Some associated flora includes Cassia emarginata L., Capparis ferruginea $\mathrm{L}$. and Bauhinia divaricata Lam.

Conservation status.-This species was considered rare in 1997 but was upgraded to lower risk/near threatened in 1998 because it was found to be locally common in all the parishes in southern Jamaica. Although it is the best-collected Jamaican species, there are no collections with female or bisexual flowers.

Common name.-Bastard birch-gum (Lewis 76), black birch (Daly 7591).

Bursera lunanii is easy to distinguish from its Jamaican congeners by its simple, oblongelliptic leaves and non-peeling bark. Cuban B. shaferi is further distinguished from B. lunanii by having simple leaves, but in the former they are narrowly lanceolate (vs. elliptic to obovate) and its red bark is shed in thin papery flakes.

Urban (1908) placed Amyris lunanii in synonymy under Bursera simplicifolia, unaware that Sprengel's name antedated that of de Candolle's. Rose placed Terebinthus simplicifolia in synonymy under Elaphrium jamaicense because there was already a Mexican E. simplicifolium. D.C. Adams (1972) proposed the new combination in Bursera without formally validating it, then Proctor (1982) published the combination. Sprengel's type specimen for Amyris lunanii is presumably lost. His herbarium was dismembered and sold in fragments to different individuals and institutions (Stafleu and Cowan, 1977-1988). 
Additional specimens examined. JAMAICA. Clarendon: Portland Ridge, Jul 1955 (fr), Asprey 2170 (UWI); Portland Ridge, 500-1000 ft., Jul 1955 (fl), Asprey 2482 (UWI); east end of Portland Ridge, 11 Jul 1950(st), Howard s.n. (IJ); Portland Ridge, 400 ft., Aug 1943, Lewis 76 (IJ); Portland Point, 1 Mar 1949 (st), Lewis s.n.(IJ); Harris savanna, near the high-power lines,

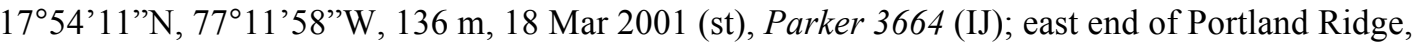
10-50 ft., 24 Feb 1971 (st), Proctor 31647 (IJ). Kingston: scrub-covered limestone hillsides onroad to Wareika, 300-700 ft., 5 Jul 1965(st), Webster 13659 (IJ). St. Andrew: Long Mountain, 800 ft., 5 Feb 1960 (fl), Adams 6201 (UWI); Long Mountain, 24 Jun 2005 (st), Biggs s.n. (UWI); Long Mountain, northeast slope, Beverly Hills, trail beyond water tank at end of Montclair Drive, $18^{\circ} 00^{\prime} \mathrm{N}, 76^{\circ} 45^{\prime} \mathrm{W}, 300$ m, 11 Jan 1993 (immat. fr), Daly 7591 (UWI); Long Mountain, 25 Feb 1962 (fl), Skelding 10703 (UWI); Long Mountain, Beverly Hills, 18 Mar 2003 (st), Yee \& Junior s.n. (UWI). St. Ann: Discovery Bay, 30 ft., 10 Sep 1960 (fl), Adams 8056 (UWI); along Queen's Highway, 1.5 miles from Dry Harbour, 21 Jul 1969 (fl), Powell 972 (IJ); along Queen’s Highway 2 miles east of Rio Bueno, 25-50 ft., 14 Sep 1957 (fl), Proctor 16617 (IJ). St. Catherine: Hellshire Hills, central portion, due south of Spanish Town on Windsor Rd., then 3 hrs hike from end of side road, 1752’N, 7658'W, ca. 140-200 m, 12 Jan 1993 (fl), Daly 7594 (UWI); Great Goat Island, 18 Jul 1906 (fl), Harris 9326 (UWI); Long Mountain, south side, 21 Jun 1907 (fl), Harris 9591 (UWI); Great Goat Island, Old Harbour Bay, 4 Mar 1908 (fl), Harris 10166 (UWI); Long Mountain, 100 ft., 10 Apr 1915(st), Harris 11946 (UWI); Lazaretto, above Port Henderson, 100-250 ft., 27 Mar 1955 (fr), Proctor 9972 (IJ); Pigeon Island, 4 Mar 1956 (fl), Proctor 11660 (IJ); Old House Point, Q.3, ca. 10 ft., 5 Aug 1970 (st), Tulloch 101 (IJ, UWI); Deanery, Q.5, on undulating limestone, 75 ft., 20 Aug 1970 (st), Tulloch 201 (IJ); inland from Wreck Bay, Hellshire Hills, ca. 150 ft., 4 Aug 1978 (st), Proctor 37929 (IJ); vicinity of Hellshire Point, ca. 50 ft., 15 Nov 1979 (st), Proctor 38380 (IJ); Port Henderson Hill, above Lazaretto, Jan 1955 (fl), Robertson 2193 (UWI); Port Henderson Hill near Green Bay Road, 27 Feb 1962 (fl), Skelding 9260 (UWI); Hellshire Hills, 
Manatee Bay, Q.1, 20-40 ft., 20 Jul 1970 (st), Tulloch 23 (UWI); Hellshire Hills, Deanery, Q.5, ca. 75 ft., 20 Aug 1970 (st), Tulloch 201 (UWI); Port Henderson Hill, 50-250ft., 2 Jul 1954 (st) Webster \& Wilson 4931 (IJ). St. Elizabeth: Great Pedro Bluff, 50-100 ft., 11 May 1956 (fl), Proctor 15374 (IJ); near milepost 21 along road between Alligator Pond and Bull Savannah, 500600 ft., 28 Sep 1969 (st), Proctor 31057 (IJ). St. Thomas: Four Mile Wood, between Bull Bay and Grants Pen, ca. 500 ft., 28 Sep 1958 (st), Proctor 18270 (IJ); lower north slope of Sugar Loaf Hill, near Bull Bay, 100-200 ft., 11 Aug 1963 (fl), Proctor 23929 (IJ).

Bursera shaferi Urb. Repert. Spec. Nov. Regni Veg. 22: 363. 1926. Elaphrium shaferi Britt., Mem. Torr. Bot. Club 16: 71. 1920. Type: Cuba: Pinar del Río, La Guira, north of Sumidero, 17 Aug 1912 (fr), Shafer 13751 (holotype: NY [designated here]; isotype: HAC).

Dioecious trees, 4-6 m tall.Trunk monopodial. Bark red, peeling in thin papery sheets. Branches dark brown, with sparse rounded lenticels andshort shoots. Trichomes absent. Leaves (4)7-9 x (1)2-2.8 cm, 1-(2-3)-foliolate petiole (1)1.3-2.3 cm long, terete; leaflets narrowly deltoid lanceolate, apex acuminate, base rounded to cordate; margin flat; leaflets coriaceous, glossy adaxially and dull abaxially, dark green when fresh, drying olive green to brown on both sides; on abaxial surface the midvein prominent, secondary veins inconspicuous; on adaxial surface the midvein, secondary and tertiary veins discolorous (yellow when fresh). Flowers unknown. Infructescences short, $1.7-2.2 \times 0.2 \mathrm{~cm}$. Fruits $6.5-7$ x $5 \mathrm{~mm}$, obovoid, pedicel clavate, $1-1.5 \mathrm{~mm}$ long, mature exocarp green except slightly red at the apex, smooth, dehiscing via three valves; pseudaril bright orange-red, thin, covering the entire pyrene; pyrene $5-5.5 \times 3.5-4.5 \mathrm{~mm}$, essentially obovoid, trigonous, with flat sides, beige. Cotyledons and germination unknown.

Distribution and ecology.-Bursera shaferi is a Cuban endemic that occurs on limestone hills (mogotes) in scrubland and semi-deciduous forests. Associated flora includes Amyris elemifera 
L., Casearia mollis Kunth, Dioscorea sp., Erythroxylum havanense Jacq., Selenicereus sp., and Thrinax morrissi $\mathrm{H}$. Wendl.

Leaf architecture.--Secondary vein fabric simple brochidodromous, spacing irregular, uniform, attachment excurrent; interior secondaries parallel to major secondaries, inter-secondaries ca. 1 per intercostal area, $>50 \%$ length of subjacent secondary, distal course parallel to subjacent major secondary; intercostal tertiary veins alternate percurrent, angle inconsistent; epimedial tertiary veins ca. 1 per intercostal area, reticulate, exterior tertiary course variable (looped or terminating at the margin); quaternary vein fabric irregular reticulate; areolation well developed; FEVs dendritically 2+-branched, terminating in highly branched sclereids, marginal ultimate venation looped.

Leaf anatomy.-Leaves isostomatic, palisade parenchyma well developed and tight, ca. $40 \mu$ thick; spongy parenchyma well developed, ca. $45 \mu$ thick. Crystals hexagonal and rhomboid, abundant on primary vein and lamina. Primary vein with three resin canals abaxially and one adaxially.

Distribution and ecology.-Bursera shaferi is a Cuban endemic that occurs on limestone hills (mogotes) in scrubland and semi-deciduous forests. Associated flora includes Amyris elemifera L., Casearia mollis Kunth, Dioscorea sp., Erythroxylum havanense Jacq., Selenicereus sp., and Thrinax morrissi $\mathrm{H}$. Wendl.

Additional specimens examined. CUBA. Camaguey: Cayo Romano, Punta Cayo La Moca, 16 Sep 1984, Moncada 36091(HAC). Las Tunas: 4 km E of Punta Piedra de Mangle, 9 Oct 1986, del Risco 37438 (HAC). Pinar del Río: Viñales, Mogote de la Bandera, 21 Feb 1953, Alain 14988 (HAC); Viñales, Mogote de la Bandera, Ensenada de Los Muertos, 29 Mar 1953, Alain 14989 (HAC); Sumidero, 24 Nov 1923, Ekman 2809 (HAC); Sierra de Viñales, 13 Jul 1923 (fr), 
Ekman 16699 (HAC); Carretera a Puerto Esperanza, km 30, mogote al lado de la carretera, 18 Jun 2008, Martinez-Habibe et al. 2239 (NY, RSA), 18 Jun 2008, Martínez-Habibe et al. 2240 (NY, RSA).

Bursera spinescens Urb. \& Ekman in Ark. Bot. 22A(8): 57. 1928. Commiphora spinescens (Urb. \& Ekman) Borhidi, Acta Bot. Hung. 37:77. 1992.Type: HAITI. Massif de la Selle, gr. Morne des Commissaires, prope Anses-à-Pitre, 15 Sep 1926 (fr), Ekman 6977 (holotype: H[designated here]; isotypes: $\mathrm{K}, \mathrm{IJ})$.

Shrub, 1.5-2 m tall, highly branched. Bark grayish, close, branches pale brown, branch apices thorn-like. Leaves simple, distal or agglomerated on short shoots, held vertical, petiole $0.5-1$ mm long, lamina 5-10 x 3.5-5 mm, oblong-elliptic, symmetric, thick and coriaceous, almost succulent, glossy green, apex and base rounded, drying pale green on both sides; on both sides the primary and secondary veins prominulous.Inflorescences axillary, very short, 1-5-flowered; staminate inflorescences $3.5-4.5 \mathrm{~mm}$ long, $1.2-1.6 \mathrm{~mm}$ diam at base, shorter than the leaves, pedicel short, 1-1.5 mm long; pistillate infructescences (pistillate inflorescences unknown) 0.8 $1 \mathrm{~cm}$ long, $2 \mathrm{~mm}$ diam at base, peduncles $0.7-1 \mathrm{~mm}$ long. Staminate flowers $2.5-3 \mathrm{~mm}$ long; perianth 3-merous; calyx 1.2-1.4 x $0.6 \mathrm{~mm}$ overall, taller than the disk, shallowly cupular, the lobes $0.5 \times 0.4 \mathrm{~mm}$, deltate, separated by a short flat sinus ca. $0.3 \mathrm{~mm}$, apex acute; petals $2.5-2.7 \times 1.1-$ $1.3 \mathrm{~mm}$, oblanceolate, erect, creamy-white, fleshy, with an inconspicuous inflexed apiculum 0.2 mm long; stamens diplostemonous, in two equal series, $1.7 \mathrm{~mm}$ long with dorsifixed anthers 0.9 $1.1 \mathrm{~mm}$ long, oblong-elliptic in dorsiventral and lateral views, filaments, strap-shaped, fleshy; disk $0.3 \mathrm{~mm}$ tall, $0.3 \mathrm{~mm}$ thick, annular, sulcate; pistillode reduced to a small mound of tissue $0.2 \times 0.2$ $\mathrm{mm}$ in center of disk, , without rudimentary styles. Fruiting pedicel 4-6 mm long, slightly clavate, green:fruits $5-6$ x $4 \mathrm{~mm}$, green with reddish-purple tip or sometimes completely red, obliquely 
ovoid to subglobose, apex slightly acute, base rounded; pyrene 4 x $3 \mathrm{~mm}$, elliptic, trigonous with flat sides, beige. Cotyledons and germination unknown.

Leaf architecture.-Major secondary framework festooned semi-craspedodromous with major secondary spacing irregular and angle inconsistent, major secondary attachment to the midvein decurrent; inter-seondary veins, $<1$ per intercostal area, perpendicular to secondary veins, reticulating; intercostal tertiary vein fabric transversely ramified; exterior tertiary course looped or terminating at the margin; areolation poorly developed; quaternary vein fabric freely ramifying; FEVs 2+-branched, terminating in tracheoid idioblasts; marginal ultimate venation spiked.

Leaf anatomy.-Leaves amphistomatic, leaf thickness equal (no midvein distinguishable), ca. $130 \mu$; palisade parenchyma uniseriate on the adaxial side, $20-30 \mu$, tight, palisade parenchyma $2-$ 3 -seriate on the abaxial side, $70-90 \mu$, very tight, spongy parenchyma well developed and lax, 60 $70 \mu$. Crystals hexagonal and rhomboid scattered along the lamina. Primary vein with one resin canal.

Distribution and ecology.-Bursera spinescens occurs in low thorn-scrub over dogtooth limestone, restricted to the southernmost region of Hispaniola in the neighboring provinces of Jimaní (Haiti) and Barahona and Pedernales (Dominican Republic). Some associated flora includes Arcoa sp., Bursera simaruba (L.) Sarg.,Catalpa macrocarpa Ekman, Comocladia spp., Coccothrinax ekmanii Burret, Eugenia sp., Fluggea sp., Guaiacum officinale L., Haitiella ekmanii (Burret) L. H. Bailey, Opuntia sp., Metopium sp., Phyllostylon rhamnoides (J. Poiss.) Taub.,Pimenta haitiensis (Urb.) Landrum, Reynosia sp., Savia sp., and Ziziphus sp.

Conservation status. - B. spinescens has not been assessed by the IUCN, but its restricted distribution in a single dry forest suggests that it should be considered at least a vulnerable species. 
Bursera spinescens is the only species of Bursera in the Caribbean region with thorny short shoots, making it easy to distinguish. Additionally, B. spinescens has small simple leaves that are also smaller than Hispaniolan B. trinitensis (5-10 x 3.5-5 mm vs. $1.5-2.5$ x 1-1.6 cm, respectively). Borhidi (1992) proposed the combination Commiphora spinescens based solely on a previous study by Moncada (1989) of Cuban Bursera, without examining plant material. The present study reinstates this species as Bursera based on molecular DNA sequence data (see chapter one) as well as the morphological and anatomical characters presented above.

Additional specimens examined. DOMINICAN REPUBLIC. Barahona: Sierra de Bahoruco, approx. $19 \mathrm{~km}$ al NO del poblado Higuero, O de El Tunal, camino a Los Jobitos, Hoyo de Pelempito, $18^{\circ} 03^{\prime} 30^{\prime}$ N, 71²5’00”W, 450 m, 8 Jun 1995 (fl\&fr), García et al. 4876 (NY).

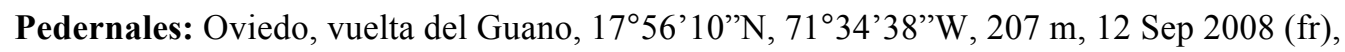
Martínez-Habibe \& Clase2284 (JBSD, RSA, NY); Isla Beata, $2.5 \mathrm{~km}$ al este del campamento de la Marina de Guerra, $17^{\circ} 36^{\prime} 30^{\prime}{ }^{\prime}, 7^{\circ} 31^{\prime} 00^{\prime \prime} \mathrm{W}, 25-30$ m, 30 Aug 1985 (fr), García \& Pimentel 489 (NY); área de Cabo Rojo, Minas Nuevas de la Ideal Dominicana, $17^{\circ} 55^{\prime} \mathrm{N}, 71^{\circ} 38^{\prime} \mathrm{W}, 50 \mathrm{~m}, 4 \mathrm{Nov}$ 1988 (fr), Czerwenka 2711 (FTG, JBSD); ca $9.6 \mathrm{~km} \mathrm{~S}$ of Las Mercedes, on road connecting Las

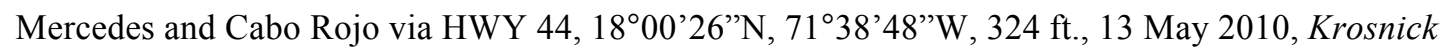

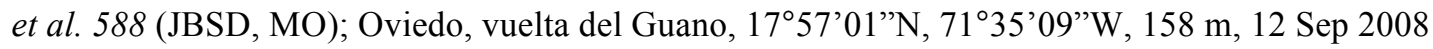
(§łfl), Martínez-Habibe \& Clase 2287 (JBSD, RSA, NY); Cabo Rojo, Los Pozos, próximo al punto

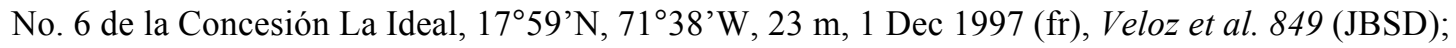
entre Sabila y la Sabana de Cacheo, al sur de Manuel Goya (de Oviedo), $17^{\circ} 50 \mathrm{~N}, 71^{\circ} 30 \mathrm{~W}, 150$ 200 m, 10 Jun 1986, Zanoni et al. 36559 (FTG, JBSD); 1 km al N del Cruce de Cabo Rojo,

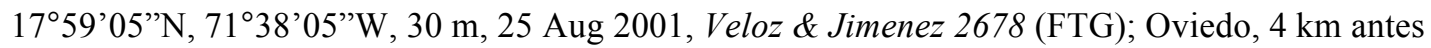
de la vuelta del Guano, 29 Jun 2006 (fl\&fr), Veloz et al. 4046 (FTG, JBSD). 
Bursera trinitensis R.O.Williams, F1. Trinidad \& Tobago I. 153 (1929). Elaphrium trinitensis Rose, Bull. Torrey Bot. Club 48: 333. 1922. Type: TRINIDAD. Western end of Monos Island, 4 Apr 1921 (fl, fr), Britton, Britton \& Brown 2739 (holotype: NY, 2 sheets [designated here]; isotypes: K, US).

Bursera ovata Urb. \& Ekman in Ark. Bot. 22(8): 57. 1928. Commiphora ovata (Urb. \& Ekman) Borhidi, Acta Bot. Hung. 37:77. 1992. Type: DOMINICAN REPUBLIC. Barahona, Santo Domingo, prope Anse-à-Chaud, 21 Sep 1926 (fl, fr), Ekman 7001 (holotype: S [designated here]; isotype: US).

Shrubs or small trees to $6 \mathrm{~m}$ tall. Bark gray, close. Branches gray, reddish distally, with sparse rounded lenticels and abundant short shoots. Leaves $1.5-2.5$ x 1-1.6 cm, simple, agglomerated at the end of the short shoots; petiole $1.7-5 \mathrm{~mm} \times 0.4 \mathrm{~mm}$ diam, reddish at the base; ovate, lamina apex obtuse, base rounded, membranaceous, glossy green adaxially, dull pale green abaxially, drying pale green on both surfaces, on both surfaces the midvein and secondary veins prominent. Inflorescences along short shoots, dimorphic, very short; staminate inflorescences 10 16-flowered, $12-16 \mathrm{~mm}$ long, $0.2-0.5 \mathrm{~mm}$ diam at base, shorter than the leaves, pedicel short, $2-2.5$ $\mathrm{mm}$ long; pistillate inflorescences $1-3$-flowered, $0.8-1.2 \mathrm{~cm}$ long, $1 \mathrm{~mm}$ diam at base. Staminate flowers $1.5-2 \mathrm{~mm}$ long; perianth 5-merous; calyx $1.2-1.4 \times 0.5 \mathrm{~mm}$ overall, taller than the disk, shallowly cupular, the lobes $0.7 \times 0.6 \mathrm{~mm}$, deltate, apex acute; petals $2.4-2.6 \times 1.1-1.3 \mathrm{~mm}$, oblanceolate, erect, thin, with an inconspicuous inflexed apiculum $0.2 \mathrm{~mm}$ long; stamens $1.7 \mathrm{~mm}$ long with dorsifixed anthers $0.9-1.1 \mathrm{~mm}$ long, oblong-elliptic in dorsiventral and lateral views, filaments, strap-shaped; disk inconspicuous, $0.3 \mathrm{~mm}$ tall, $0.1 \mathrm{~mm}$ thick, annular; pistillode reduced to a small mound of tissue $0.2 \times 0.2 \mathrm{~mm}$ in center of disk, without rudimentary styles. Fruiting pedicel 4-5 mm long, clavate, green; fruits 5-6 x 4-4.5 mm, green with reddish-purple tip or 
sometimes completely red, obliquely ovoid to subglobose, apex and base rounded; pyrene $4-5 \times 3$ mm, elliptic, trigonous with flat sides, beige. Cotyledons and germination unknown.

Leaf architecture.--Secondary vein fabric simple brochidodromous, secondary vein angle acute and uniform, spacing irregular, intersecondary veins $<1$ per intercostal area, parallel to major secondaries, reticulating distally; intercostal tertiaries irregular- reticulate, quaternary veins freely ramified, areolation poorly developed, FEVs dendritically 2+-branched, terminating in tracheoid idioblasts, marginal ultimate venation incompletely looped.

Leaf anatomy.-Leaves isostomatic, palisade parenchyma uniseriate, $60-80 \mu$,very tight,

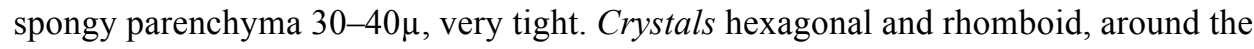
midvein.Primary vein with four abaxial resin canals.

Distribution and ecology.- Known from Pedernales and Barahona provinces in the Dominican Republic, and from a single collection in Trinidad, in dry forest on dogtooth low scrub. Flowering specimens have been collected in May to June and fruiting specimens in June to September. Associated flora includes Acacia scleroxyla Tuss., Catalpa macrocarpa Ekman, Comocladia sp., Consolea sp., Cordia sp., Eugenia rhombea (O.Berg.) Krug \& Urb., Guaiacum sanctum L., Lonchocarpus sp., and Prosopis juliflora (Sw.) DC.

Conservation status. - B. trinitensis has not been assessed by the IUCN, but its restricted distribution in a single dry forest and very few collections suggest that it should be considered at least a vulnerable species.

B. trinitensis is the only species of Bursera in Hispaniola with ovate membranaceous leaves and short shoots not ending in thorns. The only other species of the region with non-spiny short shoots is Cuban B. shaferi, but its leaves are narrowly deltate-lanceolate. As with most Hispaniolan species, B. ovata has been poorly collected, currently represented by only one flowering specimen 
with few male flowers. The Dominican material referred to $B$. ovata cannot be distinguished from B. trinitensis, which was based on a single collection from Trinidad (apparently extinct on that island), and the latter has priority.

Additional specimens examined. DOMINICAN REPUBLIC. Azua: $1.5 \mathrm{~km}$ después del balneario de Monte Río, camino hacia La Vigía, 18²3’83”N, 7042`50”W, 10-30 m, 21 Jun 2001 (male fl), Clase et al. 2996 (JBSD); Sierra Martín Gracía, sección Barreras, entre Barreras y El Sorbedero, $18^{\circ} 17^{\prime} 28^{\prime \prime} \mathrm{N}, 70^{\circ} 53^{\prime} 06^{\prime \prime} \mathrm{W}, 10-15 \mathrm{~m}, 8$ May 2001 (fl), Peguero et al. 2473 (JBSD); Sierra Martín García, oeste de El Sorbedero, 18¹8’02”N, 7053’42”W, 60-65 m, 9 May 2001 (fl), Peguero et al. 2526 (JBSD); Pedernales: Parque Nacional Jaraguas, Bahía de Las Aguilas, side of dirt road heading up shallow hillside ca. $600 \mathrm{ft}$. From main parking área, $17^{\circ} 52^{\prime} 05^{\prime \prime} \mathrm{N}, 71^{\circ} 38^{\prime} 40^{\prime \prime} \mathrm{W}$, 57 ft., 14 May 2010 (fr), Krosnick et al. 594 (MO); Parque Nacional Jaraguas, Bahía de Las Aguilas, $17^{\circ} 51^{\prime} 57^{\prime}{ }^{\prime} \mathrm{N}, 71^{\circ} 38^{\prime} 29^{\prime}$ 'W, $40 \mathrm{~m}, 12$ Sep 2008 (fr), Martínez-Habibe \& Clase 2288 (JBSD, NY, RSA); Jaragua National Park, ca. 400 E of reserve guard station at Bahia de Las Aguilas, 2 Jun 2000 (st), Trejo-Torres \& Currás 1595 (UPRRP); Cabo Rojo, 45 m, 2 Feb 1997 (st), Veloz et al. 895-A (JBSD).

Bursera yaterensis M. C. Martínez, Daly, \& J. Pérez sp. nov. Type. Cuba: Guantanamo, Imías, carretera a Yateritas, 16 Jun 2008(fr), M. C. Martínez-Habibe, J. Pérez-Camacho, P. Herrera \& M. Cañizares-Morera 2237 (holotype: NY; isotypes: HAC, RSA).

Suffrutices $0.5 \mathrm{~m}$, rarely a shrub up to $1.8 \mathrm{~m}$., densely branching. Leaves $3-4 \mathrm{~cm}$ long, 1foliolate; petiole $3-4 \mathrm{~mm} \times 0.7 \mathrm{~mm}$ diam; chartaceous, drying pale green, narrowly oblong-elliptic to oblong, symmetric; leaflet apex obtuse, abruptly and narrowly short-acuminate, base rounded, symmetric; on abaxial surface the midvein broadly prominulous, ca. $2 \mathrm{~mm}$ wide at base and 
narrowing towards the tip, pale yellow, secondary veins prominulous, rest of venation not visible; on adaxial surface the midvein narrowly prominulous and sometimes sunk in a groove, rest of venation not visible. Inflorescences to $2.6 \mathrm{~cm}$ long x $0.5-0.9 \mathrm{~mm}$ diam at base, racemose; bracteoles $0.8-1.1 \mathrm{~mm}$ long, subulate, deciduous; pedicel $1.1-1.3 \times 0.3-0.4 \mathrm{~mm}$. Staminate flowers 5-merous, $3-5 \mathrm{~mm}$ long at anthesis, calyx $0.8-1.1 \times 1.3-1.6 \mathrm{~mm}$ overall, narrowly copular, the lobes $0.5-0.8$ long, triangular; petals $3.5-3.8 \times 1.2-1.5 \mathrm{~mm}$, oblanceolate and narrowed at the base, suberect at anthesis, the margin involute, dorsally slightly carinate, the inflexed apiculum $0.3 \mathrm{~mm}$ long; stamens $10,1.9-2.1 \mathrm{~mm}$ long, the anthers $1.2-1.4 \mathrm{~mm}$ long, oblong in dorsiventral view, elliptic in lateral view, in two equal series; disk annular, undulate, $0.3-0.5 \mathrm{~mm}$ tall $\times 0.2 \mathrm{~mm}$ thick; pistillode in a narrowly concave receptacle, reduced to an ovoid mound of tissue, $0.3 \mathrm{~mm}$ long, surmounted by 3 suberect lobules $0.1 \mathrm{~mm}$ long. Pistillate flowers unknown. Fruit unknown. Cotyledons and germination unknown.

Leaf architecture.-Secondary vein fabric simple brochidodromous, secondary vein angle acute and uniform, spacing regular, intercostal tertiaries admedially ramified, epimedial tertiaries ramified, quaternary veins freely ramified, areolation poorly developed, FEVs dendritically 2+branched, terminating in tracheoid idioblasts, marginal ultimate venation incomplete loops.

Leaf anatomy.-Leaves amphistomatic, two layers of palisade parenchyma, the adaxial palisade $80-100 \mu$, the abaxial ca. $30 \mu$; spongy parenchyma less developed. Crystals hexagonal and rhomboid, scattered. Primary vein with four resin canals.

Distribution and ecology.-It is endemic to xeromorphic coastal scrub that develops in the cavities in karst (dogtooth limestone) substrates in Guantanamo Province, Cuba. The vegetation consists mostly of suffrutices and small shrubs $1-1.5 \mathrm{~m}$ tall featuring Agave albescens Trel., Jacquemontia spp., and Pictetia sp. The species is known to flower in June. 
The species closest to B. yaterensis is B. glauca. Besides the differences in number of leaflets (mostly unifoliolate vs. 3-7-foliate), they can be distinguished by petiole length and few other leaf architecture characters (Table 7).

Additional specimens examined. CUBA. Guantánamo: Guantánamo Bay, 17-30 Mar 1909, Britton (HAC 2037); Imías, carreteta a Yateritas, 16 Jun 2008, Martínez-Habibe et al. 2235 (NY, RSA); Imías, carreteta a Yateritas, 16 Jun 2008, Martínez-Habibe et al. 2236 (NY, RSA); Imías, km 80, Jan 1956, Morton. (HAC 20184); San Antonio del Sur, carretera entre Tortuguilla e Imías, 1 km antes de Los Naranjos, 16 Jun 2008, Martínez-Habibe et al. 2238 (NY, RSA).

Table 7. Characters that separate B. glauca from B. yaterensis

\begin{tabular}{lll} 
& B. yaterensis & B. glauca \\
\hline \# leaflets & $1(3)$ & $3-7$ \\
Petiole length & $<1 \mathrm{~cm}$ & $1-3 \mathrm{~cm}$ \\
Leag base angle & obtuse & acute/obtuse \\
Perimarginal vein & not visible & absent \\
Inter-secondary proximal course & transiallel to major secondaries \\
Intercostal tertiary vein fabric & admedially ramified & Hispaniola, rest of Cuba \\
Distribution & Guantanamo & \\
\hline
\end{tabular}




\section{LITERATURE CITED}

BALDWIN B. G. AND S. MARKOS. 1998. Phylogenetic Utility of the External Transcribed Spacer (ETS) of 18S-26S rDNA: Congruence of ETS and ITS Trees of Calycadenia(Compositae). Molecular phylogenetics and evolution 10: 449-463.

BECERRA J. X. 2003. Evolution of Mexican Bursera (Burseraceae) inferred from ITS, ETS, and 5S nuclear ribosomal DNA sequences. Molecular phylogenetics and evolution 26: 300-309.

BECERRA J. X. AND J. SARUKHÁN. 2005. Timing the Origin and Expansion of the Mexican Tropical Dry Forest. Proceedings of the National Academy of Sciences of the United States of America 102: pp. 10919-10923.

BÉCQUER-GRANADOS E., K. NEUBIG, W. JUDD, F. MICHELANGELI, J. ABBOTT, AND D. PENNEYS. 2008. Preliminary Molecular Phylogenetic Studies in \&lt;i\&gt;Pachyanthus\&lt;/i\&gt; (Miconieae, Melastomataceae). The Botanical Review 74: 37.

BORHIDI A. 1992. New names and new species in the flora of Cuba and the Antilles: 4. Acta Botanica Hungarica 37: 75.

BORHIDI A. 1997. Phytogeography and vegetation ecology of Cuba. Akadémiai Kiadó., Budapest, Hungary.

BRIGGS J. C. 1984. Freshwater Fishes and Biogeography of Central America and the Antilles. Systematic zoology 33: pp. 428-435.

BULLOCK A. A. 1936. Notes on the Mexican species of Bursera. Bulletin Miscelaneous Info $346-387$. 
CARLQUIST, S. 1966. The biota of long-distance dispersal. III. Loss of dispersibility in the Hawaiian flora. Brittonia 18 (4): 310-335.

CHAKRABARTY P. 2006. Systematics and historical biogeography of Greater Antillean Cichlidae. Molecular phylogenetics and evolution 39: 619-627.

CHIAPPY C., P. HERRERA-OLIVER, AND L. IÑIGUEZ. 1988. Aspectos botánicos y valores para la conservación de la naturaleza de la llanura costera del norte de la Provincia de Las Tunas, Cuba. Acta Botánica Cubana 61: 1.

CREWS S. C. AND R. G. GILLESPIE. 2010. Molecular systematics of Selenops spiders (Araneae: Selenopidae) from North and Central America: implications for Caribbean biogeography. Biological Journal of the Linnean Society 101: 288-322.

DALY, D. C., HARLEY, M. M., MARTINEZ-HABIBE, M. C. AND A. WEEKS. 2011. Burseraceae. In: Kubitzki, K. (ed.). The families and genera of vascular plants. Vol. X. Flowering plants. Eudicots: Sapindales, Cucurbitales, Myrtaceae. Springer-Verlag, Berlin.

DE LA LUZ, JOSÉ LUIS LEÓN AND J. J. PÉREZ-NAVARRO. 2010. DOS NUEVOS TAXA DE BURSERA (BURSERACEAE) DE BAJA CALIFORNIA SUR, MÉXICO. (Spanish). Acta Botanica Mexicana 37-49.

DE-NOVA J. A., R. MEDINA, J. C. MONTERO, A. WEEKS, J. A. ROSELL, M. E. OLSON, L. E. EGUIARTE, AND S. MAGALLÓN. 2011. Insights into the historical construction of speciesrich Mesoamerican seasonally dry tropical forests: the diversification of Bursera (Burseraceae, Sapindales). New Phytologist: 2316. 
DOMNING D. P., R. J. EMRY, R. W. PORTELL, S. K. DONOVAN, AND K. S.

SCHINDLER. 1997. Oldest West Indian Land Mammal: Rhinocerotoid Ungulate from the Eocene of Jamaica. Journal of Vertebrate Paleontology 17: pp. 638-641.

DOYLE J. J. AND J. L. DOYLE. 1987. A rapid DNA isolation procedure for small quantities of fresh leaf material. Phytochemical Bulletin 19: 11-15.

DRUMMOND A. J., B. ASHTON, M. CHEUNG, J. HELED, M. KEARSE, R. MOIR, S. STONES-HAVAS, T. THIERER, AND A. WILSON. 2009. Geneious v5.0.3. .

DRUMMOND A. J. AND A. RAMBAUT. 2006. Bayesian evolutionary analysis by sampling trees. BMC Evolutionary Biology 7: 214.

DRUMMOND A. J., S. Y. W. HO, M. J. PHILLIPS, AND A. RAMBAUT. 2006. Relaxed phylogenetics and dating with confidence. 4: e88. PLoS Biology 4: e88.

EDGAR R. C. 2004. MUSCLE: Multiple sequence alignment with high accuracy and high throughput. Nucleic Acids Research 32: 1792.

FARRIS J. S., M. KALLERSJO, A. G. KLUGE, AND C. BULT. 1995. Constructing a Significance Test for Incongruence. Systematic Biology 44: pp. 570-572.

FRANCISCO-ORTEGA J., E. SANTIAGO-VALENTÍN, ACEVEDO-RODRÍGUEZ, P. LEWIS, C. L., J. PIPOLY III, A. W. MEEROW, AND M. MAUNDER. 2007. Seed plant genera endemic to the Caribbean island biodiversity hotspot: a review and a molecular Phylogenetic Perspective. Botanical Review 73: 183. 
GAYET M., J. C. RAGE, T. SAMPERE, AND P. Y. GAGNIER. 1992. Modalité des exchanges de vertebrés continentaux entre l'Amerique du Nord et l'Amerique du Sud au Cretacé superior et au Paleocene. Bulletin de la Société Géologique de France 163: 781.

GILLETT J. B. 1980. Commiphora (Burseraceae) in South America and Its Relationship to Bursera. Kew Bulletin 34: 569-587.

GRADSTEIN F. M., J. G. OGG, A. G. SMITH, W. BLEEKER, AND L. J. LOURENS. 2004. A geologic time scale. Columbia University Press, New York, NY.

GRAHAM A. 2003. Historical Phytogeography of the Greater Antilles. Brittonia 55: pp. 357383.

GUEVARA-FÉFER F. 2010. UNA NUEVA ESPECIE DE BURSERA (BURSERACEAE), ENDÉMICA DE LA CUENCA BAJA DEL RÍO BALSAS EN LOS ESTADOS DE MICHOACÁN Y GUERRERO, MÉXICO. (Spanish). Acta Botanica Mexicana119-128.

HALL J., R. K. ROBBINS, AND D. J. HARVEY. 2004. Extinction and Biogeography in the Caribbean: New Evidence from a Fossil Riodinid Butterfly in Dominican Amber. Proceedings: Biological Sciences 271: pp. 797-801.

HEDGES S. B. 2006. Paleogeography of the Antilles and Origin of West Indian Terrestrial Vertebrates. Annals of the Missouri Botanical Garden 93: pp. 231-244.

HILLIS D. M. AND J. J. BULL. 1993. An Empirical Test of Bootstrapping as a Method for Assessing Confidence in Phylogenetic Analysis. Systematic Biology 42: pp. 182-192.

HOWARD R. A., E. S. KELLOGG, AND G. W. STAPLES. 1988. In Anonymous Flora of the Lesser Antilles, vol. 4, Arnold Arboretum, Harvard University, Jamaica Plain, MA. 
ITURRALDE-VINENT M. A. 2006. Meso-Cenozoic Caribbean Paleogeography: Implications for the Historical Biogeography of the Region. International Geology Review 48: 791.

ITURRALDE-VINENT M. AND R. D. E. MACPHEE. 1999. Paleogeography of the Caribbean region : implications for Cenozoic biogeography. Bulletin of the American Museum of Natural History.

JESTROW B., G. PROCTOR, AND J. FRANCISCO-ORTEGA. 2008. Lasiocroton trelawniensis (Euphorbiaceae), a Critically Endangered Species from the Cockpit Country of Jamaica, Belongs to Bernardia (Euphorbiaceae). Botanical Review 74: 166.

LIOGIER A. H. 1983. La Flora de La Española. II. Burseraceae. Serie Cientifica 44.

MACPHEE R. D. E. AND M. A. ITURRALDE-VINENT. 1995. Origin of the Greater Antillean land mammal fauna, 1: New Tertiary fossils from Cuba and Puerto Rico. Am Mus Novitates $31 \mathrm{pp}$.

MACPHEE R. D. E. AND M. ITURRALDE-VINENT. 2000. A short history of Greater Antillean land mammals: Biogeography, paleogeography, radiations, and extinctions Tropics 10: 145.

MCKENNA M. C. 1973. Sweepstakes, filters, corridors, Noah’s ark, and beached viking funeral ships in paleogeography. In Tarling D. H. and S. K. Runcorn [eds.], Implications of continental drift to the earth sciences, 293-306. Academic Press, London, UK.

MCVAUGH R. AND J. RZEDOWSKY. 1965. Synopsis of the genus Bursera L. in western México, with notes on the material of Bursera collected by Sessé \& Mociño. Kew Bulletin 18: 317 382. 
MONCADA-FERRERA M. 1989. Reporte del género Commiphora Jacq. (Burseraceae) para Cuba. Revista del Jardin Botanico Nacional X: 3-9.

MULLER K. 2005. The efficiency of different search strategies in estimating parsimony jackknife, bootstrap, and Bremer support. BMC Evolutionary Biology 5: 58.

OLSON M. E. 2002. Combining Data from DNA Sequences and Morphology for a Phylogeny of Moringaceae (Brassicales). Systematic Botany 27: pp. 55-73.

OXELMAN B. AND M. LIDÉN. 1997. Chloroplast rps16 intron phylogeny of the tribe Sileneae (Caryophyllaceae). Plant Systematics and Evolution 206: 393.

PINDELL J. L. 1994. Evolution of the gulf of Mexico and the Caribbean. In Donovan S. K. and T. A. Jackson [eds.], Caribbean Geology: An Introduction. pp.13-39. University of the West Indies Publishers’ Association, Kingston. Jamaica.

PINDELL J. L. AND S. F. BARRETT. 1990. Geological evolution of the caribbean region: A plate-tectonic perspective. In Dengo G. and J. E. Case [eds.], The geology of North America, vol. $\mathrm{H}$, the Caribbean region, Geological Society of America.

PITMAN W. C., S. C. CANDE, J. LABREQUE, AND J. L. PINDELL. 1993. Fragmentation of gondwana: The separation of africa from south america. In Goldblatt P. [ed.], Biological relationships between Africa and South America, 817. Yale University Press, New Haven.

POINAR G. O. AND D. C. CANNATELLA. 1987. An Upper Eocene Frog from the Dominican Republic and its Implication for Caribbean Biogeography. Science 237: pp. 1215-1216.

POSADA D. AND K. CRANDALL. 1998. MODELTEST: testing the model of DNA substitution. Bioinformatics 14: 817-818. 
RAMBAUT A. 2006-2009. Tree Figure Drawing Tool Version 1.3.1.

RICKLEFS R. AND E. BERMINGHAM. 2008. The West Indies as a laboratory of biogeography and evolution. Philosophical transactions of the Royal Society of London.Series B, Biological sciences 363: 2393-2413.

RONCAL J., S. ZONA, AND C. E. LEWIS. 2008. Molecular Phylogenetic Studies of Caribbean Palms (Arecaceae) and Their Relationships to Biogeography and Conservation. The Botanical Review 74: 78.

RONQUIST F. AND J. P. HUELSENBECK. 2003. MrBayes 3: Bayesian phylogenetic inference under mixed models. Bioinformatics 19: 1572-1574.

ROSELL J. A., M. E. OLSON, A. WEEKS, J. A. DE-NOVA, R. M. LEMOS, J. P. CAMACHO, T. P. FERIA, R. GOMEZ-BERMEJO, J. C. MONTERO, AND L. E. EGUIARTE. 2010. Diversification in species complexes: Tests of species origin and delimitation in the Bursera simaruba clade of tropical trees (Burseraceae). Molecular phylogenetics and evolution.

RZEDOWSKI J. AND F. GUEVARA-FÉFER. 1992. Familia Burseraceae. Flora del Bajio y de Regiones Adyacentes. 3: 1-46.

RZEDOWSKI J. AND E. ORTIZ. 1988. ESTUDIOS QUIMIOTAXONOMICOS DE BURSERA (BURSERACEAE). II. UNA ESPECIE NUEVA DE ORIGEN HIBRIDO DE LA BARRANCA DE TOLANTONGO, ESTADO DE HIDALGO. (Spanish). Acta Botanica Mexicana11-19.

RZEDOWSKI J. AND H. KRUSE. 1979. Algunas tendencias evolutivas en Bursera (Burseraceae). Taxon 28: pp. 103-116. 
RZEDOWSKI J. AND D. R. CALDERÓN. 2000a. UNA ESPECIE NUEVA DE BURSERA (BURSERACEAE) DEL ESTADO DE OAXACA (MÉXICO). (Spanish). Acta Botanica Mexicana75-81.

RZEDOWSKI J. AND D. R. CALDERÓN. 2000b. TRES ESPECIES NUEVAS DE BURSERA (BURSERACEAE) DE LA REGIÓN COSTERA DEL OCCIDENTE DE MÉXICO. (Spanish). Acta Botanica Mexicana 47-59.

RZEDOWSKI J. AND D. R. CALDERÓN. 2002. DOS ESPECIES NUEVAS DE BURSERA (BURSERACEAE) DEL ESTADO DE OAXACA (MÉXICO). (Spanish). Acta Botanica Mexicana $81-90$.

RZEDOWSKI J. AND D. R. CALDERÓN. 2006. DOS ESPECIES NUEVAS DE BURSERA (BURSERACEAE) DE MÉXICO. (Spanish). Acta Botanica Mexicana169-178.

RZEDOWSKI J. AND G. C. DE RZEDOWSKI. 2008. DOS ESPECIES NUEVAS DE BURSERA (BURSERACEAE) DE LOS ESTADOS DE GUERRERO, MICHOACÁN Y OAXACA (MÉXICO). (Spanish). Acta Botanica Mexicana75-85.

RZEDOWSKI J., R. MEDINA LEMOS, AND D. R. CALDERÓN. 2005. INVENTARIO DEL CONOCIMIENTO TAXONÓMICO, ASÍ COMO DE LA DIVERSIDAD Y DEL ENDEMISMO REGIONALES DE LAS ESPECIES MEXICANAS DE BURSERA (BURSERACEAE). (Spanish). Acta Botanica Mexicana: 85-111.

RZEDOWSKI J., R. MEDINA LEMOS, AND D. R. CALDERÓN. 2007. SEGUNDA RESTAURACIÓN DE BURSERA OVALIFOLIA Y NOMBRE NUEVO PARA OTRO COMPONENTE DEL COMPLEJO DE B. SIMARUBA (BURSERACEAE). (Spanish). Acta Botanica Mexicana45-70. 
RZEDOWSKI J., R. MEDINA LEMUS, AND D. R. CALDERÓN. 2004. LAS ESPECIES DE BURSERA (BURSERACEAE) EN LA CUENCA SUPERIOR DEL RÍO PAPALOAPAN

(MÉXICO). (Spanish). Acta Botanica Mexicana23-147.

SANG T., D. J. CRAWFORD, AND T. F. STUESSY. 1997. Chloroplast DNA Phylogeny, Reticulate Evolution, and Biogeography of Paeonia (Paeoniaceae). American Journal of Botany 84: pp. $1120-1136$.

SANTIAGO-VALENTN E. AND J. FRANCISCO-ORTEGA. 2008. Plant Evolution and Biodiversity in the Caribbean IslandsPerspectives from Molecular Markers. The Botanical Review 74: 1 .

SHAW J., E. B. LICKEY, AND E. E. SCHILLING. 2007. Comparison of Whole Chloroplast Genome Sequences to Choose Noncoding Regions for Phylogenetic Studies in Angiosperms: The Tortoise and the Hare III. American Journal of Botany 94: 275.

SWOFFORD D. L. 2002. PAUP* Phylogenetic Analysis Using Parsimony (* and Other Methods). .

THORNE R. 1996. Some guiding principles of biogeography. Telopea 6: 845 .

VAN EE B. W., P. E. BERRY, AND R. RIINA. 2008. Molecular Phylogenetics and Biogeography of the Caribbean-Centered Croton Subgenus Moacroton (Euphorbiaceae s.s.). The Botanical Review 74: 132.

WEEKS A. AND B. SIMPSON. 2004. Molecular genetic evidence for interspecific hybridization among endemic Hispaniolan Bursera (Burseraceae). American Journal of Botany 91 : 976-984. 
WEEKS A., D. C. DALY, AND B. B. SIMPSON. 2005. The phylogenetic history and biogeography of the frankincense and myrrh family (Burseraceae) based on nuclear and chloroplast sequence data. Molecular phylogenetics and evolution 35: 85-101.

WEEKS A. AND B. B. SIMPSON. 2007. Molecular phylogenetic analysis of Commiphora (Burseraceae) yields insight on the evolution and historical biogeography of an "impossible" genus. Molecular phylogenetics and evolution 42: 62-79.

WILLIAMS L. O. AND J. CUATRECASAS. 1959. A critical new Bursera from Costa Rica. Tropical Woods 110: 30. 


\section{Appendix}

Appendix 1. Taxa sampled, secuence data and voucher information. $y=$ sequence to be uploaded to GenBank, $n=$ not available or DNA did not amplified for marker. Letters following GenBank sequences represent authorship: $\mathrm{a}=$ Weeks and Simpson (2004), $\mathrm{b}=$ Weeks et al. (2005), $\mathrm{c}=$ Weeks and Simpson (2007), $\mathrm{d}=$ Weeks and Tye (2009), e= Rosell et al. (2010).

\begin{tabular}{|c|c|c|c|c|c|c|c|}
\hline Taxa & ETS & PEPC & $\operatorname{trnH}^{p s b A-}$ & rps 16 intron & $\begin{array}{l}\text { rps16- } \\
\text { trnK }\end{array}$ & Voucher & Herbaria \\
\hline Boswellia sacra Flueck. & AY315092b & $\mathrm{n}$ & $\mathrm{n}$ & AY315000b & $\mathrm{n}$ & $\mathrm{n} / \mathrm{a}$ & $\mathrm{n} / \mathrm{a}$ \\
\hline $\begin{array}{l}\text { Bursera angustata } \text { Griseb. } \\
\text { Terminal A }\end{array}$ & $\mathrm{y}$ & $\mathrm{y}$ & $\mathrm{y}$ & $\mathrm{y}$ & $\mathrm{y}$ & Martínez-Habibe 2302 & RSA, NY, US \\
\hline $\begin{array}{l}\text { Bursera angustata } \text { Griseb. } \\
\text { Terminal B }\end{array}$ & $\mathrm{y}$ & $\mathrm{y}$ & $\mathrm{y}$ & $\mathrm{n}$ & $\mathrm{y}$ & Martínez-Habibe 2267 & RSA, NY, US \\
\hline $\begin{array}{l}\text { Bursera arborea (Rose) L. } \\
\text { Riley }\end{array}$ & GQ378006e & GQ377934e & GQ377870e & $\mathrm{n}$ & $\mathrm{n}$ & Rosell 16 & MEXU \\
\hline Bursera aromatica Proctor & $\mathrm{y}$ & $\mathrm{y}$ & $\mathrm{y}$ & $\mathrm{y}$ & $\mathrm{n}$ & Martínez-Habibe 2310 & \\
\hline $\begin{array}{l}\text { Bursera attenuata (Rose) L. } \\
\text { Riley }\end{array}$ & GQ378007e & GQ377935e & GQ377871e & $\mathrm{n}$ & $\mathrm{n}$ & R. Medina 3412 & MEXU \\
\hline Bursera biflora Standl. & AY315040b & GQ377998e & AY831896c & AY315001b & $\mathrm{n}$ & J.C. Montero sn & TEX \\
\hline Bursera brunea Urb. \& Ekman & $y$ & $\mathrm{n}$ & $\mathrm{n}$ & $\mathrm{n}$ & $\mathrm{n}$ & Correll 49953 & FTB \\
\hline Bursera cinerea Engl. & GQ378010 & GQ377938e & GQ377874e & $\mathrm{n}$ & $\mathrm{n}$ & Rosell 40 & MEXU \\
\hline $\begin{array}{l}\text { Bursera copallifera (Sessé \& } \\
\text { Moc. ex DC.) Bullock }\end{array}$ & AY315044b & GQ377999e & AY831897c & $\mathrm{n}$ & $\mathrm{y}$ & R. Medina 3975 & MEXU \\
\hline Bursera cuneata Engl. & AY315047b & GQ378000e & AY831898c & $\mathrm{n}$ & y & J.C. Montero 808 & MEXU \\
\hline Bursera discolor Rzed. & AY309307a & AY309364a & AY309390a & $\mathrm{n}$ & & R. Medina 4028 & MEXU \\
\hline $\begin{array}{l}\text { Bursera fagaroides (Kunth) } \\
\text { Engl }\end{array}$ & AY309310a & AY309365a & AY309391a & AY309283a & $\mathrm{n}$ & R. Medina 4227 & \\
\hline Bursera frenningae Correll & $\mathrm{y}$ & $\mathrm{y}$ & $\mathrm{y}$ & $\mathrm{y}$ & $\mathrm{y}$ & Martínez-Habibe 2359 & FTB \\
\hline $\begin{array}{l}\text { Bursera gibarensis } \text { M. C. } \\
\text { Martínez, Daly, \& J. Pérez }\end{array}$ & $\mathrm{y}$ & $\mathrm{y}$ & $\mathrm{y}$ & $\mathrm{y}$ & $\mathrm{y}$ & Martínez-Habibe 2307 & RSA, NY, US \\
\hline Bursera glauca Griseb. & $\mathrm{y}$ & y & y & y & $\mathrm{n}$ & Martínez-Habibe 2295 & RSA, NY, US \\
\hline Bursera aff. glauca & $\mathrm{y}$ & $\mathrm{y}$ & $\mathrm{y}$ & $\mathrm{y}$ & $\mathrm{y}$ & Martínez-Habibe 2237 & RSA, NY, US \\
\hline $\begin{array}{l}\text { Bursera gracilipes Urb. \& } \\
\text { Ekman }\end{array}$ & $\mathrm{y}$ & $\mathrm{n}$ & $\mathrm{n}$ & $\mathrm{n}$ & y & Martínez-Habibe 2291 & RSA, NY, US \\
\hline $\begin{array}{l}\text { Bursera grandifolia (Schltdl.) } \\
\text { Engl. }\end{array}$ & GQ378013e & GQ377941e & GQ377877e & $\mathrm{n}$ & $\mathrm{n}$ & Rosell 5 & MEXU \\
\hline $\begin{array}{l}\text { Bursera graveolens }(\mathrm{HBK}) \\
\text { Triana \& Planch. }\end{array}$ & GQ505948e & $\mathrm{n}$ & GQ505929e & GQ505922e & $\mathrm{n}$ & Tye 9452 & \\
\hline Bursera hindsiana Engl. & AY315050b & GQ378001e & AY831899c & $\mathrm{n}$ & $\mathrm{y}$ & J. Núñez-Farfán sn & MEXU \\
\hline $\begin{array}{l}\text { Bursera hollickii (Britt.) Fawc. } \\
\text { \& Rendle }\end{array}$ & $\mathrm{y}$ & $\mathrm{y}$ & $\mathrm{y}$ & $\mathrm{n}$ & $\mathrm{y}$ & Martínez-Habibe 2315 & RSA, NY, US \\
\hline $\begin{array}{l}\text { Bursera inaguensis Britt. } \\
\text { Terminal B }\end{array}$ & $\mathrm{y}$ & $\mathrm{y}$ & $\mathrm{y}$ & $\mathrm{y}$ & y & Martínez-Habibe 2222 & RSA, NY, US \\
\hline $\begin{array}{l}\text { Bursera inaguensis } \text { Britt. } \\
\text { Terminal A }\end{array}$ & $\mathrm{y}$ & $\mathrm{y}$ & $\mathrm{y}$ & $\mathrm{y}$ & $\mathrm{y}$ & Martínez-Habibe 2358 & FTB \\
\hline $\begin{array}{l}\text { Bursera instabilis McVaugh \& } \\
\text { Rzed. }\end{array}$ & GQ378020e & GQ377948e & GQ377884e & $\mathrm{n}$ & $\mathrm{n}$ & Rosell 13 & MEXU \\
\hline Bursera inversa Daly & $\mathrm{y}$ & $\mathrm{y}$ & $\mathrm{y}$ & $\mathrm{y}$ & $\mathrm{y}$ & Idárraga sn & $\mathrm{COL}$ \\
\hline Bursera itzae Lundell & GQ378022e & GQ377950e & GQ377886e & $\mathrm{n}$ & $\mathrm{n}$ & J.C. Montero 1029 & MEXU \\
\hline Bursera krusei Rzed. & GQ378024e & GQ377952e & GQ377888e & & $\mathrm{y}$ & R. Medina 4045 & MEXU \\
\hline Bursera lancifolia Engl. & AY309319c & AY309368c & AY309394c & & $\mathrm{n}$ & R. Medina 4007 & MEXU \\
\hline
\end{tabular}




\begin{tabular}{|c|c|c|c|c|c|c|c|}
\hline Taxa & ETS & PEPC & $\operatorname{trnH}^{p s b A-}$ & rps 16 intron & \begin{tabular}{|l|}
$\operatorname{rps} 16-$ \\
$\operatorname{trnK}$
\end{tabular} & Voucher & Herbaria \\
\hline $\begin{array}{l}\text { Bursera laurihuertae Rzed. \& } \\
\text { Calderón }\end{array}$ & GQ378025e & GQ377953e & GQ377889e & & $\mathrm{n}$ & Olson 1119 & MEXU \\
\hline $\begin{array}{l}\text { Bursera longipes (Rose) } \\
\text { Standl. }\end{array}$ & GQ378026e & GQ377954e & GQ377890e & $\mathrm{y}$ & $\mathrm{n}$ & Olson 1029 & MEXU \\
\hline $\begin{array}{l}\text { Bursera lunanii (Spreng.) C.D. } \\
\text { Adams \& Dandy ex Proctor }\end{array}$ & $\mathrm{y}$ & $\mathrm{y}$ & $\mathrm{y}$ & $\mathrm{n}$ & $\mathrm{y}$ & Martínez-Habibe 2313 & RSA, NY, US \\
\hline Bursera microphylla A. Gray & AY309328a & AY309370a & AY309396a & $\mathrm{gb}$ & $\mathrm{y}$ & J. Núñez-Farfán sn & MEXU \\
\hline Bursera morelensis Ramírez & AY309331a & AY309371a & AY309397a & $\mathrm{gb}$ & $\mathrm{n}$ & R. Medina 3971 & MEXU \\
\hline Bursera odorata Brandegee & AY309334a & AY309372a & AY309398a & $\mathrm{gb}$ & $\mathrm{n}$ & Weeks 00-X-9-2 & TEX \\
\hline $\begin{array}{l}\text { Bursera ovalifolia (Schltdl.) } \\
\text { Engl. }\end{array}$ & GQ378030e & GQ377958e & GQ377894e & $\mathrm{y}$ & $\mathrm{y}$ & Olson 1128 & MEXU \\
\hline $\begin{array}{l}\text { Bursera trinitensis R.O. } \\
\text { Williams }\end{array}$ & $\mathrm{y}$ & $\mathrm{y}$ & $\mathrm{y}$ & $\mathrm{y}$ & $\mathrm{y}$ & Martínez-Habibe 2288 & RSA, NY, US \\
\hline Bursera pereirae Daly & $\mathrm{y}$ & $\mathrm{n}$ & $\mathrm{n}$ & $\mathrm{n}$ & $\mathrm{n}$ & Daly s.n. & \\
\hline $\begin{array}{l}\text { Bursera permollis Standl. \& } \\
\text { Steyerm. }\end{array}$ & GQ378032e & GQ377960e & GQ377896e & $\mathrm{n}$ & $\mathrm{n}$ & J. Linares 7326 & MEXU \\
\hline $\begin{array}{l}\text { Bursera roseana } \text { Rzed., } \\
\text { Calderón \& Medina }\end{array}$ & GQ378035 & GQ377963 & GQ377899 & $\mathrm{n}$ & $\mathrm{n}$ & Rosell 25 & MEXU \\
\hline $\begin{array}{l}\text { Bursera sarukhanii Guevara \& } \\
\text { Rzed. }\end{array}$ & AY831900c & GQ378002e & AY831900c & $\mathrm{gb}$ & $\mathrm{y}$ & R. Medina 4246 & MEXU \\
\hline Bursera schlechtendalii Engl. & AY309325a & AY309377a & AY309400a & $\mathrm{gb}$ & $\mathrm{n}$ & Olson 1050 & INB \\
\hline Bursera shaferi Urb. & $\mathrm{Y}$ & $\mathrm{y}$ & $\mathrm{y}$ & $\mathrm{n}$ & $\mathrm{y}$ & Martínez-Habibe 2240 & RSA, NY, US \\
\hline Bursera simaruba (L.) Sarg & GQ378047e & GQ377975e & GQ377911e & $\mathrm{n}$ & $\mathrm{n}$ & Rosell 45 & MEXU \\
\hline $\begin{array}{l}\text { Bursera spinescens Urb. \& } \\
\text { Ekman }\end{array}$ & 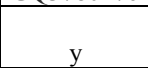 & ( & $\mathrm{y}$ & $\mathrm{n}$ & $\mathrm{y}$ & Martínez-Habibe 2284 & RSA, NY, US \\
\hline $\begin{array}{l}\text { Bursera standleyana } \mathrm{L} . \\
\text { O.Williams \& Cuatrec. }\end{array}$ & $\mathrm{y}$ & $\mathrm{y}$ & & & $\mathrm{y}$ & Aguilar sn & * \\
\hline Bursera tecomaca Standl. & $\mathrm{y}$ & AY309362a & AY309409a & $\mathrm{n}$ & $\mathrm{y}$ & R. Medina 4512 & MEXU \\
\hline $\begin{array}{l}\text { Bursera tonkinensis } \\
\text { Guillaumin }\end{array}$ & $\mathrm{y}$ & $\mathrm{y}$ & $\mathrm{n}$ & $\mathrm{n}$ & $\mathrm{n}$ & Daly sn & NY \\
\hline $\begin{array}{l}\text { Commiphora africana (A. } \\
\text { Rich.) Engl. }\end{array}$ & AY831869c & GQ378003e & AY831901c & AY831941c & $\mathrm{y}$ & Weeks 02-XII-09-03 & TEX \\
\hline $\begin{array}{l}\text { Commiphora aprevalii } \\
\text { Guillaumin }\end{array}$ & AY831870e & $\mathrm{n}$ & AY831903e & AY831942e & $\mathrm{y}$ & Phillipson 2563 & MO \\
\hline Commiphora campestris Engl. & AY831873c & GQ378004e & AY831906c & AY831945.1 & $\mathrm{y}$ & Weeks 00-VI-24-3 & TEX \\
\hline Commiphora edulis Engl. & AY831871e & $\mathrm{n}$ & AY831908e & AY831943e & $\mathrm{y}$ & Robertson 4083 & MO \\
\hline $\begin{array}{l}\text { Commiphora franciscana } \\
\text { Capuron }\end{array}$ & AY315065e & $\mathrm{n}$ & AY831911e & AY315014e & $\mathrm{y}$ & $\mathrm{n} / \mathrm{a}$ & $\mathrm{n} / \mathrm{a}$ \\
\hline Commiphora grandifolia Engl. & AY831876e & $\mathrm{n}$ & AY831912e & AY831948e & $\mathrm{y}$ & Phillipson et al. 3483 & MO \\
\hline $\begin{array}{l}\text { Commiphora guillaumini } \mathrm{H} \text {. } \\
\text { Perrier }\end{array}$ & AY831877e & $\mathrm{n}$ & AY831913e & AY831949e & $\mathrm{y}$ & Weeks 00-VIII-18-1 & TEX \\
\hline $\begin{array}{l}\text { Commiphora leptophloeos } \\
\text { (Mart.) J.B.Gillett }\end{array}$ & AY315071c & $\mathrm{n}$ & AY831918c & AY315016c & $\mathrm{y}$ & $\mathrm{n} / \mathrm{a}$ & $\mathrm{n} / \mathrm{a}$ \\
\hline $\begin{array}{l}\text { Commiphora wightii (Arn.) } \\
\text { Bhandari }\end{array}$ & AY315083c & $\mathrm{n}$ & AY831936c & AY315020c & $\mathrm{y}$ & $\mathrm{n} / \mathrm{a}$ & $\mathrm{n} / \mathrm{a}$ \\
\hline Canarium pilosum A.W.Benn & AY315118c & $\mathrm{n}$ & AY635378c & AY315008c & $\mathrm{n}$ & Bogler s.n. & TEX \\
\hline Protium_copal Engl. & AY964612e & $\mathrm{n}$ & AY831939c & $\mathrm{AY} 315027 \mathrm{c}$ & $\mathrm{n}$ & $\begin{array}{l}\text { Daly sn, Killeen et al. } \\
3136\end{array}$ & $\mathrm{NY}, \mathrm{MO}$ \\
\hline Santiria griffithii Engl. & AY315132c & $\mathrm{n}$ & AY831940c & AY315031c & $\mathrm{n}$ & $\mathrm{n} / \mathrm{a}$ & $\mathrm{n} / \mathrm{a}$ \\
\hline
\end{tabular}

